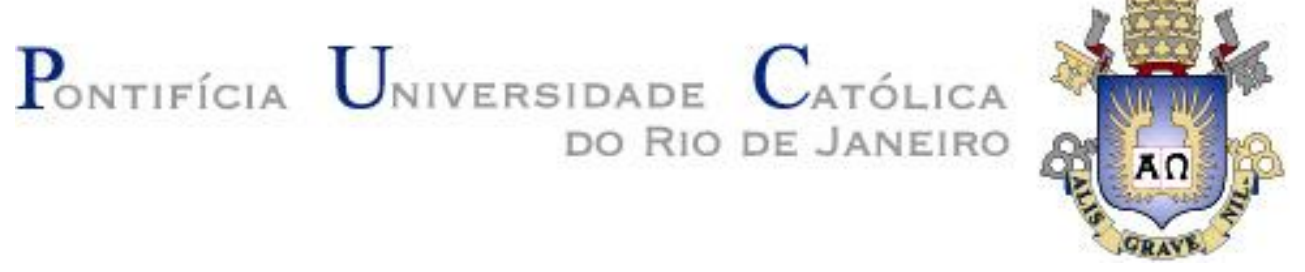

Jeane Rodrigues Lucena Niemeyer

\title{
Ética na liderança e LMX (Leader Member Exchange): uma análise sobre o desempenho individual
}

Dissertação de Mestrado

Dissertação apresentada como requisito parcial para obtenção do título de Mestre pelo Programa de PósGraduação em Administração de Empresas da PUCRio.

Orientadora: Profa. Flávia de Souza Costa Neves Cavazotte

Rio de Janeiro

Setembro de 2013 
Jeane Rodrigues Lucena Niemeyer

Ética na liderança e LMX (Leader Member Exchange): uma análise sobre o desempenho individual

Dissertação apresentada como requisito parcial para obtenção do título de Mestre pelo Programa de PósGraduação em Administração de Empresas da PUC-Rio. Aprovada pela Comissão Examinadora abaixo assinada.

Profa. Flávia de Souza Costa Neves Cavazotte Orientadora Departamento de Administração - PUC-Rio

Profa. Ana Heloísa da Costa Lemos Departamento de Administração - PUC-Rio

Profa. Lucia Barbosa de Oliveira Departamento de Administração - Ibmec

Profa. . Mônica Herz Vice-Decana de Pós-Graduação do CCS - PUC-Rio

Rio de Janeiro, 05 de Setembro de 2013. 
Todos os direitos reservados. É proibida a reprodução total ou parcial do trabalho sem autorização da universidade, da autora e da orientadora.

\section{Jeane Rodrigues Lucena Niemeyer}

Graduou-se em Psicologia na Universidade Federal do Rio de Janeiro em 2008. Cursou Pós-Graduação Lato Sensu em Recursos Humanos na Fundação Coppead - UFRJ em 2008. Atuou em empresas nacionais e multinacionais. Atualmente, é Pesquisadora e Consultora das áreas de Liderança e Comportamento Organizacional.

Ficha Catalográfica

Niemeyer, Jeane Rodrigues Lucena

Ética na liderança e LMX (Leader Member Exchange): uma análise sobre o desempenho individual / Jeane Rodrigues Lucena Niemeyer; orientadora: Flávia de Souza Costa Neves Cavazotte. - 2013.

102 f. : il. ; $30 \mathrm{~cm}$

Dissertação (mestrado)-Pontifícia Universidade Católica do Rio de Janeiro, Departamento de Administração, 2013.

Inclui bibliografia

1. Administração - Teses. 2. Liderança ética.3. LMX.4. Desempenho individual.5. Comprometimento com a meta. 6. Cidadania organizacional. I. Cavazotte, Flávia de Souza Costa Neves. II. Pontifícia Universidade Católica do Rio de Janeiro. Departamento de Administração. III. Título.

CDD: 658 
Aos meus pais, meu filho Pedro e minha avó Ana (in memoriam $\boldsymbol{\vee}$ ), que me ensinaram o essencial à vida, o que é o amor. 


\section{Agradecimentos}

Primeiramente, agradeço a Deus, pela vida e pela possibilidade de realizar essa mudança na minha carreira, fonte de satisfação e realização.

Aos meus pais, o que sou hoje e o que serei no futuro, é fruto de todo amor e dedicação de uma vida inteira. Obrigada pelo incentivo e por serem minha fortaleza e refúgio.

Ao meu marido e parceiro Renato, pelo amor, apoio, compreensão e por toda a cumplicidade na realização deste sonho.

Ao meu filho Pedro, grande motivador deste projeto, que teve dedicação exclusiva, embora "compartilhada" com seus cuidados nos primeiros dois anos de sua vida.

À minha família e amigos, que são irmãos que a vida me concedeu. Ter vocês ao meu lado é sinônimo de alegria e felicidade! É saber que, para sempre, tenho com quem dividir os prazeres e desprazeres da vida, que serão atenuados simplesmente pelo fato de tê-los comigo.

À Professora Doutora Flávia Cavazotte, pela verdadeira parceria. Orientação, apoio, estímulo e conversas fizeram essa trajetória mais prazerosa e desafiadora. Trabalhar com você é fonte de inspiração à carreira docente e ao trabalho com verdadeira atribuição de sentido à vida.

Aos professores da PUC, por todo aprendizado e troca de conhecimento, de fundamental contribuição à minha formação. Agradeço, especialmente, a Ana Heloísa e Lucia Barbosa, pela participação neste momento decisivo. E ainda aos funcionários Teresa e Fábio, por toda colaboração atenciosa, sempre que necessário. 
Agradeço também aos funcionários da empresa participantes desta pesquisa e, especialmente, à gestora da área, pela possibilidade de realização deste trabalho e, principalmente por ser exemplo de profissional e de uma liderança inspiradora.

Ao CNPq e à PUC-Rio, pelos auxílios concedidos, de fundamental importância para a realização deste trabalho.

A todas as pessoas, que na vida acadêmica ou profissional contribuiram de alguma forma para a concretização de mais esta etapa, o meu sincero muito obrigada! 


\section{Resumo}

Niemeyer, Jeane Rodrigues Lucena; Cavazotte, Flávia de Souza Costa Neves. Ética na liderança e LMX (Leader Member Exchange): uma análise sobre o desempenho individual. Rio de Janeiro, 2013. 102 p. Dissertação de Mestrado - Departamento de Administração, Pontifícia Universidade Católica do Rio de Janeiro.

Em um contexto marcado por crises políticas, sociais e econômicas, correntes teóricas acerca do tema Liderança assumem nova configuração ressaltando a relevância da ética e moralidade no processo de liderar. Diante do clima de medo e incerteza gerado por essas adversidades (NORTHOUSE, 2010), o grande desafio dos últimos tempos parece ser restabelecer a confiança, esperança e otimismo (AVOLIO e GARDNER, 2005). Este estudo analisou a influência da liderança ética sobre os funcionários no que diz respeito ao desempenho, comprometimento com a meta e cidadania organizacional através da qualidade da relação de troca entre o líder e seus subordinados (LMX). A pesquisa foi realizada em uma empresa multinacional de telecomunicações, com uma amostra de 161 vendedores e 15 gerentes de lojas. Os resultados indicam que há uma relação significativa da ética do líder com a qualidade do relacionamento com seus seguidores e consequente desempenho individual.

\section{Palavras chave}

Liderança ética; LMX; desempenho individual; comprometimento com a meta; cidadania organizacional. 


\section{Abstract}

Niemeyer, Jeane Rodrigues Lucena; Cavazotte, Flávia de Souza Costa Neves (Advisor). Ethical leadership and LMX (Leader Member Exchange): An analysis of individual performance. Rio de Janeiro, 2013. 102 p. MSc. Dissertation - Departamento de Administração, Pontifícia Universidade Católica do Rio de Janeiro.

In a context marked by political, social and economic crisis, theoretical currents concerning the subject leadership assume new configurations standing out the relevance of the ethics and morality in the leadership process. Given the climate of fear and uncertainty generated bythese adversities (NORTHOUSE, 2010), the great challenge of the present tiem seems to be to reestablish confidence, hope and optimism (AVOLIO and GARDNER, 2005). This study analyzed the influence of ethical leadership on the performance of the workers, goal commitment and organizational citizenship through the quality of the relationship (LMX) established between the leader and his subordinate. The research was carried through in a multinational telecommunications company, with a sample of 161 salesmen and 15 store managers. The results indicate a significant relationship between the ethics of the leader and the quality of the relationship they have with their followers and consequent individual performance.

\section{Keywords}

Ethical Leadership; LMX; individual performance; goal commitment; organizational citizenship. 


\section{Sumário}

1 INTRODUÇÃO 15

$\begin{array}{lr}\text { 1.1. Problema de pesquisa } & 17\end{array}$

$\begin{array}{ll}\text { 1.2. Objetivos } & 19\end{array}$

$\begin{array}{ll}\text { 1.3. Relevância do Estudo } & 19\end{array}$

1.4. Estrutura do trabalho 20

2 REFERENCIAL TEÓRICO 22

2.1. Liderança $\quad 22$

2.1.1. A Ética e autenticidade do Líder 24

$\begin{array}{ll}\text { 2.1.2. Liderança ética } & 28\end{array}$

2.2. LMX (Leader Member Exchange) 32

2.2.1. Liderança ética e LMX 33

2.3. Díade Líder-seguidor e LMX 34

2.3.1. SOA - Self Other Agreement 35

2.3.2. Self-Other Agreement (SOA) e LMX 37

2.3.3. Fit-Congruência Líder e seguidor 38

2.3.4. Congruência ética Líder-Seguidor (FIT) e LMX 40

2.4. Desempenho Individual $\quad 40$

2.4.1. LMX (Leader Member Exchange) e Desempenho 42

2.5. Comportamento de cidadania organizacional (CCO) 44

2.5.1. Liderança ética e Comportamento de cidadania organizacional 47

2.5.2. LMX (Leader Member Exchange) e Comportamento de cidadania organizacional (CCO) 48

2.6. Comprometimento com a meta 50

2.6.1. LMX e Comprometimento com a meta 51 
3. MODELO DA PESQUISA

4. METODOLOGIA

4.1. Universo e Amostra $\quad 54$

4.2. Coleta de dados 54

4.3. Medidas e Instrumentos utilizados 55

5. ANÁLISE DOS DADOS E RESULTADOS 59

5.1. Caracterização da amostra 59

5.2. Análise descritiva 60

$\begin{array}{ll}\text { 5.3. Análise de hipóteses } & 61\end{array}$

5.3.1. Análise FIT e SOA 65

6. DISCUSSÃO 70

6.1. Modelo Alternativo 73

7. CONCLUSÕES E RECOMENDAÇÕES

$\begin{array}{ll}\text { 7.1. Conclusões e Implicações } & 74\end{array}$

$\begin{array}{ll}\text { 7.2. Implicações gerenciais } & 76\end{array}$

$\begin{array}{ll}\text { 7.3. Limitações e sugestões para futuras pesquisas } & 77\end{array}$

8. REFERÊNCIAS BIBLIOGRÁFICAS 79

9. APÊNDICE 89 
9.1. Apêndice A 89

9.2. Apêndice B 96 


\section{Lista de figuras}

Figura 1: Modelo da Pesquisa 38

Figura 2: Modelo da pesquisa adaptado 59 


\section{Lista de tabelas}

Tabela 1: Síntese do modelo - Yammarino \& Atwater (1997) 22

Tabela 2: FIT e SOA 25

Tabela 3: Dados demográficos 45

Tabela 4: Médias, Desvios-Padrão, Correlações e Alfa de Cronbach 46

Tabela 5: Regressão Múltipla - Preditores de LMX (perspectiva do

subordinado) 48

Tabela 6: Regressão Múltipla - Preditores Desempenho (sob ótica do líder) 49

Tabela 7: Regressão Múltipla - Preditores Cidadania organizacional individual 50

Tabela 8: Regressão Múltipla - Preditores Comprometimento com a meta 51

Tabela 9: Regressão Múltipla - Preditores de LMX (SOA e FIT) 53

Tabela 10: Regressão preditores LMX - FIT 54

Tabela 11: Regressão preditores LMX - SOA 55 
“...uma vida cheia de sentido fora do trabalho supõe uma vida dotada de sentido dentro do trabalho. Não é possível compatibilizar trabalho assalariado, fetichizado e estranhado com tempo livre. Uma vida desprovida de sentido no trabalho é incompativel com uma vida cheia de sentido fora do trabalho. Em alguma medida, a esfera fora do trabalho estará maculada pela desefetivação que se dá no interior da vida laborativa." (Ricardo Antunes) 


\section{1 Introdução}

No decorrer da história da Administração, as diferentes áreas que compõem esta ciência têm contribuído com a pesquisa de um dos seus principais objetos de estudo: a eficiência das organizações. Acerca do tema, são encontrados na literatura diferentes campos de investigação que concentram seus esforços no aprofundamento das estratégias de diferenciação em mercados exponencialmente mais competitivos. Na incessante busca pelo sucesso organizacional, há a necessidade de lidar com grandes desafios, como a política, a globalização, a tecnologia, as condições socio-econômicas, novas e constantes ameaças competitivas, entre outros (PETERSON e HICKS, 1995).

Neste contexto, é preciso reconhecer que quase todos os recursos responsáveis pelo sucesso organizacional, como a tecnologia, estrutura financeira ou estratégia competitiva, podem ser facilmente imitáveis em um curto espaço de tempo. Assim, a fim de alcançar diferenciação nos resultados organizacionais, deve-se ressaltar o investimento no relacionamento do funcionário com a organização (PFEFFER,1998). Ainda no início do século passado, Drucker (1909) augumentou que tornar os recursos humanos produtivos seria a única forma de adquirir vantagem competitiva, de modo que a organização que não soubesse fazê-lo poderia ter desvantagem competitiva.

Diante deste desafio, parece ser pertinente a questão: de que forma as relações humanas podem contribuir para a efetividade organizacional? Argyris (1960) acredita no potencial das referidas relações através do envolvimento, engajamento e clima de colaboração entre seus membros. Neste âmbito, os estudos da liderança com cunho estratégico têm crescido nos últimos anos com o objetivo de responder o verdadeiro poder de influência dos líderes no trabalho, ou seja, no desempenho de seus seguidores (YUKL, 2008). 
As teorias da liderança baseadas na ética, autenticidade ou moralidade do líder desenvolveram-se como uma espécie de "resposta" aos acontecimentos contemporâneos que englobam terrorismo, crescente e conflituosa discussão sobre sustentabilidade, escândalos corporativos e corrupção. Os acontecimentos que povoam esse cenário são diversos. No âmbito internacional, a tragédia em Nova York no dia 11 de setembro, exemplo de ataque liderado por uma organização terrorista; nacionalmente, o mensalão, crime político recente que teve maior número de indiciados na história brasileira. É a partir da aparente crise ética que envolve a política, questões de corrupção na sociedade e no governo que o debate sobre ética tem sido amplamente discutido em ciências como a filosofia e a administração. Um exemplo da tentativa de sistematizar e orientar a conduta da sociedade está nos códigos de ética que regulamentam grande parte das profissões existentes (MARCONDES, 2007).

Avolio e Gardner (2005) acreditam que o grande desafio dos últimos tempos é restabelecer a confiança, a esperança e o otimismo. Diante do clima de medo e incerteza gerado pelas crises, as pessoas se sentem apreensivas e inseguras e clamam por uma liderança na qual possam confiar, com líderes honestos e bons (NORTHOUSE, 2010).

É neste cenário que o desenvolvimento das abordagens de liderança ética e autêntica contribuem para o avanço da teoria de liderança. A importância do estudo dessas correntes teóricas não está apenas na investigação da conduta moral do líder, mas nos efeitos de suas ações: relações estabelecidas com terceiros e a influência na atuação dos seguidores através da comunicação bidirecional (BROWN, TREVIÑO e HARRISON, 2005). Para compreender a efetividade da liderança, é necessário desvendar os efeitos dos líderes nos seguidores, ou seja, debruçar-se sobre teorias de processos psicológicos que transformem o comportamento do líder na ação de um seguidor (DAAN VAN KNIPPENBERG, BARBARA VAN KNIPPENBERG, CREMER, HOGG; 2004)

$\mathrm{Na}$ teoria de liderança ética, a instância social assume um papel extremamente relevante e esclarecedor. A partir do relacionamento estabelecido entre gestor e funcionários em um ambiente corporativo, a aprendizagem acerca dos padrões éticos pode ocorrer de forma direta, a partir da comunicação, recompensas ou punições, e indiretamente, através de observações (BROWN e 
TREVIÑO, 2006). Essa abordagem apresenta semelhanças com a teoria de liderança denominada Leader Member Exchange - LMX (GRAEN e UHL-BIEN, 1995), que tem como foco a interação, o relacionamento e os desdobramentos de líderes e seguidores, principalmente no que diz respeito às ações que norteiam os resultados dos liderados comocomportamentos e atitudes.

A visão que os funcionários estabelecem sobre seus gestores no que diz respeito aos seus valores, crenças e comportamentos influencia suas próprias atitudes nas organizações. De acordo com Ciulla (2004), é importante que os líderes tenham consistência moral e isso significa basear suas ações nos seus valores. Caso isto não aconteça, eles perdem a confiança de seus liderados e stakeholders.

\section{1.}

\section{Problema de pesquisa}

Embora estudos teóricos relevantes tenham concentrado esforços em investigar aspossíveis consequências da relação de troca estabelecida entre líder e equipe (GRAEN e UHL-BIEN, 1995; LIDEN, WAYNE e STILWELL, 1993; COGLISER, SCHRIESHEIM, SCANDURA e GARDNER, 2009), ainda existem lacunas na literatura no que concerne aos estudos dos antecedentes dessa relação. De forma a ampliar este debate, o presente estudo visa a abordagem desta teoria de troca entre líder e liderados e seus possíveis antecedentes.

O desenvolvimento da teoria de liderança ética enfatiza o caráter de influência dos líderes sobre seus seguidores. Através de sua conduta moral, o líder seria uma espécie de modelo, que pode significar influência nas atitudes de seus subordinados (BROWN, TREVIÑO e HARRISON, 2005). Estudos recentes têm demonstrado efeito positivo da liderança ética sobre o comportamento dos seguidores (PICCOLO, GREENBAUM, DEN HARTOG e FOLGER, 2010; WALUMBWA, MAYER, WANG, WANG, WORKMAN e CHRISTENSEN, 2011).

Uma abordagem consensual acerca da teoria de liderança ética é a influência que a mesma pode proporcionar ao relacionamento de líderes e seus subordinados. Uma vez que líderes são considerados éticos por seus seguidores, apresentam, sob a perspectiva de suas equipes, maior senso de justiça, com 
atitudes menos egoístas e mais altruístas. Como consequência, pesquisas empíricas têm demonstrado influência positiva da liderença ética na relação de LMX (TUMASJAN, STROBEL e WELPE, 2011; MASHUD et al., 2010).

A partir da relevância teórica da liderança ética no que concerne ao relacionamento estabelecido entre líderes e seus seguidores, o presente trabalho visa explorar a variável ética na liderança a partir de diferentes perspectivas. Além do olhar do funcionário sobre a ética de seu líder, leva-se em consideração o olhar do próprio líder acerca de sua ética no trabalho. Utiliza-se, assim, o alinhamento da percepção da avaliação interpessoal, self-other rating agreement (ATWATER, WANG, SMITHER e FLEENOR, 2009; FLEENOR, MCCAULEY e BRUTUS, 1996; OSTROFF, ATWATER, e FEINBERG, 2004; YAMMARINO e ATWATER, 1993). Este modelo é traduzido pelo grau de concordância da autoavaliação do líder com as avaliações de seus subordinados.

Além disso, considerando que, consensualmente, a liderança é um processo que envolve líder e seguidor (NORTHOUSE, 2010), as perspectivas dos seguidores são relevantes para oprocesso de liderar. No modelo deste trabalho a ética do seguidor é levada em consideração, dada a relevância teórica presente na literatura acerca da investigação da aproximação dos valores e aspectos da personalidade do líder e seus seguidores. Tal aproximação tem apontado para o desenvolvimento da relação de LMX com impacto positivo em atitudes relacionadas ao trabalho (KEMELGOR, 1982; ERDOGAN, KRAIMER e LIDEN, 2004). Desta forma, será utilizado o construto denominado congruência ou fit, em inglês (KRISTOF-BROWN, ZIMMERMAN e JONHSON, 2005).

Desta maneira, a presente pesquisa visa responder as seguintes perguntas:

O alinhamento da ética de líderes e seguidores tem impacto na qualidade da relação entre eles (LMX - Leader Member Exchange)?

O alinhamento da avaliação do subordinado em relação à ética do líder e a autoavaliação ética do líder tem impacto no relacionamento estabelecido entre ambos?

A percepção de uma liderança ética sob a ótica dos seguidores tem impacto sobre o comportamento no trabalho no que tange ao comportamento de cidadania organizacional? 
E ainda:

O LMX tem impacto no desempenho individual, comportamento de cidadania organizacional e comprometimento com a meta dos subordinados?

\section{2.}

\section{Objetivos}

Alguns objetivos intermediários são listados a seguir:

- Investigar se a ética na liderança, representada pelo alinhamento entre a auto-avaliação do líder e a avaliação do subordinado, está relacionada com a qualidade da relação entre líderes e subordinados.

- Verificar se a aproximação da ética do líder e seus liderados também atua como precedente de uma melhor relação entre os envolvidos.

- Apurar se a ética da liderança, apenas sob o olhar dos subordinados, tem impacto sobre a relação entre líder-liderado.

- Investigar o reflexo da relação de LMX (Leader Member Exchange) no desempenho individual, cidadania organizacional e comprometimento com a meta.

\section{3.}

\section{Relevância do Estudo}

O encontro anual mais importante da Administração que reúne estudantes, pesquisadores, professores, teóricos e líderes do mundo inteiro. O Academy of Management tem como visão "inspirar e possibilitar um mundo melhor através do estudo e ensino sobre gestão e organizações." O tema do encontro no ano de 2013 foi "Capitalismo em questão", abordado sob a perspectiva das recentes crises e movimentos de protestos econômicos, sociais e ambientais ao redor do mundo (ACADEMY OF MANAGEMENT, 2013).

Os recentes acontecimentos contemporâneos envolvendo terrorismo, escândalos corporativos e corrupção têm inspirado o aprofundamento da ética e o desenvolvimento de uma teoria denominada liderança ética. A associação dos líderes considerados éticos e seus efeitos positivos nas atitudes dos seus subordinados (PICCOLO et al., 2010; WALUMBWA et al., 2009) tem ampliado o debate acadêmico e fomentado crescentes pesquisas empíricas sobre o tema. 
Neste sentido, a presente pesquisa denota sua relevância na medida em que nos ajuda a compreender a liderança ética como antecedente do relacionamento líder-seguidor e suas posssíveis consequências, elucidadas nesta análise pelo desempenho individual, comportamento de cidadania organizacional e comprometimento com a meta.

Os construtos analisados neste trabalho denotam contribuição empírica à literatura sobre liderança ética, que é predominantemente constituida por pesquisas teóricas. Se as hipóteses desse estudo forem corroboradas, para as organizações há especial relevância com implicações diretamente relacionadas à liderança e à maneira de gerenciar pessoas e indiretamente relacionadas aos resultados organizacionais. Considerar a dimensão ética na seleção e desenvolvimento de novos gestores pode significar melhor relacionamento entre líderes e seguidores, maior colaboração individual entre membros da equipe, além do nível de comprometimento com metas e desempenho superiores.

\section{4 . \\ Estrutura do trabalho}

O presente trabalho está dividido em sete capítulos: o primeiro trata da introdução na qual é apresentado o tema de pesquisa, sua inclusão teórica, os objetivos e relevância à comunidade acadêmica e organizacional.

No segundo capítulo, é estruturada uma revisão de literatura envolvendo os principais assuntos que fundamentam teoricamente o estudo: liderança ética, LMX, desempenho, comprometimento com a meta e cidadania organizacional.

Em seguida, no terceiro capítulo, apresenta-se o modelo teórico e as hipóteses de pesquisa que o compõem.

O quarto capítulo é composto pela metodologia utilizada, apresentada com a seguinte composição: definição do tipo de pesquisa, elucidação do universo e amostra utilizada, coleta de dados, medidas e instrumentos utilizados.

Os resultados do estudo são apresentados no quinto capítulo, onde a amostra também é caracterizada. Há a realização de teste do modelo proposto através da verificação das hipóteses da pesquisa e discussão das relações observadas entre os construtos estudados.

É no capítulo seis que os resultados apresentados são discutidos e, por fim, o capítulo sete apresenta a conclusão do trabalho com uma síntese dos resultados, 
as principais conclusões, contribuições e implicações práticas e teóricas. Também são descritas as limitações do estudo e sugestões para novas pesquisas. 


\section{2 \\ Referencial Teórico}

Pfeffer (1998) afirma que colocar as pessoas em 'primeiro lugar' significa articular indicadores, valores, metas e terminologias organizacionais através de posições de liderançae práticas específicas. A viabilidade é possível por meio do alinhamento das dimensões cultural, estratégica e de pessoas em prol dos objetivos organizacionais.

O líder simboliza, portanto, uma espécie de elo entre a organização e seus funcionários. A maneira através da qual líderes identificam e pensam condições competitivas, oportunidades de negócios e gestão de pessoas pode influenciar o desempenho das organizações (YUKL, 2008).

\section{1 . \\ Liderança}

A palavra liderança provém da língua inglesa, a expressão "to lead" significa conduzir, guiar, dirigir, comandar, persuadir, encaminhar, encabeçar, chefiar. Embora a tradução seja clara e direta, a pesquisa sobre o tema liderança é complexa e a comunidade acadêmica é envolvida por várias correntes teóricas, ora divergentes, ora convergentes ou com visões complementares.

Segundo Kotter (1990), a liderança estaria relacionada ao gerenciamento da mudança através de uma visão de futuro, objetivando o engajamento das pessoas através de inspiração e clara comunicação para o alcance dos resultados. Dessa maneira, a fim de conduzir e influenciar pessoas, o líder precisa conhecêlas, saber lidar com suas emoções e desejos, fomentando assim a obtenção dos resultados propostos (KOTTER,1990).

Embora seja fácil identificar a liderança na prática, defini-la precisamente é uma tarefa desafiadora. Antonakis e Day (2011) afirmam que grande parte dos teóricos concorda com a definição de liderança no que concerne em dois princípios básicos: (1) Um processo de influência que ocorre entre líder e 
seguidores e que tem um resultado como produto final; (2) Processo de influência caracterizado pelos comportamentos e características do líder, a percepção dos seguidores sobre o líder e o contex to em que esse processo ocorre.

No início do século XX, a partir da concepção de que a liderança seria nata, as teorias dos traços apontavam para a tentativa de explicitar as características da personalidade que diferenciavam os líderes dos não líderes. Alguns traços do então considerado líder seriam: autoconfiança, inteligência, sociabilidade, integridade e determinação (NORTHOUSE, 2010). Essa abordagem preconiza que os líderes possuidores de determinados traços de personalidade podem ser mais eficazes uma vez que isso caracteriza a forma como o líder se comporta em relação a sua equipe.

Paulatinamente, as limitações dessa vertente favoreceram o surgimento de estudos nos quais era perceptível a consideração de aspectos interacionais da relação entre líder e seguidores, assim como as contingências que influenciariam o processo de liderança (ANTONAKIS e DAY, 2011; NORTHOUSE, 2010). É neste cenário que surgem as teorias comportamentais, com o objetivo de estudar o impacto do comportamento dos líderes em um desempenho eficaz.

Ao considerar diferentes aspectos do processo de liderança que não se limitariam à figura do líder, suas características ou estilos comportamentais de liderança, os seguidores e o contexto assumem uma posição de destaque e relevância. A partir dos estudos realizados, observa-se a não indicação de um estilo de liderança universal que seja adequado a toda e qualquer situação (ANTONAKIS e DAY, 2011; HERSEY e BLANCHARD, 1986). Portanto, a questão que é apresentada é: qual o estilo mais eficaz para uma determinada situação?

As situações nas quais se observa o processo de liderança emergir levam em consideração os seguidores. O comportamento a ser adotado pelo líder, por exemplo, dependerá do nível de maturidade das pessoas que deseja influenciar (SANT`ANNA, 2010). Assim, são observadas relevantes discussões sob a ótica da participação dos seguidores no processo definindo e modificando o contexto, cedendo espaço para a escola de liderança relacional, abordagem que se concentra no relacionamento e troca entre líderes e liderados (LMX). 
Hughes, Ginnett e Curphy (2005) chamam atenção para a indissolúvel relação dos seguidores da liderança: o líder apenas consegue exercer sua liderança se os seguidores o legitimarem como tal. No início do século XX, os seguidores eram considerados submissos e passivos, enquanto líderes exerciam o papel de supervisores, diretivos e ativos. Em seguida, a liderança é considerada como um processo não estático, seguidores e líderes se influenciam mutuamente. Logo, um indivíduo pode ser líder em uma organização e, em outra, assumir o papel de seguidor; o que mais uma vez, reforça o caráter dinâmico da liderança (ROST, 1991).

As teorias situacionais e contingenciais defendem que o sucesso do líder e estilo de liderança assumido dependem da forma em que ele se relaciona com a situação que lhe é apresentada. Segundo Stoner e Freeman (1985), as principais variáveis identificadas no processo são: a personalidade e experiência passada do líder, as características, expectativas e o comportamento dos subordinados; as exigências do trabalho; as políticas e o clima da organização e as expectativas e comportamentos dos colegas. Portanto, não existe um único estilo ou característica da liderança válida para toda e qualquer situação uma vez que esta é resultado de uma combinação de diversos fatores.

\subsection{1.}

\section{A Ética e autenticidade do Líder}

Em um mundo reconhecidamente mais complexo são desvendados escândalos frequentes envolvendo CEOs gananciosos, empresas que comercializam a vida do consumidor visando o lucro e, ainda, líderes políticos corruptos (GEORGE, 2007). Neste contexto, a lealdade que seguidores desenvolvem por seus líderes e os desdobramentos desse processo para as organizações se tornam importantes objetos de estudo. Um desafio da liderança na atualidade, como salientam Metcalf e Benn (2012), é o engajamento das pessoas no complexo processo de adaptação dos sistemas e dinâmicas organizacionais relacionadas à sustentabilidade.

Nota-se que a liderança tem sido considerada como um processo inerentemente moral, no qual há uma idealização da figura do líder. Enquanto a figura do gestor estaria focada no desempenho da organização, de forma a 
administrar e coordenar pessoas e recursos, a representação do líder estaria relacionada ao caráter simbólico da esperança em controlar o destino (KOCIATKIEWICZ e KOSTERA,2012).

Os termos ética e moralidade têm sido utilizados na literatura a partir de diferentes conceitos e significados. A palavra "ética", em inglês ethics, é originária das palavras gregas ethikos, que significa pertencer ao costume, e ethos, que se refere ao caráter. A palavra "moralidade", em inglês morality, tem sua origem na palavra latina mores, que se refere ao caráter, costume e hábito. Embora alguns filósofos atribuam sentidos diferentes às duas expressões, nos estudos sobre liderança as duas palavras são amplamente utilizadas. Ser moral ou ético é comumente entendido como ser comprometido com ações corretas (RHODE, 2006) ou agir de maneira a produzir resultados de maneira justa (SCHULMAN, 2002) ou, ainda, “ética envolve o que é certo e errado, bom e mau, o que devemos e o que não devemos fazer como seres humanos, membros de um grupo ou sociedade nos diferentes papéis que assumimos" (CIULLA, 2004). Utilizando-se esta premissa, as duas expressões, "moral" e "ética", serão consideradas sinônimas nesta pesquisa.

O conceito de moralidade na Filosofia despertou o interesse de filósofos considerados importantes na comunidade acadêmica, motivo pelo qual o tema reserva interessantes discussões. Nietzche foi um dos pensadores que se destacaram pela crítica postura adotada em relação a obras anteriormente publicadas sobre a temática. A argumentação dele era baseada na não universalização dos conceitos e valores morais tradicionais, uma vez que a criação dos mesmos se concentrava em um determinado momento histórico, em uma sociedade específica; portanto, atentendo a interesses e propósitos contextualmente estabelecidos (MARCONDES, 2007).

De uma forma abrangente, Marcondes (2007, p.9) elucida que a ideia central dos autores sobre ética era: "a determinação do que é certo ou errado, bom ou mau, permitido ou proibido, de acordo com um conjunto de normas ou valores adotados historicamente por uma sociedade".

No contexto prático e, especificamente, nos estudos referentes ao comportamento organizacional, a ética tem sido constantemente abordada sob o 
enfoque da liderança, sobretudo no que tange a influência desta dimensão nos demais aspectos organizacionais correlatos. Os estudos de liderança recentes direcionam seus interesses aos líderes considerados autênticos e éticos. Estudos recentes indicam associação positiva entre líderes autênticos e o desempenho alcançado por seus subordinados (CAVAZOTTE, VILAS BOAS e MORENO, 2012; EBOLI, CAVAZOTTE e LUCENA; 2012).

A liderança baseada na autenticidade do líder é apresentada por Walumbwa e colaboradores (2008) a partir de quatro dimensões: (1) o autoconhecimento, ou percepção de si mesmo a partir de forças, fraquezas, valores e emoções; (2) a perspectiva moral internalizada, que se refere ao processo de auto-regulação individual no qual os comportamentos estão de acordo com a conduta moral, valores e crenças do líder, mesmo que sob pressões externas; (3) a transparência relacional, ou a maneira pela qual o líder estabelece suas relações, demonstrando sentimentos e pensamentos de forma verdadeira e emocionalmente apropriada; e (4) o processamento equilibrado de informações, que seria a habilidade de analisar e considerar opiniões e perspectivas diferentes da sua antes de tomar uma decisão.

A partir das quatro dimensões componentes da liderança autêntica, a perspectiva moral denota especial importância no desenvolvimento deste trabalho. Embora a perspetiva moral tenha sido estudada a partir da liderança autêntica, esta dimensão ainda carece de estudos mais robustos (GARDNER, COGLISER, DAVIS, DICKENS; 2011).

A conduta moral é uma zona de interseção considerada um fator crucial no desenvolvimento de uma liderança considerada autêntica (AVOLIO e GARDNER, 2005), assim como para uma liderança considerada ética (BROWN e TREVIÑO, 2006).

Uma das discussões acerca do pilar da moralidade internalizada é abordada no trabalho de Price (2003) sobre a possibilidade dos líderes autênticos agirem de maneira imoral nas situações em que por ventura possam estar "cegos" em relação aos seus próprios valores. Em contrapartida, Walumbwa et al (2008) argumenta que seria uma habilidade deste estilo de líder considerar diferentes perspectivas para a tomada de decisão. 
A capacidade do líder de reconhecer um dilema moral no local de trabalho está relacionada ao nível de intensidade de sua capacidade moral, que é um componente de sua personalidade. May, Hodges, Chan e Avolio (2003) desenvolvem uma abordagem positiva acerca do desenvolvimento dos líderes na qual acreditam que a maioria das pessoas tem um potencial inato para se tornar um líder moral autêntico. Segundo os autores, essa competência pode ser desenvolvida e aprendida a partir de experiências passadas, o que possibilita o reconhecimento e avaliação de dilemas morais no trabalho. Líderes autênticos têm uma alta capacidade moral para julgar dilemas sobre diferentes ângulos, sendo capazes de considerar as necessidades dos diferentes envolvidos, promover um clima de trabalho ético, agir com coerência aos seus valores, crenças e autoconsciência, de forma a integrar a conduta ética de sua vida pessoal com sua vida organizacional (MAY et. al., 2003).

Schulman (2002) aborda em seus estudos os recursos motivadores da moral do indivíduo concedendo especial atenção às diferenças individuais deste tipo de motivação. Segundo o autor, o reforço ou punição, recursos utilizados por algumas correntes teóricas de motivação, não são as mais eficazes quando se trata da atuação moral do indivíduo. Os fatores externos até podem representar a evitação de algum comportamento, mas o indivíduo conduzirá suas ações alinhadas a sua motivação moral interna.

A partir da teoria de desenvolvimento moral cognitivo (cognitive moral development - CMD) de Kohlberg (1964), foi proposta a organização do julgamento moral em estágios, compreendidos por três níveis: pré-convencional, convencional e pós-convencional; e dois estágios em cada nível, que se estendem da infância à vida adulta. O primeiro nível, pré-convencional, é característico de grande parte das crianças com menos de 9 anos, de alguns adolescentes e de criminosos; é uma fase em que não existe internalização de princípios morais. O ato é julgado pelas suas consequências e não pelas suas intenções, pois os indivíduos não chegam a entender e respeitar normas e expectativas compartilhadas (KOHLBERG; 1964 apud MONTEIRO, ESPIRITO SANTO e BONACINA; 2005). Neste estágio, o indivíduo apenas segue as ordens determinadas por uma figura que representa autoridade e o direciona para cumprir “ordens” (GRAHAM, 1995). 
No segundo nível, denominado convencional, as figuras de autoridade se afastam do indivíduo, cedendo espaço para a internalização do sistema de regras e responsabilidades, que passa a ser predominante (GRAHAM, 1995). A ação moral correta é baseada nas regras e normas estabelecidas formalmente, assim como pelas expectativas sobre as ações do indivíduo.

Já no terceiro nível, o chamado pós-convencional, se encontra o maior nível da competência moral, a ação é baseada em princípios morais éticos e não por regras universais, os valores como igualdade e reciprocidade são norteadores da ação (KOHLBERG; 1992 apud BATAGLIA, MORAIS e LEPRE; 2010). O indivíduo é capaz de considerar os diferentes tipos de interesses, equilibrando-os de forma respeitosa e cuidadosa (GRAHAM, 1995).

Kohlberg (1981) apud Lee, Stettler e Antonakis (2011) apontam que há uma variação no grau de princípios éticos dos indivíduos no que concerne aos relacionamentos sociais e visão de justiça. No trabalho, aqueles que possuem maior nível de desenvolvimento ético são propensos a apresentar obediência e auto-disciplina, o que pode ser traduzido por uma forte ética contribuindo para o desempenho acadêmico e do trabalho.

A partir do desenvolvimento das teorias que investigam a autenticidade e moralidade, como valores norteadores de líderes e consequentes comportamentos e atitudes dos indíviduos, este estudo tem como alvo as figuras envolvidas no processo de liderança de uma organização: o líder, gerente da referida organização, e sua equipe de funcionários. Para contextualizar a abordagem da ética na teoria de liderança, o item da próxima seção é liderança ética.

\subsection{2.}

\section{Liderança ética}

As recentes crises morais do último século nos âmbitos social, empresarial e político têm despertado crescente interesse pelo estudo da liderança no que diz respeito à perspectiva ética (CIULLA, 2004; GEORGE, 2007; MAY, HODGES, CHAN e AVOLIO, 2003; BROWN e TREVIÑO, 2006). Uma iniciativa que demonstra a preocupação do engajamento de líderes mundiais com a ética na sustentabilidade, por exemplo, é o Pacto Global, um projeto desenvolvido pela ONU (Organização das Nações Unidas) e lançado oficialmente no ano 2000. A 
governança do Pacto Global é composta pos seis entidades, dentre elas a cúpula de líderes do Pacto Global, integrada por executivos de empresas participantes. O objetivo principal é discutir assuntos como preservação do meio ambiente, responsabilidade social e governança corporativa para que a nova era de sustentabilidade esteja de fato integrada na gestão das empresas sabendo que, para isso, o papel da liderança é mandatório (METCALF e BENN, 2012).

A partir dessa perspectiva, o estudo da abordagem teórica sobre a liderança ética nos ajuda a compreender de que maneira os líderes afetam o comportamento ético nas empresas, assim como consequentes atitudes dos funcionários envolvidos por este estilo de liderança. Estudos envolvendo a liderança ética demonstram relação positiva entre este estilo de liderar e a satisfação com seu líder, avaliação da efetividade do mesmo e a dedicação dos seguidores no desempenho de um esforço extra relacionado ao desempenho (BROWN et al., 2005).

A liderança ética foi definida por Brown, Treviño e Harrison (2005) como: "a demonstração de conduta apropriada através de ações pessoais, relações interpessoais bem como a promoção de tal conduta para os seguidores através de uma comunicação bidirecional, reforço e tomada de decisão". Esta teoria é ancorada na teoria da aprendizagem social de Bandura (1986), que tem como premissa básica a aprendizagem a partir da experiência prática ou indireta, através da obervação do comportamento de terceiros.

Uma vez que a definição da liderança ética apresenta semelhanças quando comparada com a teoria da liderança autêntica, é necessário esclarecer as diferenças entre elas. Especificamente, o que é comum às duas se concentra no caráter ético e moral como valor norteador para a conduta e comportamentos do líder. No entanto, este é apenas um componente da liderança considerada autêntica, que, como citado anteriormente, é ainda composta pelas dimensões do autoconhecimento, transparência relacional e processamento equilibrado de informações. Portanto, o comportamento ético do líder é condição necessária para se caracterizar a liderança autêntica, no entanto, isoladamente, não é suficiente (WALUMBWA et al., 2008). 
Sob o ponto de vista de Schulman (2002), a caracterização ética de um indivíduo contempla um comportamento norteado por ações corretas baseadas na equidade e que beneficiam uma ou mais pessoas, e não por atos assumidos isoladamente ou sob condições especiais, como coerção, obrigação ou reciprocidade. A teoria do autor sobre a motivação moral aponta para a existência de três recursos: a empatia, afiliações morais (ou identificações com modelos morais) e princípios ou padrões de certo ou errado.

Segundo o mesmo autor, a empatia se caracteriza pela capacidade humana de experienciar o que outras pessoas estão sentindo e, portanto, uma das maneiras de um indivíduo se tornar moral seria pela capacidade de considerar o sentimento de outras pessoas, em especial o sofrimento. A afiliação moral ocorre a partir da identificação com "bons" modelos morais, que podem ser representados por qualquer figura que exerça tal influência, como os pais. O estabelecimento de princípios e padrões morais é quando o indivíduo segue determinadas regras de conduta, independente da aprovação ou reprovação de qualquer figura que represente autoridade e até mesmo quando não há empatia com pessoas com as quais há interação.

Claramente é reservada ao líder ético grande influência no que concerne ao comportamento de seus seguidores. Devido ao estabelecimento de padrões baseados na ética a partir da honestidade ecuidado com terceiros, esses líderes despertariam sentimentos de confiança e gratidão que por sua vez responderiam com atitudes e comportamentos positivos. O bom relacionamento entre líderes e liderados, em parte, pode ser atribuido aos valores compartilhados e identificação dos seguidores com seus líderes (BROWN e TREVIÑO, 2006).

Estudos recentes corroboram esta ideia, uma vez que têm demonstrado o efeito positivo entre a liderança ética e o comportamento dos seguidores (PICCOLO, GREENBAUM, DEN HARTOG e FOLGER, 2010; WALUMBWA, MAYER, WANG, WANG, WORKMAN e CHRISTENSEN, 2009). Estes líderes praticam o que de fato pregam e, devido a esta característica, funcionam como uma espécie de modelo de conduta ética (BROWN e TREVIÑO, 2006); eles consideram as consequências éticas de suas decisões fazendo opções justas que poderão ser observadas e compartilhadas por terceiros (BROWN et al, 2005). No que se refere a sua equipe, seus comportamentos e ações funcionam como um 
exemplo para seus seguidores. É nesta perspectiva que a teoria da liderança ética resgata e utiliza o conceito da teoria de aprendizagem social de Bandura (1986).

Um líder guiado por valores éticos como o altruísmo e justiça apresenta maior motivação para dar suporte, desenvolver e auxiliar seus subordinados. Assim, líderes éticos oferecem justas oportunidades de desenvolvimento de carreira, reconhecem o trabalho de seus subordinados através de recompensas e se comportam de forma transparente e assertiva, não tratando seus funcionários de forma abusiva e exploradora (MASHUD, YUKL e PRUSSIA, 2010).

Ainda que a liderança não seja o único determinante para a capacidade de raciocínio moral dos seguidores, a inspiração e o incentivo que desempenham podem influenciar de diferentes maneiras o desenvolvimento moral dos mesmos (GRAHAM, 1995). Duas dimensões da personalidade devem contemplar um líder para que seja considerado ético: gestor moral e pessoa moral. O gestor moral se refere à maneira na qual o líder utiliza ferramentas de sua posição para influenciar comportamentos éticos em seus seguidores no ambiente de trabalho. A pessoa moral se refere à maneira honesta, confiante, cuidadosa e respeitosa com que o líder se relaciona com seus funcionários, fornecendo o suporte necessário (BROWN et al, 2005; TREVIÑO, BROWN e HARTMAN, 2003). A afirmação a seguir corrobora a ideia dos autores: "Quando eu trabalho, meu comportamento é ético se evito resultados vantajosos para mim e prejudiciais para os outros" (DE MASI, 2000; p. 336).

Um estudo conduzido por De Hoogh e Den Hartog (2008) demonstrou significativa relação entre líderes socialmente responsáveis, moralidade, justiça e comportamento de compartilhamento de poder, aspectos relacionados à liderança ética. Dessa maneira, embora a teoria ainda não explique claramente como o comportamento do líder está relacionado com a relação de troca com um subordinado, há a indicação de que valores éticos são antecedentes de melhor relacionamento entre líder-seguidor ou LMX, leader-member exchange (MAHSUD et al., 2010), conceito apresentado a seguir. 


\section{2. \\ LMX (Leader Member Exchange)}

A teoria Leader-member Exchange (LMX), inicialmented esenvolvida na década de 70, trouxe uma abordagem inovadora à época, quando comparada às teorias de liderança já existentes. O cerne de sua concepção está na abordagem da liderança como um processo, fruto da interação entre líderes e seguidores, de forma que a relação diática passou a ser o principal alvo de investigação dos pesquisadores. A partir desse novo prisma, a liderança deixa de ser analisada apenas como um processo coletivo no qual o líder utiliza um estilo de liderar para um grupo de pessoas. O que mereceria atenção é a relação que o líder estabelece com cada seguidor individualmente (NORTHOUSE, 2010).

Essa definição explicita que, devido ao relacionamento estabelecido desde o início entre líder-liderados, há a implicação de consequências que contam com a formação de dois grupos distintos: o in group, ou endogrupo, mais integrado ao líder, com relações informais, baseadas em alta confiança e recompensas, e o out group, ou exogrupo,cujo relacionamento é baseado na formalidade, com regras, baixa confiança, interação e suporte limitados (DIENESCH e LIDEN, 1986).

Dessa maneira, enquanto a relação LMX dos indivíduos que estariam no "out group" se caracterizariam por ser de baixa qualidade, restrita ao contrato formal, a relação LMX estabelecida com pessoas do "in group" seria de alta qualidade, caracterizada por um relacionamento de mútuas trocas de recursos e suporte que vão além do que é exigido no contrato formal de trabalho (LE BLANC e ROMÁ, 2012) .

A origem de grande parte dos estudos relacionados à teoria LMX parece estar atribuída ao ponto crucial desta corrente teórica: os efeitos resultantes do relacionamento do líder com cada seguidor indivualmente. A condução de alguns estudos realizados nessa linha revela que a alta qualidade da relação de troca entre líder e seguidor desencadeia menor turnover de funcionários, melhores atitudes no trabalho, maior comprometimento organizacional, além da maior frequência de promoções, melhor participação e desempenho, mais atenção e suporte do líder (GRAEN e UHL-BIEN, 1995; LIDEN, WAYNE e STILWELL, 1993; COGLISER, SCHRIESHEIM, SCANDURA e GARDNER, 2009). 
A partir dos resultados positivos relacionados à alta qualidade LMX, uma pergunta pertinente é: como exatamente é a influência da relação líder-seguidor? Pesquisas de liderança realizadas pela comunidade acadêmica visam responder este questionamento. Estudos recentes envolvendo pesquisas empíricas demonstram influência positiva da liderença ética em LMX (TUMASJAN, STROBEL e WELPE, 2010; MASHUD et al., 2010).

\subsection{1.}

\section{Liderança ética e LMX}

Brown, Treviño e Harrison (2005) acreditam que à medida que líderes são percebidos pelos seguidores por apresentarem uma motivação menos egoísta e mais altruísta (comportamento honesto, consideração por outros e tratamento justo), eles criam um ambiente de trabalho agradável e justo. Assim, passam a ser líderes legitimados, com uma conduta admirável, fonte de identifação e inspiração. Líderes possuidores desses valores têm maior desejo de desenvolver e manter uma relação de colaboração com sua equipe (YUKL, 2010).

Uma vez que o seguidor é um componente fundamental no processo de liderança, é pertinente verificar a influência da conduta ética do líder sobre ele. A teoria de Bandura (1986) salienta o aprendizado por meio da experiência direta ou indireta através da observação de comportamentos de terceiros e suas consequências. Brown et al. (2005) abordam a importância deste conceito quando aplicável a conduta ética nas organizações. Os autores defendem que os funcionários de uma organização podem aprender o que é esperado deles a partir dos comportamentos, recompensas e punições praticadas por seus líderes. Estes funcionariam como fonte de exemplo, talvez a mais importante, em virtude do papel atribuído pelo status e sucesso na organização, assim como o poder de influência sobre o comportamento e resultados de terceiros.

De acordo com Davel e Machado (2001), o processo de liderar envolve a capacidade de dar significado àquilo que as pessoas estão fazendo, trata-se de um relacionamento mútuo entre líder e seguidor e que, portanto, envolve influência em duplo sentido. Segundo os autores, o processo de identificação social é constituído (1) pela filiação a uma categoria social, (2) pelo prestígio dos valores e práticas do grupo em comparação a outros (OAKES e TURNER, 1986) e (3) 
pelos fatores que são associados à formação psicossocial do grupo. $\mathrm{O}$ conjunto de fatores como interações interpessoais, similaridade, proximidade, objetivos partilhados e história em comum podem afetar a abrangência da identificação dos indivíduos com o grupo (ASHFORTH e MAEL, 1989).

As relações sociais estabelecidas no ambiente de trabalho têm sido alvo de investigação empírica a fim de identificar e compreender o seu impacto no engajamento com o trabalho, satisfação, comprometimento, desempenho individual, e, consequentemente, no resultado organizacional. Como abordam Brown et al. (2005), a perspectiva da aprendizagem social propõe que a conduta ética dos líderes influencia a conduta ética dos seguidores pela observação, imitação e identificação.

O efeito dos valores éticos de um líder são observados em situações diárias, a partir da definição de sólidos padrões de conduta ética. A distribuição de recompensas e benefícios de maneira justa, a mediação de conflitos com imparcialidade e a dedicação com que líderes éticos tratam suas equipes são responsáveis por estabelecer um melhor relacionamento e gestão (MAHSUD et al., 2010).

Assim é elucidada a primeira hipótese deste estudo:

H1a: A liderança ética, avaliada pela ótica dos seguidores, afeta positivamente a qualidade da relação de troca entre líder e liderados (LMX - leader member Exchange)

\section{3.}

\section{Díade Líder-seguidor e LMX}

Consensualmente, aliderança é definida como um processo que envolve líder e seguidor em um determinado contexto (NORTHOUSE, 2010), assim, para que um líder seja considerado ético, é condição que seus seguidores o legitimem como tal. Esse relacionamento é envolvido pela personalidade e características peculiares do líder e também daqueles que o seguem. Dessa maneira, um construto importante na construção do modelo da presente pesquisa é o Self Other Rating Agreement (SOA), que será apresentado a seguir. 


\subsection{1. \\ SOA - Self Other Agreement}

Self Other Rating Agreement (SOA) pode ser traduzido para o português como Congruência entre Autoavaliações e Avaliações de Terceiros. Em liderança, diz respeito ao grau de concordância ou congruência entre a autoavaliação de um líder e as avaliações dos demais colegas de trabalho, como superiores, pares e subordinados (ATWATER, WANG, SMITHER e FLEENOR, 2009; FLEENOR, MCCAULEY e BRUTUS, 1996; OSTROFF, ATWATER, e FEINBERG, 2004; YAMMARINO e ATWATER, 1993). Esta definição, portanto, diz respeito à análise do alinhamento de uma variável a partir de duas visões diferentes.

A primeira constatação interessante a respeito do alinhamento da avaliação do gestor e sua equipe é o nível de autoconhecimento que a autoavaliação pode possibilitar. Sobretudo, o líder que apresenta autoavaliação convergente com a classificação do grupo com o qual trabalha pode apresentar maior nível de conhecimento sobre si mesmo quando comparado ao que apresenta divergência entre a autoavaliação e as avaliações dos demais (FLEENOR, SMITHER, ATWATER, BRADDY e STURM; 2010).

De forma a contribuir com a administração e a eficácia das organizações, a intrigante questão que a literatura visa responder é se há relevância no alinhamento das autoavaliações dos líderes com as avaliações de terceiros (pares ou subordinados) para o resultado individual e organizacional (ATWATER, OSTROFF, YAMMARINO e FLEENOR; 1998).

Em um dos modelos mais relevantes encontrados na literatura a respeito do SOA - Self Other Rating Agreemente em relação aos resultados, Atwater e Yammarino (1997) desenvolvem quatro categorias: (1) superestimação; ocorre quando a autoavaliação do líder é em geral maior do que as avaliações de terceiros; (2) subestimação; a autoavaliação do líder é representativamente menor que as avaliações de terceiros; (3) alinhamento-alta classificação; é quando a autoavaliação do líder é alta e, da mesma forma, é reconhecida pelo grupo; (4) alinhamento-baixa classificação; é quando a autoavaliação do líder é baixa e, da mesma maneira, é reconhecida pelo grupo. 
Há indicações que permitem concluir que a eficácia do desempenho do líder apresenta maior nível quando ambas as avaliações (autoavaliação e a avaliação de terceiros) são altas e quando há uma subestimação da autoavaliação, ou seja, avaliação do gestor é substancialmente mais baixa do que a avaliação de seus subordinados. Por outro lado, a eficácia apresenta um nível menor quando há uma tendência a superestimação: as autoavaliações são moderadas e as avaliações dos subordinados são baixas (ATWATER et al, 1998). Ainda há os casos em que os líderes concordam com as avaliações de terceiros quanto ao baixo nível de eficácia. Neste caso, há maior propensão a estarem vinculados a resultados negativos. Especificamente, estes perfis de líderes seriam mais relutantes ou incapazes de realizarem mudanças (ATWATERe YAMMARINO; 1997). Em contrapartida, a subestimação da autoavaliação do líder pode representar um interesse constante de melhoria e a tendência a não se tornar confiante em excesso. A seguir, a síntese do modelo proposto:

\begin{tabular}{|c|c|c|c|}
\hline Fenômeno observado & $\begin{array}{c}\text { Autoavaliação } \\
\text { líder }\end{array}$ & $\begin{array}{c}\text { Avaliação } \\
\text { subordinados }\end{array}$ & $\begin{array}{c}\text { Performance/ } \\
\text { Eficácia }\end{array}$ \\
\hline $\begin{array}{c}\text { Alinhamento Alta } \\
\text { classificação }\end{array}$ & Alta & Alta & Muito positiva \\
\hline Superestimação & Alta & Baixa & Muito negativa \\
\hline Subestimação & Baixa & Alta & Mista \\
\hline $\begin{array}{c}\text { Alinhamento baixa } \\
\text { classificação }\end{array}$ & Baixa & Baixa & Negativa \\
\hline
\end{tabular}

Tabela 1: Síntese do modelo - Yammarino \& Atwater (1997)

Com o objetivo de reproduzir este modelo, estudos têm demonstrado relevância ao considerarem a autoavaliação e avaliação de terceiros na eficácia ou desempenho dos gestores (ATWATER et al, 1998; BRUTUS, FLEENOR e TISAK, 1999; ATWATER, WALDMAN, ROBIE, OSTROFF e JOHNOSON, 2005;FLEENOR, MCCAULEY e BRUTUS, 1996). Os resultados dessas pesquisas indicam que os gestores que subestimam suas autoavaliações e que apresentam convergência em relação às altas médias das avaliações de terceiros apontam para maior desempenho ou nível de eficácia.

No contexto organizacional, a indicação deste modelo pode ser valiosa no que tange aos programas de desenvolvimento de liderança e os consequentes desdobramentos para as esquipes de trabalho. Com base nas informações de 
feedback de sua equipe, gestores têm maior contribuição para a estratégia de desenvolvimento de habilidades (ATWATERe YAMMARINO, 1997).

A discussão acerca do construto é ampliada ao verificarem fatores que possivelmente podem influenciar nas autopercepção e autoavaliações: características demográficas, processos cognitivos, experiências de trabalho relevantes, características individuais de pesonalidade e contexto (ATWATER e YAMMARINO, 1997). Embora alguns trabalhos na área relacionem este conceito à personalidade e características pessoais, como a empatia ou "Big Five" (os cinco fatores da personalidade), não foi encontrado na literatura sobre o tema nenhum estudo envolvendo a ética (FLEENOR et al, 2010).

\subsection{2.}

\section{Self-Other Agreement (SOA) e LMX}

Na presente pesquisa é realizada a autoavaliação do líder em relação a sua ética no trabalho, assim como a avaliação da liderança ética sob a ótica dos funcionários. Com isso, apresenta-se o objetivo de verificar o nível de congruência entre tais avaliações e o impacto na qualidade do relacionamento entre líder-liderado. Essa análise denotará o quão similar é a visão de um líder e da equipe liderada por ele.

A hipótese é que a congruência do julgamento positivo da liderança ética seja um antecedente da alta qualidade de LMX. Ou seja, uma vez que o gestor se auto-avalie como um líder ético e a avaliação da ética do líder pelo seu seguidor seja correspondente, espera-se que exista maior qualidade da relação de troca entre eles (LMX). Dessa maneira, no modelo, a liderança ética será um construto medido pelo líder e seus liderados.

Assim, define-se a primeira hipótese:

H1b: A congruência da liderança ética, avaliada pelo líder e seus seguidores (SOA), afeta positivamente a qualidade da relação de troca entre ambos (LMX-leader member exchange) 


\subsection{3. \\ Fit - Congruência Líder e seguidor}

Um dos aspectos investigados na pesquisa relacionada à congruência da pessoa com o ambiente de trabalho concentra esforços na investigação da congruência de valores entre indivíduos e colegas de trabalho (Person-Person, PP). O assunto ganha notoriedade quando há possibilidade de verificação da relação do gestor e funcionários e possíveis consequências referentes ao comportamento dos liderados, como: satisfação com o trabalho, comprometimento organizacional e desempenho individual (KRISTOF-BROWN et al., 2005; ZHANG et al., 2012; OSTROFF, SHIN e KINICKI, 2005; EDWARDS e CABLE, 2009). Em um estudo conduzido por Zhang, Wang e Shi (2012), a congruência da personalidade pró-ativa de líderes e seus liderados fundamenta e contribui para a relação LMX de alta qualidade, o que por sua vez funciona como mediadora nos níveis de satisfação com o trabalho, desempenho individual e comprometimento afetivo estabelecido com a organização.

Além de investigarem o âmbito relacional, também são consideradas variáveis demográficas como sexo, idade e educação (TSUI e O'REILLY, 1989). A congruência relacionada ao ambiente ou em inglês, fit (Person Enviroment $P E)$, é definida como a compatibilidade, o encaixe entre o indivíduo e o ambiente de trabalho quando as características são bem combinadas. Nesta definição, estão relacionados o alinhamento do indivíduo com seu trabalho, a organização, o grupo de trabalho e o gestor. O termo tem sido abordado alternativamente como similaridade e sua utilização aparece em estudos com diferentes variáveis, como: habilidades, necessidades, preferências, valores, traços de personalidade, metas e atitudes (KRISTOF-BROWN et al., 2005). A partir do fit há a possibilidade de analisar a diferença ou aproximação de uma mesma variável através de perspectivas diferentes.

Embora estudos nesta temática tenham investigado a relação de congruência dos valoresentre gestor e subordinados, o que pode significar maior ou menor qualidade da relação, poucos analisaram a relação estabelecida com a LMX, apesar dessa variável ter apresentadorelevância nas análises (MARKHAM, YAMMARINO, MURRY e PALANSKI, 2010). 
Desde a década de 80, a percepção de similaridade entre valores do gestor e subordinado têm demonstrado relevância no desenvolvimento da relação de troca entre ambos (STEINER, 1988). Como apontado por Kemelgor (1982), a semelhança dos valores do líder e subordinado é um importante fator no desenvolvimento das relações de LMX tendo impacto positivo com a satisfação no trabalho. Em estudo mais recente, a variável LMX se apresenta como moderadora da congruência dos valores do trabalho de gestor e subordinado e a satisfação com a carreira (ERDOGAN, KRAIMER e LIDEN, 2004).

A autoidentidade diz respeito à investigação sobre a maneira pela qual os indivíduos se auto definem considerando impactos de ordens sociais (JACKSON e JONHSON, 2012). Trata-se de uma espécie de conhecimento que cada indivíduo tem sobre si mesmo (VAN KNIPPENBERG et al., 2004). O nível relacional envolve as autodefinições baseadas nos relacionamentos díades entre pessoas específicas como colegas de trabalho ou o gestor. Um estudo conduzido por Jackson e Johnson (2012) investigou os efeitos da semelhança da autoidentidade de líder e seguidores na qualidade do relacionamento entre eles (LMX). Os resultados apontam que a qualidade da relação entre gestor e funcionário apresenta uma tendência a ser maior quando os gestores têm fortes identidades relacionais ou quando gestores e subordinados apresentam níveis de identidades relacionais semelhantes.

A tabela a seguir explicita as definições de SOA e FIT:

\begin{tabular}{|c|c|c|c|}
\cline { 2 - 4 } \multicolumn{1}{c|}{} & Variável & Líder & Seguidor \\
\hline FIT & Ética própria & Autoavaliação & Autoavaliação \\
\hline SOA & Ética do líder & Autoavaliação & $\begin{array}{c}\text { Avaliação da ética } \\
\text { do líder }\end{array}$ \\
\hline
\end{tabular}

Tabela 2: FIT e SOA 


\subsection{4.}

\section{Congruência ética Líder-Seguidor (FIT) e LMX}

As características dos líderes são fatores importantes na influência de atitudes relativas ao trabalho e desempenho dos seguidores. Uma vez que os funcionários tenham uma alta qualidade na relação de troca com seu líder (LMX), haveria por parte do liderado uma valorização da relação pessoal de forma a responder positivamente às expectativas relacionadas ao trabalho (KAMDAR e VAN DYNE; 2007).

Em um estudo conduzido por Zhang et al. (2012) é possível observar que a semelhança no nível de proatividade de líderes e seus subordinados produz um efeito importante na qualidade do relacionamento entre eles (LMX). Como consequência deste fato, há um efeito positivo na satisfação com o trabalho, comprometimento organizacional afetivo e desempenho individual.

Inspirado neste modelo, este estudo pretende investigar se a congruência da ética de seguidores e seus líderes é um fator preditor de uma relação de melhor qualidade entre eles. Assim, a partir de um mesmo instrumento de medida será realizada a avaliação da ética de um grupo de gestores e seus respectivos funcionários, o que permitirá analisar o grau de alinhamento ético a partir dessas duas categorias e, portanto, verificar a hipótese:

H1c: O alinhamento da ética de líderes e seguidores (FIT) afeta positivamente a qualidade da relação de troca entre ambos (LMX leader member exchange).

\section{4.}

\section{Desempenho Individual}

Na literatura é possível verificar a existência de diferentes definições para desempenho. Performance, eficiência, efetividade e produtividade são nomenclaturas que aparecem como objeto de estudo em diversas áreas do conhecimento sendo discutidas, portanto, em diversos níveis de análises. O interesse da academia pelo tema pode ser corroborado pelo fato de ser o constructo mais pesquisado na literatura referente ao gerenciamento de recursos humanos e comportamento organizacional (BANDURA e JOURDEN, 1991). 
$\mathrm{Na}$ dimensão individual, o termo desempenho é usado para definir a proficiência com a qual os funcionários agem e se comportam de forma relevante para a organização. Assim, o desempenho alcançado é o conjunto dos resultados originados pelos comportamentos e atitudes dos indivíduos no trabalho. A efetividade do desempenho é geralmente avaliada percentualmente, de forma a comparar o que foi atingido com o que se era esperado (MOTOWIDLO, BORMAN e SCHIMIT; 1997).

O engajamento, o comprometimento e a satisfação do funcionário com o trabalho que realiza podem aumentar o desempenho individual e, portanto, serem aliados importantes dos resultados organizacionais. Paterson et al. (1997) afirmam que práticas de trabalho em equipe, participação, avaliação de performance e incentivos podem influenciar positivamente o comprometimento do funcionário, sua satisfação e sua motivação, o que vai aumentar a performance, a cidadania e reduzir o absenteísmo e o turnover.

Um viés importante no estudo da avaliação de desempenho individual é que líderes podem atribuir ao processo de avaliação de desempenho um conjunto de características diferenciadas para quem é semelhante ou diferente deles. Dessa forma, as avaliações seriam realizadas com base em categorizações mais do que em observações reais (BAUER e GREEN, 1996). De maneira a minimizar este tipo de impacto, nesta investigação a métrica de desempenho utilizada será também objetiva. Será considerado o percentual de atingimento da meta em vendas em um trimestre.

O modelo de desempenho proposto por Motowidlo et al. (1997) aborda a influência das características individuais referentes à personalidade e habilidade cognitiva no desempenho. Este, por sua vez poderia ser definido de duas maneiras: (1) o desempenho da tarefa, que se relaciona diretamente a atividades técnicas e (2) o desempenho contextual, que estaria relacionado a uma perspectiva mais ampla, envolvendo o aspecto social.

O desempenho contextual teria surgido a partir da preocupação com a negligência do caráter social e psicológico que também envolvem o desempenho do indivíduo em uma organização (LEPINE, EREZ e JOHNSON, 2002). Assim, este tipo de desempenho estaria relacionado às atividades que abrangem o 
comportamento de ajuda, suporte, respeito pelas regras organizacionais e esforço extra em atividades que não estariam formalmente relacionadas ao trabalho desenvolvido. Este tipo de desempenho se relaciona às denomidas características adaptativas, que envolvem preferências, atitudes, hábitos e componentes do comportamento que podem ser aprendidos através das relações estabelecidas com o ambiente. Assim, este processo contempla variáveis como habilidades sociais, atitudes religiosas, regras sociais, valores morais $\mathrm{e}$ atitudes políticas (MOTOWIDLO et al, 1997).

O envolvimento do líder nesse processo é primordial, uma vez que ele é a chave para o alinhamento dos sistemas organizacionais e comportamentos dos funcionários em torno de uma visão organizacional. É através dele que é realizada a ponte entre organização, suas aspirações e os funcionários que são responsáveis por transformar a estratégia e o plano em realidade (PETERSON E HICKS,1995). É compreensível, portanto, a crescente importância atribuída à habilidade de liderar e à gestão de pessoas nas organizações no que concerne ao desenvolvimento de ferramentas que aperfeiçoem a gestão e, consequentemente, desempenho dos funcionários.

\subsection{1. \\ LMX (Leader Member Exchange) e Desempenho}

Os resultados de uma organização podem ser favorecidos pelo líder através de sua influência sobre os determinantes de desempenho da mesma. Uma perspectiva importante contempla o comportamento do líder e suas interações com os subordinados, incluindo suporte, reconhecimento, desenvolvimento através de ferramentas de coaching e mentoring, delegação e contribuição para um clima de colaboração entre a equipe (YUKL, 2008). Como salienta Zhang, Wang e Shi (2012), líderes são responsáveis pelo controle das atividades de seus funcionários, têm um papel importante no que concerne ao engajamento, iniciativa e desempenho.

Com base na teoria de LMX, que envolve a relação de troca entre líder e seguidor, estudos têm investigado o impacto deste relacionamento nos resultados, atitudes e comportamentos dos funcionários. No que se refere ao desempenho, 
essa relação tem sido positiva (BAUER, ERDOGAN, LIDEN e WAYNE, 2006; KLEIN e KIM, 1998; DUNEGAN, DUCHON e UHL-BIEN, 1992).

Uma explicação possível para que um gestor possa afetar diretamente o desempenho de um funcionário é que, ao ajudar na remoção de obstáculos referentes ao trabalho, fornecer o suporte necessário, encorajamento e coaching, a qualidade da relação seja melhor. Portanto, esse funcionário pode apresentar desempenho superior a um funcionário que não possui o mesmo investimento de tempo (VECCHIO e GOBDEL, 1984).

Embora a relação entre LMX e desempenho tenha sido observada em estudos importantes para o desenvolvimento dessa teoria de liderança, é preciso atenção ao analisá-la e estabelecer suas métricas. Heneman, Greenberger e Anonyo (1989) criticaram as métricas subjetivas utilizadas em alguns estudos (DANSEREAU, GRAEN e HAGA, 1975; DUARTE, GOODSON e KLICH, 1994), argumentando que teriam pouca ou nenhuma relação com o desempenho individual real.

Klein e Kim (1998) abordam a existência de estudos com métricas de desempenho objetivas que apresentaram pouca ou nenhuma relação positiva com LMX em seus resultados (LAGRACE, 1990; VECCHIO e GOBDEL, 1984). Uma explicação possível atribuída pelos autores a estes resultados discrepantes é o fato da avaliação de desempenho ter sido definida de forma restrita não levando em consideração algumas variáveis que pareciam denotar importância. Em uma destas pesquisas, o atendimento ao cliente e comportamento de cidadania pareciam extremamente adequados ao contexto do estudo, no entanto, não foram considerados.

De forma a minimizar este efeito no estudo conduzido por Klein e Kim (1998) é incluida uma métrica que avaliou o comprometimento com a meta. O alto desempenho dos funcionários é esperado quando, além da boa qualidade da relação do líder e subordinado (LMX), o funcionário tem comprometimento com metas desafiadoras. Uma vez que o comprometimento com a meta e a relação de LMX sejam baixos, o desempenho deverá também ser baixo; e, no caso do comprometimento com a meta ser baixo e a relação de LMX ser alta, o desempenho terá a tendência a ser inferior. Neste caso, imagina-se que a dimensão 
de desempenho consideradaseja mais inclinada à subjetividade. Segundo esta proposição, a boa relação entre lídere subordinado demonstra sua relevância quando embora o funcionário tenha alto comprometimento com metas desafiadoras, se ele tiver baixa qualidade de LMX, seu desempenho deverá ser baixo uma vez que não terá os recursos, o suporte e atenção necessária de seu gestor para a execução da tarefa.

Esse argumento parece ter relação com o que é apontado por Zhou e Schriesheim (2009) quando propõem que líderes e seus funcionários encaram LMX de maneiras distintas. Enquanto os líderes estariam mais propensos ao julgamento das relações LMX a partir de tarefas relacionadas ao trabalho, seus funcionários estariam mais propensos a utilizarem fatores sociais para julgamento de suas relações LMX com seus líderes.

Dessa forma, reporta-se a segunda hipótese:

H2: A qualidade da relação dos líderes e seguidores (LMX - Leader Member Exchange) afeta positivamente o desempenho individual

\section{5 . \\ Comportamento de cidadania organizacional (CCO)}

Entende-se por comportamento de cidadania organizacional o comportamento individual voluntário, não diretamente ou explicitamente reconhecido pelo sistema de recompensa formal e que, de alguma forma, promove o bom funcionamento organizacional. Entende-se por voluntário aquele comportamento não esperado pelo contratoformal estabelecido com a organização, é uma escolha pessoal que, mesmo que não esteja presente, não há punição (ORGAN, 1988; apud PODSAKOFF, MACKENZIE, PAINE e BACHRACH, 2000).

Talvez um dos principais motivos que fazem deste assunto um importante campo de estudo na área de comportamento organizacional seja seu impacto na eficácia das organizações. $\mathrm{O}$ aumento da eficiência organizacional através da melhoria na produtividade dos indivíduos de uma equipe é uma consequência do comportamento de cidadania (PODSAKOFF e MACKENZIE, 1997). Os referidos autores afirmam que a melhoria no desempenho ocorre, por exemplo, quando funcionários recém contratados têm auxílio de funcionários mais experientes, 
fazendo com que os mesmos sejam produtivos mais rapidamente. Outro comportamento que teria impacto na produtividade é o compartilhamento das melhores práticas entre os indivíduos de uma equipe ou grupo.

Segundo Organ e Ryan (1995), a definição de comportamento de cidadania organizacional encontra semelhança com a abordagem sobre o desempenho contextual, ítem abordado anteriormente (MOTOWIDLO et al., 1994). A contribuição do indivíduo para a efetividade da organização vai além de suas funções relacionadas à tarefa e que, informalmente, denota relevância devido ao contexto social da organização e o suporte fornecido ao trabalho propriamente dito. Voluntariar-se para a execução de atividades não relacionadas ao seu trabalho, ajudar terceiros, esforçar-se para realizar uma atividade extra, seguir as regras e procedimentos informais são exemplos de desempenho contextual e comportamentos de cidadania organizacional. E onde esses dois construtos se diferenciam? A diferença básica consiste na ênfase para as atitudes e fatores da personalidade que norteiam os comportamentos observados na cidadania organizacional (ORGAN e RYAN, 1995).

Alguns estudos indicam que o clima de trabalho é positivamente impactado pelo comportamento de cidadania, ainda que indiretamente. Envolvidos pelo comportamento de ajuda mútua, os funcionários experimentam um sentimento de coesão e pertencimento a uma equipe, fazendo da referida organização um lugar mais atrativo para se trabalhar. Assim, é possível inferir que há reflexos no processo de atração e retenção de pessoas.

A partir dos primeiros estudos na década de 80, que utilizaram a denominação "comportamento de cidadania organizacional", é crescente o número de pesquisas sobre as diferentes dimensões que fazem referência a este construto. A partir do levantamento realizado por PODSAKOFF e seus colaboradores (2000), quase trinta formas de cidadania podem ser identificadas, no entanto, tal diversidade poderia ser analisada a partir de sete grandes dimensões, classificadas como: (1) comportamento de ajuda, (2) esportividade, (3) lealdade organizacional, (4)obediência organizacional ou conscienciosidade, (5)iniciativa individual, (6) virtude cívica e (7)autodesenvolvimento. 
Inúmeros estudiosos, entusiasmados pela contribuição do CCO à eficácia das organizações, concentram seus estudos nos antecedentes deste construto (REGO, 2002). Assim, é profusa a lista de antecedentes a este tipo de comportamento; além de avaliarem as atitudes e características de personalidade (BARNES e LEA, 2004), investigam comportamentos de liderança e características organizacionais e do trabalho. É posssível encontrar a satisfação do trabalho e o comprometimento organizacional como variáveis recorrentes desses estudos (KONOVSKY e ORGAN, 1996; WILLIAMSe ANDERSON, 1991).

Comportamentos de cidadania organizacional foram descritos por Smith, Organ e Near (1983) como tendo duas dimensões básicas: o altruísmo e obediência organizacional ou conscienciosidade. A primeira, refere-se ao comportamento de ajuda direcionado especificamente aos colegas de trabalho quando estes têm algum tipo de problema ou precisam de alguma assitência. O outro tipo de comportamento é mais impessoal, diz respeito à postura adotada pelo profissional ao direcionar suas atitudes de forma correta e adequada, contemplando seu próprio bem.

De maneira análoga, foram identificadas por Williams e Anderson (1991) duas dimensões acerca da cidadania organizacional: $O C B-O$, comportamentos de cidadania que beneficiam a organização diretamente e $O C B-I$, comportamentos de cidadania que beneficiam indivíduos de forma direta e que, indiretamente, contribuem com a organização. Um exemplo de comportamento que beneficia diretamente a organização é a aderência a regras informais que mantêm a ordem organizacional. Um exemplo de comportamento referente à cidadania individual é a ajuda a um colega que tenha se ausentado do trabalho por algum período de tempo.

Nesta pesquisa, trabalharemos com o conceito de comportamento de cidadania organizacional estruturado por Williams e Anderson (1991). Uma vez que se acredita que a ética do líder seja fonte de cooperação e justiça, o impacto nos seguidores deve ocorrer na esfera do comportamento individual. Dessa maneira, neste estudo será utilizado o conceito de comportamento de cidadania organizacional individual, avaliando assim o comportamento de ajuda que os indivíduos apresentam em relação aos seus colegas de trabalho. 


\subsection{1. Liderança ética e Comportamento de cidadania organizacional}

$\mathrm{Na}$ literatura, alguns estudos analisaram a relação entre fatores da personalidade, atitudes no trabalho e o comportamento de cidadania organizacional. Características como conscienciosidade, cooperação, afetividade positiva ou negativa influenciam a orientação dos indivíduos no que concerne ao relacionamento com pares e gestores. Essas orientações seriam então responsáveis por conduzir suas atitudes de maneira solidária, justa e compromissada (ORGAN e RYAN, 1995).

O altruísmo pode ser traduzido como a "tendência permanente de pensar no bem estar e nos direitos de outras pessoas, de sentir preocupação e empatia por eles e agir de uma forma que os beneficia" (PENNER e KINKELSTEIN, 1998), dessa maneira, relaciona-se ao comportamento de ajuda, ao desejo voluntário de cooperar com as demais pessoas. Em um estudo de natureza quantitativa, foi verificada a relação positiva entre a atitude altruista e o comportamento de cidadania organizacional (EMMERIK, JAWAHAR eSTONE, 2005).

Este tipo de comportamento envolve o traço pró-social de personalidade, portanto, pensamentos, sentimentos e ações orientadas ao benefício de outras pessoas (PENER, MIDILI e KEGELMEYER, 1997). De maneira convergente, para que um líder seja reconhecido como ético e, para que possa exercer influência sobre atitudes éticasde seus seguidores, é fundamental que seja percebido como confiável e legítimo. Uma vez que os comportamentos dos líderes considerados éticos são guiados pela honestidade ealtruismo, são normativamente aceitos, podendo servir como alvo de identificação ou modelo de conduta ética (BROWN et al., 2005).

A percepção do funcionário sobre o tratamento justo no contexto organizacional se denomina justiça organizacional e está relacionada, dentre outros fatores, à distribuição de recompensas e processos utilizados na tomada de decisão que o afetem (PENNER et al, 1997). A justiça organizacional tem uma relação positiva com o comportamento de cidadania organizacional. A possível explicação para tal fenômeno é que, se os indivíduos percebem que são tratados de maneira justa, têm a tendência a contribuir com ações que promovam justiça (ORGAN, 1990 apud PENNER et al, 1997). 
Diferentes estilos de liderança incitam diferentes relacionamentos com seus seguidores, que por sua vez estabelecem formas diferenciadas de participação e contribuição ao sucesso organizacional. Os estilos de liderança com foco em relações interpessoais e redes sociais parecem estar associados com seguidores que possuem características de colaboração em grupo (GRAHAM, 1995).

O líder ético estabelece suas ações baseadas na honestidade, altruísmo e desenvolve relações baseadas na confiança de seus seguidores. É peculiar a característica denominada moral manager, que aponta para o esforço proativo dos gestores em influenciar o comportamento ético de seus subordinados através de mensagens explícitas carregadas de valor e sistemas de recompensa (TREVIÑO, BROWN e HARTMAN, 2003).

À medida que o líder ético apresenta este tipo de comportamento e pode ser um modelo de conduta para seus funcionários, é possível que o comportamento de ajuda e cooperação voluntária sejam consequentes deste estilo de liderança. Assim, é parte do objetivo deste estudo verificar se a liderança ética é um antecedente do comportamento de cidadania organizacional individual. Apresenta-se assim, a quarta hipótese do estudo:

H3: A liderança ética afeta positivamente o comportamento de cidadania organizacional individual (CCOi)

\subsection{2. LMX (Leader Member Exchange) e Comportamento de cidadania organizacional (CCO)}

Um dos temas que têm chamado a atenção de pesquisadores da área de liderança é como a percepção dos funcionário sem relação aos seus líderes influenciam seus pensamentos e comportamentos no trabalho. Podsakoff, Mackenzie, Moorman e Fetter (1990) analisaram os efeitos do comportamento dos líderes transformacionais na confiança, satisfação e comportamento de cidadania organizacional. Neste estudo, o efeito sobre a cidadania foi indireto, sendo moderado pela confiança no líder e satisfação com o trabalho.

A definição de Organ (1988) sobre a cidadania organizacional deixa claro que não há recompensa direta e/ou formal da organização em relação aos indivíduos que a pratiquem. Apesar disso, o autor aborda os efeitos indiretos 
acerca deste tipo de comportamento, que pode causar boas impressões aos colegas de trabalho, e ao gestor, tendo consequências como aumento salarial ou promoções.

Ao analisar os efeitos do carisma de líderes sobre os comportamentos de engajamento e cidadania organizacional, resultados apontam para a indicação que líderes carismáticos possuem equipes mais engajadas no trabalho e que promovem o comportamento de cidadania organizacional (BABCOCK-ROBERSON e STRICKLAND, 2010).

A troca entre líder e seguidores aparece como preditor do comportamento de cidadania organizacional com ênfase ao papel dos gestores que, com apoio e incentivo, desempenham o papel de influenciadores do comportamento que vai além do escopo de trabalho inicialmente definido (ISHAK e ALAM, 2009). Outros pesquisadores corroboraram esta ideia, como Asgari, Silong, Ahmad e Sama (2008), que avaliaram a relação de LMX como variável mediadora entre a liderança transformacional e o comportamento de cidadania organizacional (OCB). Embora a liderança apareça como uma variável influenciadora deste comportamento, a relação parece ser ainda mais forte quando mediada pela LMX, o que reafirma sua importância.

Ao analisar a literatura, Organ e Ryan (1995) identificaram a existência da relação entre o altruísmo e o suporte do líder como possíveis preditores do comportamento de cidadania organizacional. Como discutido anteriormente, o líder ético possui atitudes baseadas em valores como oaltruismo e a equidade. Também faz parte do perfil deste tipo de liderança desenvolver e auxiliar seus subordinados, reforçando comportamentos de caráter ético.

Assim, é esperado que a relação do líder com cada funcionário, individualmente, seja proveitosa de maneira que o liderado possa ser considerado por seu líder como um integrante "in group", ou seja, alvo de investimento em seu desenvolvimento e carreira. Por sua vez, o funcionário, sentindo-se parte integrante do grupo, estaria propenso a desenvolver um comportamento de ajuda com seus pares e líder, denominado, assim, cidadania organizacional.

Desta maneira, propõe-se a quinta hipótese deste estudo: 


\section{H4: A qualidade da relação dos líderes e seguidores (LMX - leader member exchange) afeta positivamente o comportamento de cidadania organizacional individual (OCBi)}

\section{6. \\ Comprometimento com a meta}

Uma vez que a motivação é reconhecidamente um tópico recorrente para pesquisadores e gestores (KLEIN, WESSON, HOLLENBECK e ALGE, 1999), o comprometimento com a meta se torna alvo de relevantes discussões quando o foco é atingir um melhor desempenho organizacional.

O comprometimento com a meta tem sido associado ao desempenho em diversos contextos e é caracterizado pela determinação em tentar atingir objetivos aliada à persistência em perseguí-los ao longo do tempo (KLEIN et al., 1999; WOFFORDet al., 1992).

Com base em críticas relacionadas a estudos anteriormente conduzidos, Klein e Kim (1998) defendem que além do bom relacionamento entre líder e funcionário influenciarem no desempenho individual, o comprometimento do funcionário com a meta é fundamental para o alcance do bom desempenho. Nessa perspectiva, o comprometimento com a meta é um conceito considerado crucial no que tange à teoria dos objetivos e alcance de resultados. O estabelecimento de metas especifícas e difíceis de serem alcançadas estão mais positivamente relacionadas com o desempenho quando comparadas àquelas com menor nível de dificuldade (LOCKE e LATHAM, 1990). Como é indicado por muitos estudos sobre a teoria dos objetivos, esta relação é mediada pelo comprometimento estabelecido pelo indivíduo com sua meta (KLEIN et al., 1999).

A literatura aponta para a existência de estudos que denotam particular relevância ao nível de comprometimento depositado para o desempenho de metas de difícil alcance (LATHAM, EREZe LOCKE, 1988). É importante ressaltar que o comprometimento com a meta funciona como variável mediadora nos casos em que a meta tem maior nível de dificuldade e, portanto, conta também com maior nível de comprometimento (KLEIN, WESSON, HOLLENBECK e ALGE, 1999).

Uma vez que o desempenho é indicado como um fator consequente do comprometimento com a meta, é relevante investigar os antecedentes que 
possivelmente afetam esta variável. Em uma metanálise realizada por Klein et al (1999), fatores pessoais são explicitamente relacionados como preditores do comprometimento com a meta. Expectativa, possibilidade de realização, habilidade e experiência, volição, emoção e locus de controle são algumas das características individuais relacionadas ao fato de se comprometer com maior afinco ao alcance da meta. Também são apresentados com relevância a este processo, fatores situacionais, como dificuldade, especificidade e complexidade da meta; presença e tipo de feedback; liderança e suporte da supervisão.

\subsection{1.}

\section{LMX e Comprometimento com a meta}

Embora alguns componentes tenham sido apontados previamente como antecedentes do comprometimento com a meta, o número de pesquisas que têm dedicado atenção a estes preditores ainda é escasso e não suficientemente sistematizado (KLEINet al., 1999). Embora ainda seja superficial o aprofundamento do impacto da liderança no comprometimento com a meta, Piccolo e Colquit (2006) encontraram relação positiva estabelecida entre o estilo de liderança e características do trabalho consideradas "core", dentre elas, o comprometimento com a meta. Segundo os autores, líderes com estilo de liderança transformacional teriam impacto positivo no comprometimento dos seguidores com suas metas. Outra indicação é que essa relação parece ser mediada pela qualidade da relação de troca entre líder-liderados (LMX), de maneira que os seguidores que percebem maior qualidade nessa relação podem estar mais abertos à influência social o que por sua vez reforça a confiança e comprometimento em seus líderes.

De maneira a ampliar a discussão do impacto da liderança no comprometimento com a meta dos seguidores, será alvo de investigação dessa pesquisa se a qualidade da relação entre líderes e seguidores tem influência no ato de comproter-se com a meta dos funcionários. Assim, apresenta-se a quinta hipótese deste estudo:

H5: A qualidade da relação dos líderes e seguidores (LMX - Leader Member Exchange) afeta positivamente o comprometimento com a meta. 


\section{3. Modelo da Pesquisa}

Apartir das hipóteses elaboradas, apresenta-se o modelo seguinte comoobjeto de estudo da presente pesquisa:

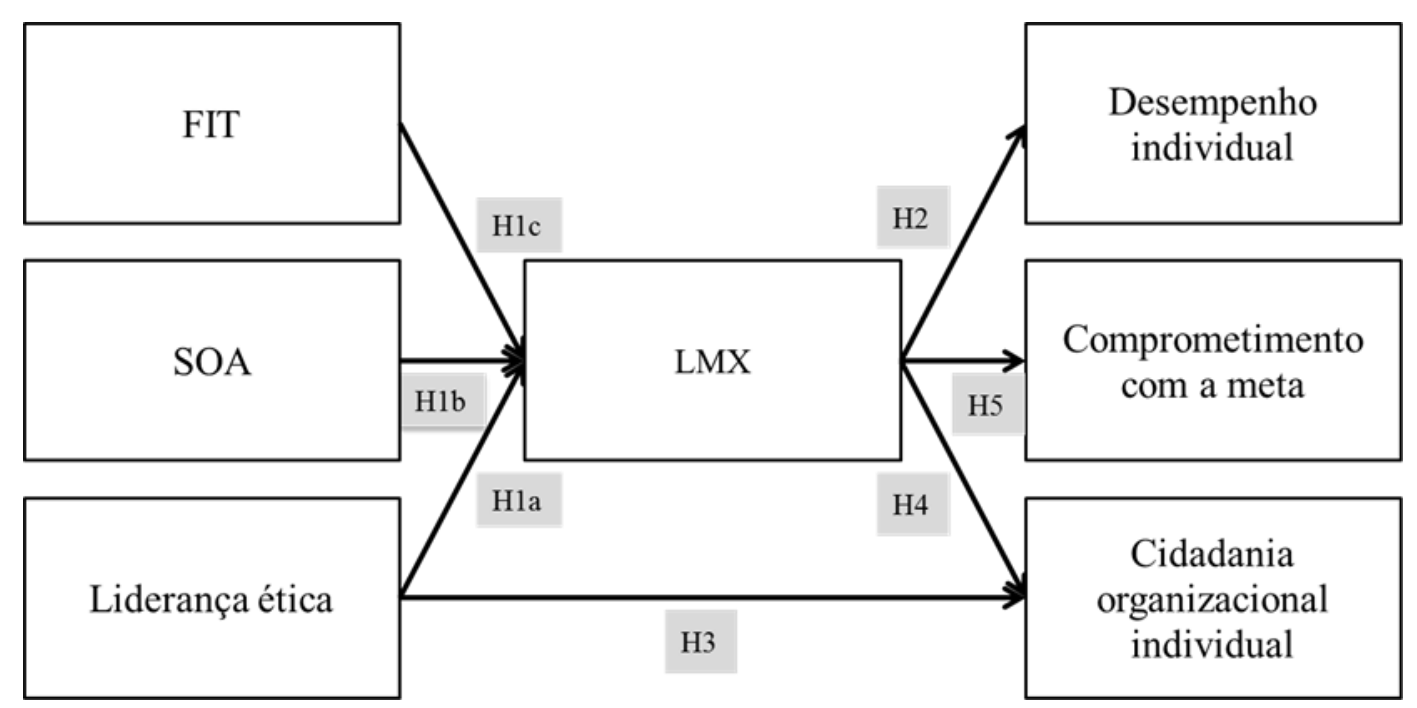

Nota: FIT é a congruência entre a ética do líder ea ética do subordinado; SOA é a congruência entreaautoavaliação ética do líder e a avaliação da ética do lídersegundo o subordinado

Figura 1: Modelo proposto

A partir do modelo propoposto, as seguintes hipóteses foram alvo de investigação:

H1a: A liderança ética, avaliada pela ótica dos seguidores, afeta positivamente a qualidade da relação de troca entre líder e liderado (LMX - Leader Member Exchange)

H1b: A congruência da liderança ética, avaliada pelo líder e seus seguidores (SOA), afeta positivamente a qualidade da relação de troca entre ambos (LMX - Leader Member Exchange)

H1c: O alinhamento da ética de líderes e seguidores (FIT) afeta positivamente a qualidade da relação de troca entre ambos (LMX Leader Member Exchange) 
H2: A qualidade da relação dos líderes e seguidores (LMX - Leader Member Exchange) afeta positivamente o desempenho individual H3: A liderança ética afeta positivamente o comportamento de cidadania organizacional individual (CCOi)

H4: A qualidade da relação dos líderes e seguidores (LMX - Leader Member Exchange) afeta positivamente o comportamento de cidadania organizacional individual $(\mathrm{OCBi})$

H5: A qualidade da relação dos líderes e seguidores (LMX - Leader Member Exchange) afeta positivamente o comprometimento com a meta. 


\section{4. \\ Metodologia}

Nesta seção são abordados os procedimentos metodológicos utilizados para o desenvolvimento do estudo: a amostra, a descrição dos meios de investigação, as técnicas utilizadas para análise dos dados e as limitações do método.

\section{1.}

\section{Universo e Amostra}

A população alvo deste estudo são vendedores de lojas de uma empresa multinacional de Telecomunicações com atuação no contexto brasileiro com cerca de 8.000 funcionários.

A amostra utilizada nestetrabalho foi selecionada por conveniência é não probabilística e foi composta por 161 funcionários, distribuídos entre as 17 lojas disponibilizadas pela empresa para realização da pesquisa.

O total de gerentes participantes foi 17 , dos quais 15 foram incluídos na análise do modelo, uma vez que não foi possível obter questionários de vendedores das equipes de dois dos gerentes de lojas do interior do estado.

\section{2.}

\section{Coleta de dados}

A coleta de dados ocorreu no período de junho a julho de 2013. Os participantes da pesquisa estão segmentados em dois grupos distintos: O grupo de gerentes e o de vendedores.

A pesquisa foi disponibilizada por meio de um questionário enviado por email para 230 vendedores e 17 gerentes de lojas. A identificação do gestor e seus respectivos funcionários foi realizada através de um código fornecido a cada vendedor, combinando números que identificavam a loja e letras que identificavam o vendedor. Especificamente para os vendedores, que não possuem acesso ao e-mail corporativo, o e-mail utilizado foi pessoal. 
Como o retorno obtido através dessa ferramenta foi insuficiente, apenas cerca de $6,5 \%$, a estratégia para realização da pesquisa foi redefinida, passando a ser realizada por questionários em papel. A autora da pesquisa visitou presencialmente 13 das 17 lojas participantes, o que proporcionou a participação de 161 vendedores respondentes. Devido à disponibilidade do e-mail como ferramenta de trabalho, a equipe de gerentes respondeu à pesquisa digitalmente.

No momento da aplicação da pesquisa, a pesquisadora realizava uma apresentação garantindo o sigilo dos dados e confidencialidade das informações no que se refere aos funcionários da referida organização. De maneira geral, a aplicação era realizada por equipes divididas em turnos (manhã e tarde), em horários destinados às refeições, ou anteriormente ao início das atividades.

\section{3. \\ Medidas e Instrumentos utilizados}

Os intrumentos utilizados foram elaborados de maneira diferente para os dois grupos considerados: vendedores e gerentes.

Para o grupo de vendedores, o questionário foi composto por 58 itens referentes às escalas que avaliam os construtos de interesse, e seis perguntas relacionadas aos dados demográficos. Os construtos levantados foram aautoavaliação no que diz respeito à ética (10 itens), a cidadania organizacional (14 itens), o comprometimento com a meta ( 7 itens), a desejabilidade social (10 itens), a avaliação do líder pelo funcionário no que concerne à ética (10 itens) e a avaliação pelo funcionário da relação entre líder-seguidor - LMX (7 itens).

Para o grupo de líderes, o instrumento foi composto por cinco perguntas referentes a dados demográficos, pela autoavaliação do líder no que diz respeito a ética (10 itens), pela desejabilidade social (10 itens) e a avaliação do líder sobre o desempenho individual de cada subordinado ( 7 itens/vendedor).

A descrição detalhada acerca dos instrumentos utilizados segue abaixo:

1- Ethical Leadership Scale (Escala de liderança ética - ELS) - desenvolvida por Brown, Treviño e Harrison (2005), é uma escala Likert de 7 pontos, composta por 10 itens, com Alpha de Cronbach de 0,92. O objetivo é 
avaliar a personalidade do líder no que diz respeito à ética, a sua interação e consideração de seus subordinados no que concerne à esta temática.

Assim, o gestor realiza uma autoavaliação relacionada à sua própria ética e, com o objetivo de ampliar a fidedignidade da variável minimizando o viés social, os funcionários avaliam seus líderes. Um dos itens, por exemplo, é: "Meu líder dá o exemplo de como fazer as coisas da maneira correta sob o ponto de vista ético". No que se refere àa esta amostra, o valor de Alpha observado foi 0,92.

Para atingir um dos objetivos propostos pelo estudo, comparar a ética dos líderes e subordinados, uma adaptação foi realizada ao instrumento de modo que os funcionários também realizem uma autoavaliação ética. Neste caso, o valor de Alpha observado foi 0,68.

2- Social Desirability Scale (Escala de desejabilidade social) - Foi utilizada uma versão reduzida de Strahan-Gerbasi da escala de Marlowe-Crowne. Instrumento com 10 itens, trata-se de uma escala Likert de 6 pontos, variando de 1 (Discordo totalmente) até 6 (Concordo totalmente). A utilização desta escala tem por objetivo controlar o viés social de resposta uma vez que o construto estudado é sensível e suscetível a este fenômeno. Em conversa com a gerente geral da área investigada ela apontou que a ética é um tema sensível e que a área possui indicadores de fraude.

3- Leader member exchange (LMX) - Escala desenvolvida por Bauer e Green (1996), tem o objetivo de avaliar a qualidade da relação entre líder e seguidor. É composta por 7 itens, dentre os quais, “O seu gestor compreende os seus problemas e necessidades no trabalho?”. O Alfa de Cronbach desta medida original é 0,90 .

4- Comportamento de cidadania organizacional individual - Desenvolvida por Williams e Anderson (1991), o instrumento é composto por 14 itens com escala Likert de sete pontos, sendo subdivididos em dois grupos: 7 itens que avaliam o comportamento na esfera individual (OCBi) e 7 itens que avaliam o comportamento no contexto organizacional (OCBo). Os valores do Alfa de Cronbach para cada uma delas são: 0,88 para OCBi e 0,75 para OCBo.

5- Comprometimento com a meta - instrumento de sete itens desenvolvido por Hollembeck, Williams e Klein (1989), é composto por uma escala 
Likert de 5 pontos variando de 1 (discordo totalmente) até 5 (concordo totalmente), a qual possui um Alfa de Cronbach de 0,80. Um exemplo desta escala é: "É difícil levar algumas de minhas metas a sério".

A consideração do comprometimento com a meta no modelo se refere à relevância deste fator para o melhor desempenho individual e ainda a ambragência na investigação de possíveis antecedentes. Neste caso, o relacionamento entre líder e seguidores.

6- Atingimento trimestral - De forma a contemplar o desempenho individual minimizando a restrição da métrica de desempenho (KLEIN e KIM, 1998), foram utilizadas informações fornecidas pela empresa referentes a métricas objetivas. $\mathrm{O}$ valor considerado na análise diz respeito à média do percentual de atingimento das metas de três meses consecutivos (fevereiro, março e abril).

7- Desempenho individual ou na tarefa (WILLIAMS e ANDERSON, 1991) Esta escala foi respondida por cada gerente, que avaliou cada funcionário de sua equipe individualmente. Trata-se de uma escala Likert de 7 pontos, variando de 1 (Discordo toralmente) até 7 (Concordo totalmente), o Alfa de Cronbach da métrica original é 0,91 .

Os estudos que envolvem desempenho se utilizam de métricas quantitativas, portanto, de caráter mais objetivo e mensuráveis e as qualitativas, mais focadas nas atitudes e comportamentos dos indivíduos (LUTHANS, AVOLIO, AVEY e NORMAN, 2007; WILLIAMS e ANDERSON, 1991). Como pressuposto para este estudo, a avaliação do desempenho individual considera a presença de métricas quantitativas e qualitativas.

Algumas variáveis demográficas e biográficas foram controladas para que possíveis influências nos resultados fossem monitorados.

a) Gênero - Uma vez que a cooperação e o altruismo são considerados valores predominantemente femininos (HOFSTEDE, 1980 apudORGAN e RYAN,1995) e a liderança ética se relaciona com estes valores, este dado será controlado. Somado a este fato, há indicações de que o sexo possa ser um moderador do comportamento de cidadania organizacional (ORGAN e RYAN, 1995). 
b) Idade

c) Tempo na empresa

d) Tempo de experiência em vendas

e) Tempo de subordinação ao líder atual

f) Tempo no cargo de liderança na empresa atual 


\section{5. \\ Análise dos Dados e Resultados}

Neste capítulo serão elucidadas as análises realizadas a partir dos dados e resultados estatísticos, assim como a correspondência com as hipóteses inicialmente elaboradas.

\section{1.}

\section{Caracterização da amostra}

A amostra final deste estudo foi composta por 161 vendedorese 15 gerentes de loja. Em relação aos vendedores, 54\% são mulheres e $46 \%$ são homens; a idade média é de 28 anos, sendo 19 a mínima e 44 anos a máxima. No que se refere ao grau de instrução, o tempo médio de Escolaridade é 13,96 anos; especificamente, 27,32\% possuem Ensino Médio, 49,06\%, Ensino Superior inclompleto, 21,73\%, Ensino Superior Completo e 2,48\%, Pós Graduação. O tempo médio de experiência com vendas é de 5,48 anos e o tempo médio na empresaé de 4,85 anos.

Acerca dos gerentes de loja, 53,33\% são mulheres e 46,66\% são homens; a idade média é de 32 anos, sendo 26 a mínima e 43 a máxima. Quanto ao grau de instrução, o tempo médio de Escolaridade é de cerca de 15 anos; 33,33\% com Ensino Superior inclompleto, 53,33\% com Ensino Superior completo e 13,33\% com Pós Graduação. O tempo médio na empresa é de 6,5 anos e o tempo médio no cargo de liderança na empresa é de 2,4 anos.

\begin{tabular}{|l|c|c|}
\cline { 2 - 3 } \multicolumn{1}{c|}{} & Vendedores & Gerentes \\
\hline Mulheres & $54 \%$ & $53,33 \%$ \\
\hline Homens & $46 \%$ & $46,66 \%$ \\
\hline Tempo Escolaridade* & 13,96 anos & 15 anos \\
\hline Idade* $^{*}$ & 28 anos & 32 anos \\
\hline Tempo empresa* $^{*}$ & 4,85 anos & 6,5 anos \\
\hline Tempo Exp. Vendas* & 5,48 anos & -- \\
\hline Tempo Liderança* & -- & 2,4 anos \\
\hline
\end{tabular}

* Utilização do valor médio

Tabela 3: Dados demográficos 


\section{2.}

\section{Análise descritiva}

Para a realização dos cálculos e análise dos dados, foi utilizado o software estatístico SPSS. Devido à existência de múltiplos itens nas escalas, foram calculadas médias correspondentes a cada construto investigado.

A fim de traçar o perfil da amostra estudada, a primeira análise estatística realizada foi descritiva das variáveis o que gera como resultado todas as médias, desvio padrão e correlações entre as variáveis presentes no estudo. Também foram realizadas análises de confiabilidade das escalas utilizadas, que são representadas na tabela 4 .

\begin{tabular}{|c|c|c|c|c|c|c|c|c|c|c|c|c|c|c|c|c|}
\hline Variável & Média & DP & 1 & 2 & 3 & 4 & 5 & 6 & 7 & 8 & 9 & 10 & 11 & 12 & 13 & 14 \\
\hline 1. Sexo & 1,46 &, 50 & -- & & & & & & & & & & & & & \\
\hline 2.Idade & 28,24 & 4,68 &,- 11 & -- & & & & & & & & & & & & \\
\hline 3.Es colaridade & 13,96 & 1,50 &, 07 &, $20 * *$ & -- & & & & & & & & & & & \\
\hline 4. Experiência vendas & 5,48 & 2,83 & ,04 &, $41 * *$ &, $19 *$ & -- & & & & & & & & & & \\
\hline 5. Tempo na empresa & 4,85 & 2,51 &,- 01 &, $46^{* *}$, & $26 * *$ & $33 * *$ & -- & & & & & & & & & \\
\hline 6. Tempo subordinação & ,88 &, 48 &, 15 &,$- 17 * *$ &,- 14 &,- 01 &,- 00 & -- & & & & & & & & \\
\hline 7. $\mathrm{CCO}$ & 4,19 &, 26 &,- 08 &, 02 &,- 10 & 04 &, 07 &,- 02 & $(0,51)$ & & & & & & & \\
\hline 8. Ética subordinado & 6,20 &, 52 &,- 03 &, $19^{*}$ &, 13 &, 14 & 0,12 &, 05 &, $39 * *$ & $(0,68)$ & & & & & & \\
\hline 9. LMX & 3,62 &, 71 &, 09 & ,03 &,- 00 &, 00 &,- 08 &, 14 &, 11 &, $17 *$ & $(0,85)$ & & & & & \\
\hline 10. Ética Líder (av.subordinado) & 5,80 & 1,10 &, 15 &, 10 &, 03 & 04 &, 01 &, 05 & 15 & $24 * *$ & ,74** & $(0,92)$ & & & & \\
\hline 11. Desejabilidade social & 3,84 &, 78 &,- 03 &, $26 * *$ &,- 07 &, $16^{*}$ &, 06 &, 09 &, $20 *$ & $25 * *$ & ,28**, & $23 * *($ & $0,66)$ & & & \\
\hline 12. Desempenho & 3,79 &, 86 &, 07 &, $17^{*}$ & ,02 &,- 03 &, 15 &, 11 &, 10 &, 12 & ,23** &, 14 &, 14 & $(0,90)$ & & \\
\hline 13. Comprometimento meta & 2,09 & ,69 & ,09 &, 08 &, 14 &, 02 &, $21 * *$ &, 04 &,- 11 &,- 12 & $-29 * *$ &,$- 19 *$ &,- 08 &,- 14 & $(0,65)$ & \\
\hline 14. Atingimento meta &, 77 &, 16 &, 04 &, 02 &, 12 &,- 10 &, 00 &,- 06 &, 04 &,- 10 &,- 10 &,- 03 &,- 04 &, 11 &, 03 & -- \\
\hline
\end{tabular}

Tabela 4: Médias, Desvios-Padrão, Correlações e Alphas de Cronbach

Embora de uma maneira geral os alphas apresentados sejam satisfatórios, o alpha de cidadania organizacional requer atenção. Enquanto os alphas da escala original de cidadania organizacional é de 0,88 para CCOie 0,75 para CCO global, o alpha encontrado neste estudo para a escala de cidadania organizacional individual é de 0,51. Uma possível explicação para este fato pode indicar falta de compreensão ou de sentido dos itens para a população estudada. A especificidade da natureza do trabalho de vendas realizado nas lojas pode apresentar algum tipo de desvio ao que a escala se propõe a mensurar.

Foram realizadas análises para avaliação das premissas da análise de regressão relacionadas aos diagramas deresíduos e gráficos de normalidade (BLACK, 2010). Os resultados apontaram para a não violação das condições de 
normalidade, homocedasticidade, linearidade e independência dos resíduos; com exceção da variável de cidadania organizacional individual que demonstrou assimetria. Como reportado anteriormente, a mensuração desse construto será tratada como uma limitação do presente estudo.

\section{3.}

\section{Análise de hipóteses}

Para a análise das hipóteses propostas, foram realizadas regressões múltiplas, com diferentes variáveis dependentes de maneira a explorar o modelo proposto. No que se refere à hipótese 1, relativa aos antecedentes de LMX (Tabela 4), a primeira análise contou com a realização de uma regressão múltipla para investigar o efeito direto da liderança ética (na ótica do seguidor) na qualidade da relação de LMX - relação de troca líder/liderado. Nessa análise, foi incluída a variável desempenho do subordinado (na avaliação do líder) como preditora do LMX, e, para fins de controle, variáveis demográficas (idade, sexo, escolaridade) e biográficas (experiência em vendas, tempo na empresa). O modelo 1, composto apenas pelas variáveis de controle não foi estatisticamente significativo.

O modelo 2, que inclui as variáveis biográficas e o desempenho individual, foi estatisticamente significativo, com coeficiente de determinação capaz de explicar $8 \%$ da variável LMX $\left(\mathrm{R}^{2}=0,08, \mathrm{p}<0,01\right)$. Isso denota que a visão do líder sobre o desempenho individual do subordinado interfere no relacionamento entre líder-liderado (LMX) (avaliado sob a perspectiva do seguidor). Como pode ser verificado, o coeficiente de regressão da variável desempenho foi significativo ( $\beta$ $=0,24 ; \mathrm{t}=2,99 ; \mathrm{p}<0,01)$. O modelo inclui a variável de maior interesse, a ética do líder sob a ótica de seu subordinado que nessa análise foi estatisticamente significativa, com alta magnitude $\left(\mathrm{R}^{2}=0,58, \mathrm{p}<0,001\right)$. Esta análise sugere que a percepção do subordinado sobre uma liderança ética e o seu próprio desempenho são capazes de explicar 58\% da variância na qualidade do relacionamento entre líderes e seus subordinados.Neste caso, o coeficiente de regressão da ética do líder demonstrou ser significativo $(\beta=0,73 ; \mathrm{t}=13,57 ; \mathrm{p}<0,001)$. Este resultado confirma a primeira hipótese do modelo proposto, H1a: A liderança ética, avaliada pela ótica dos seguidores, afeta positivamente a qualidade da relação de troca entre líder e liderado (LMX - leader member exchange). 


\begin{tabular}{|c|c|c|c|c|c|c|}
\hline \multirow[t]{2}{*}{ Variáveis } & \multicolumn{2}{|c|}{$\begin{array}{c}\text { Modelo } 1 \text { - } \\
\text { Demográficos }\end{array}$} & \multicolumn{2}{|c|}{$\begin{array}{l}\text { Modelo } 2 \text { - } \\
\text { Biográficos }\end{array}$} & \multicolumn{2}{|c|}{ Modelo 3 - Lid. Ética } \\
\hline & $\beta$ & $\mathrm{t}$ & $\beta$ & $\mathrm{t}$ & $\beta$ & $\mathrm{t}$ \\
\hline Idade & 0,04 & 0,52 & 0,05 & 0,50 & $-0,03$ & $-0,51$ \\
\hline Sexo & 0,10 & 1,22 & 0,08 & 0,97 & $-0,04$ & $-0,65$ \\
\hline Escolaridade & $-0,01$ & $-0,17$ & 0,01 & 0,17 & 0,01 & 0,12 \\
\hline vendas & & & 0,04 & 0,41 & 0,02 & 0,38 \\
\hline Tempo na empresa & & & $-0,15$ & $-1,64$ & $-0,10$ & $-1,68$ \\
\hline Desempenho & & & 0,24 & $2,99 * *$ & 0,15 & $2,78 * *$ \\
\hline \multicolumn{3}{|c|}{ Ética Líder (av.subordinado) } & & & 0,73 & $13,57 * * *$ \\
\hline $\mathbf{R}^{2}$ & 0,01 & & $0,08^{* *}$ & & $0,58^{* * * *}$ & \\
\hline$R^{2}$ aj. & $-0,01$ & & $0,04 * *$ & & 0,56 **** & \\
\hline$\Delta \mathbf{R}^{2}$ & 0,01 & & $0,07 * *$ & & $0,51 * * *$ & \\
\hline
\end{tabular}

Nota: $\mathrm{N}=161$;

$* * p<0,01 * * * p<0,001$

Tabela 5: Regressão Múltipla - Preditores de LMX (perspectiva do subordinado)

Com o objetivo de analisar os preditores do desempenho individual, duas regressões foram realizadas: a primeira, considerando o desempenho a partir de métricas objetivas, isto é, a média do percentual de atingimento trimestral; a segunda, considerando o desempenho avaliado pelos líderes. A primeira regressão não demonstrou ser estatisticamente significativa com nenhum aspecto demográfico ou biográfico, LMX e ética do líder. Isso significa que a ética do líder avaliada pelo subordinado e o relacionamento estabelecido entre eles aparentemente não estão relacionadas ao atingimento trimestral das metas.

A segunda regressão também foi realizada considerando as variáveis existentes nos três modelos anteriores: demográfico, biográfico e liderança ética. O modelo 1, composto pelos dados demográficos (sexo, idade e escolaridade) foi significativo no que tange à idade, quanto maior a idade dos vendedores, melhor a avaliação de desempenho correspondente. Já o modelo 2, composto pelos dados biográficos (experiência em vendas, tempo na empresa) como precedentes do desempenho, não foiestatisticamente significativo. O terceiro modelo, no entanto, se apresentou estatisticamente significativo, explicando $12 \%$ da variância $\left(\mathrm{R}^{2}=\right.$ $0,12, \mathrm{p}<0,01)$. A variável independente LMX apresentou um coeficiente de regressão tambémsignificativo $(\beta=0,32 ; \mathrm{t}=2,78 ; \mathrm{p}<0,01)$. Este resultado sugere 
que a qualidade dorelacionamento ente líder e seguidor (avaliação do LMX na perspectiva do subordinado) influencia positivamente o desempenho individual (na perspectiva do gestor) confirmando a segunda hipótese do presente estudo: $A$ qualidade da relação dos líderes e seguidores (LMX - leader member exchange) afeta positivamente o desempenho individual.

\begin{tabular}{|c|c|c|c|c|c|c|}
\hline \multirow[t]{2}{*}{ Variáveis } & \multicolumn{2}{|c|}{$\begin{array}{c}\text { Modelo } 1 \text { - } \\
\text { Demográficos }\end{array}$} & \multicolumn{2}{|c|}{$\begin{array}{l}\text { Modelo } 2 \text { - } \\
\text { Biográficos }\end{array}$} & \multicolumn{2}{|c|}{ Modelo 3 - Lid. Ética } \\
\hline & $\beta$ & $\mathrm{t}$ & $\beta$ & $\mathrm{t}$ & $\beta$ & $\mathrm{t}$ \\
\hline Sexo & 0,10 & 1,21 & 0,10 & 1,30 & 0,09 & 1,15 \\
\hline Idade & 0,19 & $2,32 *$ & 0,20 & 2,11 & 0,19 & 1,99 \\
\hline Escolaridade & $-0,03$ & $-0,32$ & $-0,03$ & $-0,36$ & $-0,03$ & $-0,39$ \\
\hline vendas & & & $-0,14$ & $-1,62$ & $-0,14$ & $-1,67$ \\
\hline Tempo na empresa & & & 0,11 & 1,15 & 0,14 & 1,55 \\
\hline \multicolumn{5}{|c|}{ Ética Líder (av.subordinado) } & $-0,12$ & $-1,05$ \\
\hline \multicolumn{5}{|l|}{ LMX } & 0,32 & $2,78 * *$ \\
\hline $\mathbf{R}^{2}$ & 0,04 & & 0,06 & & $0,12 * *$ & \\
\hline $\mathbf{R}^{2}$ aj. & 0,02 & & 0,03 & & $0,08 * *$ & \\
\hline$\Delta \mathbf{R}^{2}$ & 0,04 & & 0,02 & & $0,06^{* *}$ & \\
\hline
\end{tabular}

Nota: $N=161$;

$* \mathrm{p}<0,05 * * \mathrm{p}<0,01$

Tabela 6: Regressão Múltipla - Preditores Desempenho (sob ótica do líder)

Para avaliar a terceira e quarta hipótese desse estudo (Tabela 6), que dizem respeito ao impacto de LMX e da liderança ética no comportamento de cidadania organizacional individual, foi realizada nova regressão múltipla, com dois modelos, tendo como variáveis independentes o LMX e a liderança ética (na avaliação do subordinado). Para fins de controle, foram incluídos nessa análise fatores demográficos (sexo, idade e escolaridade). O primeiro modelo demonstrou ser estatisticamente significativo capaz de explicar $4 \%$ da variância do comportamento de cidadania organizacional $\left(\mathrm{R}^{2}=0,04, \mathrm{p}<0,05\right)$, com um coeficiente de regressão significativo para ética do líder $(\beta=0,18 ; \mathrm{t}=2,18$; $\mathrm{p}<$ 0,05). No segundo bloco, é incorporada a variável LMX à regressão, porém esse acréscino não alterou a capacidade explicativa do modelo, concluindo-se que a variável acrescentada não é relevante na previsão da cidadania organizacional individual. A análise dessa regressão sugere que há um efeito significativo da liderança ética (avaliação do subordinado) diretamente relacionada ao 
comportamento de cidadania organizacional individual o que confirma a terceira hipótese alvo dessa pesquisa: A liderança ética afeta positivamente o comportamento de cidadania organizacional individual (CCOi). Em contrapartida, na amostra investigada, o efeito da qualidade da relação entre líder e subordinado sobre o comportamento de cidadania não é observado o que significa rejeitar a quarta hipótese deste estudo: A qualidade da relação dos líderes e seguidores (LMX - leader member exchange) afeta positivamente o comportamento de cidadania organizacional individual (OCBi).

\begin{tabular}{|c|c|c|c|c|}
\hline \multirow[t]{2}{*}{ Variáveis } & \multicolumn{2}{|c|}{ Modelo 1 - Lid.Ética } & \multicolumn{2}{|c|}{ Modelo 2- LMX } \\
\hline & B & $\mathrm{t}$ & $\beta$ & $\mathrm{t}$ \\
\hline Sexo & $-0,01$ & $-0,11$ & $-0,01$ & $-0,09$ \\
\hline Idade & 0,03 & 0,36 & 0,03 & 0,38 \\
\hline Escolaridade & $-0,11$ & $-1,36$ & $-0,11$ & $-1,35$ \\
\hline Ética Líder(av.subordinado) & 0,18 & $2,18^{*}$ & 0,14 & 1,20 \\
\hline LMX & & & 0,04 & 0,35 \\
\hline $\mathbf{R}^{2}$ & $0,04 *$ & & 0,04 & \\
\hline $\mathbf{R}^{2} \mathbf{a j}$ & $0,01^{*}$ & & 0,01 & \\
\hline$\Delta \mathbf{R}^{2}$ & $0,02 *$ & & 0,00 & \\
\hline
\end{tabular}

Nota: $\mathrm{N}=161 ; * \mathrm{p}<0,05$

Tabela 7: Regressão Múltipla - Preditores Cidadania organizacional individual

Para análiseda hipótese 5 (Tabela 8), foi realizada nova regressão. No primeiro modelo, foram incluídos simultaneamente variáveis de controle demográficas e biográficas (idade, sexo, escolaridade, experiência em vendas e tempo na empresa) com a finalidade de verificar se alguma delas teria um efeito estatisticamente significativo, o que não foi observado. Em seguida, a inclusão da variável LMX no modelo 2 fez com que o modelo se tornasse estatisticamente significativo, explicando $15 \%$ da variância do comprometimento com a meta $\left(\mathrm{R}^{2}\right.$ $=0,15, \mathrm{p}<0,01)$. A variável LMX apresenta um coeficiente de regressão $(\beta=-$ $0,31 ; \mathrm{t}=-2,73 ; \mathrm{p}<0,01)$, trata-se de uma escala que dimensiona a falta de comprometimento, quanto menor a pontuação, mais comprometido com a meta é o funcionário. Assim, o caráter negativo do coeficiente de LMX indica que quanto maior a qualidade do relacionamento entre líder-liderado maior é o comprometimento com a meta, corroborando assim, a quinta hipótese desse estudo: A qualidade da relação dos líderes e seguidores (LMX - leader member exchange) afeta positivamente o comprometimento com a meta. 


\begin{tabular}{|c|c|c|c|c|}
\hline \multirow[t]{2}{*}{ Variáveis } & \multicolumn{2}{|c|}{$\begin{array}{c}\text { Modelo 1: Demográficos e } \\
\text { biográficos }\end{array}$} & \multicolumn{2}{|c|}{ Modelo 2: LMX } \\
\hline & $\beta$ & $\mathrm{t}$ & $\beta$ & $\mathrm{t}$ \\
\hline Idade & 0,09 & 1,19 & 0,12 & 1,62 \\
\hline Sexo & 0,01 & 0,06 & 0,04 & 0,39 \\
\hline Escolaridade & 0,09 & 1,14 & 0,09 & 1,20 \\
\hline Experiência em vendas & $-0,08$ & $-0,86$ & $-0,08$ & $-0,90$ \\
\hline Tempo na empresa & 0,21 & 2,29 & 0,17 & 1,93 \\
\hline LMX & & & $-0,31$ & $-2,73 * *$ \\
\hline $\mathbf{R}^{2}$ & $0,06^{*}$ & & $0,15^{* *}$ & \\
\hline $\mathbf{R}^{2} \mathbf{a j}$ & $0,03^{*}$ & & $0,11 * *$ & \\
\hline$\Delta \mathbf{R}^{2}$ & $0,03^{*}$ & & $0,04 * *$ & \\
\hline
\end{tabular}

Nota: $\mathrm{N}=161 ; * * \mathrm{p}<0,01$

Tabela 8: Regressão Múltipla - Preditores Comprometimento com a meta

\subsection{1.}

\section{Análise FIT e SOA}

Por fim, foi realizado um levantamento da literatura com a finalidade de avaliar qual seria o método estatístico mais adequado para a análise das hipóteses H1b e H1c que dizem respeito ao FIT e SOA, que envolvem a análise de congruência como preditora de uma variável de interesse. O FIT e o SOA têm a particularidade de apurar a congruência de um mesmo fator por dois elementos distintos, o líder e o subordinado. No caso do FIT, a análise da congruência se refere à ética do líder e a do seguidor. No caso do SOA, a análise da congruência se refere á ética do líder na visão dele mesmo e na visão do subordinado. Durante décadas, os estudos utilizaram a diferença de pontuações de dois construtos para análise da congruência (fit, similaridade) como preditor de algum resultado. Este método, no entanto, tem sido alvo de críticas por apresentar numerosos e substantivos problemas metodológicos. Uma análise estatística que ampliaria as limitações da anterior, considerando diferentes dimensões é a regressão polinomial, amplamente utilizada nos últimos anos (EDWARDS e PARRY, 1993).

Dessa forma, não é surpreendente que a literatura apresenteuma variedade de métricas nas análises estatísticas desses construtos. As diferentes formas de operacionalizar essas análises são um obstáculo à fidedignidade das conclusões dos estudos (FLEENOR, SMITHER, ATWATER, BRADDY e STURM; 2010). 
Nas hipóteses do presente estudo, a variável dependente considerada é LMX e as variáveis independentes são FIT e SOA. De maneira a elucidar os dois métodos de análise estatística, foi realizada a regressão polinomial além da análise da diferença de pontuação.

Na diferença de pontuação, os cálculos do FIT e SOA, respectivamente, foram: Autoavaliação da ética do líder subtraída da autoavaliação da ética do subordinado; Ética do líder na avaliação do subordinado subtraida da ética do líder na avaliação do líder.

A partir da regressão utilizando a diferença de "scores" (Tabela 9), é possível verificar que o primeiro modelo, com os dados demográficos e biográficos não apresentou relevância estatística. $\mathrm{O}$ segundo modelo também não é estatisticamente significativo, demonstrando que o FIT, ou seja, a congruência entre as éticas do líder e subordinado em suas próprias autoavaliações não interfere positivamente sobre a qualidade da relação entre eles, assim, com base nesse resultado, a hipótese H1c foi rejeitada. No que se refere ao modelo 3, que incluiu o SOA, os resultados foram altamente significativos. O coeficiente de regressão do SOA foi significativo $(\beta=-0,68 ; \mathrm{t}=-11,05 ; \mathrm{p}<0,001)$ explicando $46 \%$ da variância do $\operatorname{LMX}\left(\mathrm{R}^{2}=0,46, \mathrm{p}<0,001\right)$. Assim, a congruência entre a ética do líder na avaliação do próprio líder e a ética do líder na avaliação do subordinado é substancialmente importante na condução de um relacionamento de maior qualidade entre ambos (LMX).Dessa maneira, a hipótese H1b foi corroborada. 


\begin{tabular}{|c|c|c|c|c|c|c|}
\hline \multirow[t]{2}{*}{ Variáveis } & \multicolumn{2}{|c|}{$\begin{array}{l}\text { Modelo } 1 \text { - } \\
\text { Demográficos e } \\
\text { biográficos }\end{array}$} & \multicolumn{2}{|c|}{ Modelo 2 - FIT } & \multicolumn{2}{|c|}{ Modelo 3- FIT e SOA } \\
\hline & B & $\mathrm{t}$ & $\beta$ & $\mathrm{t}$ & $\beta$ & $\mathrm{t}$ \\
\hline Sexo &, 11 & 1,40 &, 12 & 1,48 &, 01 & ,20 \\
\hline Idade &, 11 & 1,10 &, 10 & 1,01 & ,02 &, 30 \\
\hline Escolaridade &, 01 &, 17 &, 01 &, 16 & ,02 &, 34 \\
\hline Experiência em vendas & 00 &,- 01 &,- 01 &,- 06 &, 01 &, 10 \\
\hline Tempo na empresa &,- 13 & $-1,44$ &,- 12 & $-1,30$ &,- 04 &,- 62 \\
\hline FIT & & &,- 08 & $-1,00$ &, 06 & ,99 \\
\hline SOA & & & & &,- 68 & $-11,05 * * *$ \\
\hline $\mathbf{R}^{2}$ & 0,03 & & 0,03 & & $0,46^{* * *}$ & \\
\hline $\mathbf{R}^{2}$ aj. & 0,00 & & 0,00 & & $0,43 * * *$ & \\
\hline$\Delta \mathbf{R}^{2}$ & 0,01 & & 0,01 & & $0,43 * * *$ & \\
\hline
\end{tabular}

Nota: $\mathrm{N}=161$;

$* * * \mathrm{p}<0,001$

Tabela 9: Regressão Múltipla - Preditores de LMX (SOA e FIT)

Como indicado por Edwards (1994), a análise da regressão Polinomial apresenta um resultado diferente do anteriormente relacionado.

A análise da regressão polinomial possibilita uma análise tridimensional para avaliação da congruência entre variáveis e seus efeitos nos resultados de outras variáveis (EDWARDS e PARRY, 1993). O procedimento seguido para realização da regressão requer o LMX como variável dependente e, as variáveis dependentes são diferentes para o FIT e SOA. Ambos os casos, trabalha-se com o produto das variáveis de ética e o quadrado das referidas variáveis. Com o objetivo de reduzir a multicolinearidade e facilitar a interpretação dos resultados, as variáveis são centralizadas.

Dessa forma, para o FIT os termos utilizados são: quadrado da autoavaliação ética do líder, quadrado da autoavaliação ética do seguidor eproduto da autoavaliação ética do líder pela autoavaliação ética do seguidor. O modelo 1 , que contém apenas os dados demográficos, não é estatisticamente significativo, o segundo, que inclui desempenho e as variáveis demográficas apresenta relevância com a variável desempenho com um coeficiente de regressão $(\beta=0,24 ; \mathrm{t}=2,99$; $\mathrm{p}<0,01)$, explicando $8 \%$ da variância do $\operatorname{LMX}\left(\mathrm{R}^{2}=0,08, \mathrm{p}<0,01\right)$, como demonstrado nos modelos analisados anteriormente.

O modelo 3, que avalia o FIT como preditor de LMX, alvo da hipótese H1c, apresenta o desempenho $(\beta=0,25 ; \mathrm{t}=3,61 ; \mathrm{p}<0,001)$ e a autoavaliação 
ética do líder $(\beta=-0,52 ; \mathrm{t}=-7,58 ; \mathrm{p}<0,001)$ como preditores de LMX. Para que o efeito da congruência (FIT) realmente exista, os coeficientes das três variáveis devem ser significativos. Dessa forma, as três variáveis (Autoavaliação ética líder $^{2}$, Autoavaliação ética seguidor ${ }^{2}$ e o produto da ética do líder e subordinado) deveriam ser estatisticamente significativos.

Com o resultado apresentado, é possível verificar que, para a amostra em questão, a congruência das autoavaliações éticas (FIT) de líderes e seguidores nãoé um preditor de uma relação de maior qualidade entre eles, o que nos faz rejeitar a hipótese H1c utilizando o método mais conservador da análise polinomial. No modelo apresentado, embora a autoavaliação ética do líder apareça como uma variável relevante, os demais fatores da análise polinomial do FIT não foram significativos.

\begin{tabular}{|c|c|c|c|c|c|c|}
\hline \multirow[t]{2}{*}{ Variáveis } & \multicolumn{2}{|c|}{$\begin{array}{c}\text { Modelo } 1 \text { - } \\
\text { Demográficos }\end{array}$} & \multicolumn{2}{|c|}{$\begin{array}{l}\text { Modelo } 2 \text { - } \\
\text { Desempenho }\end{array}$} & \multicolumn{2}{|c|}{ Modelo 3 - FIT } \\
\hline & $\beta$ & $\mathrm{t}$ & $\beta$ & $\mathrm{T}$ & $\beta$ & $\mathrm{t}$ \\
\hline Idade & ,04 &, 52 &, 05 & ,50 &, 00 &, 00 \\
\hline Sexo &, 10 & 1,22 & ,08 & 97 & ,01 & ,08 \\
\hline Escolaridade &,- 01 &,- 16 &, 01 &, 17 & ,00 &, 04 \\
\hline Experiência em vendas & & &, 04 &, 41 &, 11 & 1,42 \\
\hline Tempo na empresa & & &,- 15 & $-1,64$ &,- 12 & $-1,59$ \\
\hline Desempenho & & & ,24 & $2,99 * *$ & ,25 & $3,61 * * *$ \\
\hline autoav. ética líder ${ }^{2}$ & & & & &,- 52 & $-7,58 * * *$ \\
\hline autoav. ética seguidor ${ }^{2}$ & & & & &, 03 &, 49 \\
\hline Ética líder x Ética seguidor & & & & &,- 11 & $-1,67$ \\
\hline $\mathbf{R}^{2}$ & 0,01 & & $0,08 * *$ & & $0,34 * * *$ & \\
\hline $\mathbf{R}^{2}$ aj. & 0,01 & & $0,04 * *$ & & $0,30 * * *$ & \\
\hline$\Delta \mathbf{R}^{2}$ & 0,01 & & $0,07 * *$ & & $0,26 * * *$ & \\
\hline
\end{tabular}

Nota: $\mathrm{N}=161$

$* * \mathrm{p}<0,01 * * * \mathrm{p}<0,001$

Tabela 10: Regressão preditores LMX - FIT

Para o SOA, os termos são: Autoavaliação ética do líder ${ }^{2}$, Ética líder avaliação seguidores ${ }^{2}$ e o produto da autoavaliação ética do líder e ética líder na avaliação de seguidores.

O modelo 3, que avalia o SOA como preditor de LMX (Tabela 11), alvo da hipótese H1b, apresenta o desempenho $(\beta=0,25 ; \mathrm{t}=3,57 ; \mathrm{p}<0,001)$ e a avaliação ética do líder segundo o subordinado $(\beta=-0,50 ; \mathrm{t}=-6,37 ; \mathrm{p}<0,001)$ 
como preditores de LMX. No entanto, para que o efeito da congruência (SOA) seja confirmado, os coeficientes das três parcelas do polinômio devem ser significativos. Dessa forma, as três variáveis (Autoavaliação ética líder², Avaliação ética do líder segundo seguidor ${ }^{2}$ e o produto da autoavaliação ética do líder e avaliação ética do líder segundo subordinado) deveriam ser estatisticamente significativos.

Com o resultado obtido, é possível verificar que, para a amostra em questão, a congruência entre a autoavaliação ética do líder e a avaliação da ética do líder na perspectiva do seguidor não esteve associada a uma relação de maior qualidade entre eles, o que nos faz rejeitar a hipótese $\mathrm{H} 1 \mathrm{~b}$ pelo método mais conservador da análise polinomial. Porém, no modelo analisado é possível verificar que a avaliação ética do líder pelo seguidor é uma variável relevante, o que reforça a ideia de que a conduta do superior na ótica do subordinado é importante para o estabelecimento de um bom relacionamento, independente da ética do próprio seguidor.

\begin{tabular}{|c|c|c|c|c|c|c|}
\hline \multirow[t]{2}{*}{ Variáveis } & \multicolumn{2}{|c|}{$\begin{array}{l}\text { Modelo } 1 \text { - } \\
\text { Demográficos }\end{array}$} & \multicolumn{2}{|c|}{$\begin{array}{l}\text { Modelo } 2 \text { - } \\
\text { Desempenho }\end{array}$} & \multicolumn{2}{|c|}{ Modelo 3 - SOA } \\
\hline & $\beta$ & $\mathrm{t}$ & $\beta$ & $\mathrm{T}$ & $\beta$ & $\mathrm{t}$ \\
\hline Idade & ,04 & ,52 & ,05 & ,50 & ,01 & ,16 \\
\hline Sexo &, 10 & 1,22 & ,08 & 97 & ,01 & ,09 \\
\hline Escolaridade &,- 01 &,- 16 & ,01 & , 17 & ,02 & ,29 \\
\hline Experiência em vendas & & & ,04 & ,41 & ,09 & 1,13 \\
\hline Tempo na empresa & & &,- 15 & $-1,64$ &,- 09 & $-1,05$ \\
\hline Desempenho & & & ,24 & $2,99 * *$ &, 25 & $3,57 * * *$ \\
\hline Autoav. ética líder ${ }^{2}$ & & & & &,- 12 & $-1,60$ \\
\hline Ética líder av. seguidor ${ }^{2}$ & & & & &,- 50 & $-6,37 * * *$ \\
\hline $\begin{array}{l}\text { Ética líder x Ética líder } \\
\text { (av.seguidor) }\end{array}$ & & & & & , 00 & ,02 \\
\hline $\mathbf{R}^{2}$ & 0,01 & & 0,08 ** & & $0,34 * * *$ & \\
\hline $\mathbf{R}^{2}$ aj. & $-0,01$ & & $0,04 * *$ & & $0,30^{* * *}$ & \\
\hline$\Delta \mathbf{R}^{2}$ & 0,01 & & $0,07 * *$ & & $0,26 * * *$ & \\
\hline
\end{tabular}

Nota: $\mathrm{N}=161$;

$* * \mathrm{p}<0,01 * * * \mathrm{p}<0,001$

Tabela 11: Regressão preditores LMX - SOA 


\section{6. \\ Discussão}

O presente trabalho teve como objetivo examinar a influência da liderança ética no relacionamento de líderes e seguidores e possíveis consequências para o desempenho individual, em diferentes dimensões. A amostra estudada envolveu funcionários, vendedores e gerentes de lojas de uma empresa multinacional de Telecomunicações, com atuação consideravelmente competitiva no mercado brasileiro. A relevância da liderança como fator competitivo neste contexto envolve o desafio de gerenciar pessoas, indicadores, valores e metas (PFEFFER, 1998).

A ética parece ter relevância considerável no ambiente de trabalho, principalmente quando atribuída às pessoas com cargos de gestão (SIU e LAM, 2009). Este fato se deve à responsabilidade que gestores possuem de estabelecer padrões de comportamento através da disciplina e da liderança pelo exemplo (TREVIÑO e NELSON, 2004;BROWN e TREVIÑO, 2006). Outros, sim, um líder considerado ético favorece o relacionamento com seus liderados, o que por sua vez, pode influenciar nos resultados individuais e organizacionais (RUIZ, RUIZe MARTÍNEZ, 2011).

Na amostra considerada, essa afirmação é corroborada uma vez que a liderança ética influencia positivamente o relacionamento entre o líder e sua equipe. Ou seja, quanto mais ético o líder é considerado por seus liderados, melhor é a qualidade da relação estabelecida entre eles. Na amostra investigada, esta constatação é confirmada com alta magnitude pela hipótese H1a onde a liderança ética foi capaz de explicar em 58\% a boa qualidade do relacionamento entre líder e seus seguidores, o que indica sua grande relevância na gestão de pessoas envolvida neste estudo. Esse resultado parece corroborar a teoria desenvolvida acerca da liderança ética, que afirma que o comportamento do líder ético é baseado na equidade e em ações consideradas corretas que beneficiam o grupo liderado e não uma pessoa isoladamente (SCHULMAN, 2002). Dessa 
forma, a honestidade e cuidado com as pessoas fazem com que a gestão desse estilo de líder possa favorecer o bom relacionamento com seus seguidores.

Embora a liderança ética tenha apresentado resultado bastante significativo no impacto do relacionamento entre líderes e seus liderados, as hipóteses relacionadas aos modelos de SOA (H1b) e FIT (H1c)não foram confirmadas. Observou-se que a semelhança na maneira como o líder se autoavalia e é avaliado (SOA) em relação à sua ética não influencia uma melhor qualidade do relacionamento entre líder e sua equipe. Este estudo foi pioneiro em analisar a ética através do SOA, que é um construto amplamente utilizado no que diz respeito ao desempenho do líder na visão dele mesmo e de seus subordinados ou pares (ATWATER et al., 1998; ATWATER et al., 2005).

É possível afirmar também que, para essa amostra, a aproximação entre a ética do subordinado e a ética do líder aparentemente não interfere no relacionamento de maior qualidade (LMX) entre os envolvidos. O FIT tem sido alvo de estudos que investigam a aproximação entre traços da personalidade, valores e atitudes e o impacto na atitude dos funcionários (KRISTOF-BROWN et al., 2005; ZHANGet al., 2012). Porém, no que se refere à ética, os estudos considerando o FIT e o SOA são ainda embrionários.

Embora o FIT e o SOA não acrescentem relevânciaà qualidade do relacionamento estabelecido entre líder e sua equipe, é atribuida extrema importância à percepção dos seguidores sobre a ética de seu líder, o que, isoladamente, evidenciou grande contribuição para o relacionamento estabelecido entre líderes e equipes investigadas.

Em relação aos fatores consequentes de LMX, no que concerne ao desempenho individual avaliado pelo gestor, evidencia-se que, quanto melhor é a qualidade do relacionamento estabelecido entre o líder e seus subordinados (LMX), melhor é o seu desempenho individual, o que corrobora a segunda hipótese deste estudo. Esta constatação amplia a literatura acerca do tema que define LMX como um importante preditor do desempenho individual (BAUER et al., 2006; KLEIN e KIM, 1998; DUNEGAN et al.,1992). A possível explicação para esta associação positiva é que, uma vez que há qualidade no relacionamento, o funcionário é alvo de maior suporte, encorajamento e coaching, o que pode 
significar maior desempenho do mesmo, quando comparado a algum outro que não é alvo dos mesmos investimentos (VECCHIO e GODBEL, 1984; COGLISER et al., 2009). Embora não tenha sido alvo de hipótese proposta neste estudo, o desempenho do subordinado parece ter também um efeito positivo sobre o LMX, o que sugere que subordinados mais bem avaliados por seus líderes foram aqueles que consideram manter uma relação de melhor qualidade com os mesmos.

Ainda que LMX não tenha um efeito positivo na análise do desempenho a partir do atingimento trimestral das metas, a qualidade do relacionamento entre líderes e subordinados apresenta-se como um preditor significativo do comprometimento com a meta (H5). Ou seja, um relacionamento de boa qualidade entre líder e subordinados favorece o comprometimento e determinação em atingir metas estabelecidas, assim, a sugestão para estudos futuros é ampliar a apuração do período de atingimento da meta para seis meses ou um ano de maneira a minimizar qualquer tipo de viés do curto período investigado. $\mathrm{Na}$ organização estudada houve restrição quanto a estes dados, principalmente pelo alto turnover dos vendedores.

Neste estudo não pôde ser observada influência positivada qualidade do relacionamento entre líder e lideradosno comportamento de cidadania organizacional. Essa evidência sugere que a amostra estudada, ainda que influenciada pelo bom relacionamento com seu líder,não apresenta maior incidência do comportamento de ajuda entre equipe, além do que é exigido formalmente pelo contrato de trabalho. É preciso pontuar que obaixo valor do alpha da escala de cidadania organizacional denota baixa confiabilidade de seu uso na amostra investigada, o que significa uma limitação do presente estudo e pode ter se constituído uma barreira para a avaliação mais precisa dessa hipótese.

Contudo, apesar do relacionamento entre líder e subordinados não ser relevante ao comportamento de cidadania, mais uma vez, a liderança ética denota sua importância ao apresentar relação positiva com este tipo decomportamento, o que confirma a terceira hipótese (H3). Ou seja, no grupo estudado, à medida que um líder é considerado ético por seu funcionário, este apresenta maior incidência docomportamento de cidadania, esforçando-se em atitudes que beneficiam a equipe.A explicação para este resultado parece estar relacionada com a característica altruísta desse tipo de líder que, preocupadocom o bem estar de 
outras pessoas, funciona como um modelo para seus liderados (TREVIÑO, BROWN e HARTMAN, 2003; PENNER e FINKELSTEIN, 1998). Mais uma vez, observa-se a importância do líder ser considerado ético por seus seguidores.

\section{1.}

\section{Modelo Alternativo}

A partir dos resultados apresentados, há a proposição de um novo modelo relacionando liderança ética ao LMX e ao comportamento de cidadania organizacional. E, a qualidade do relacionamento entre líder-liderado (LMX) ao desempenho individual e comprometimento com a meta.

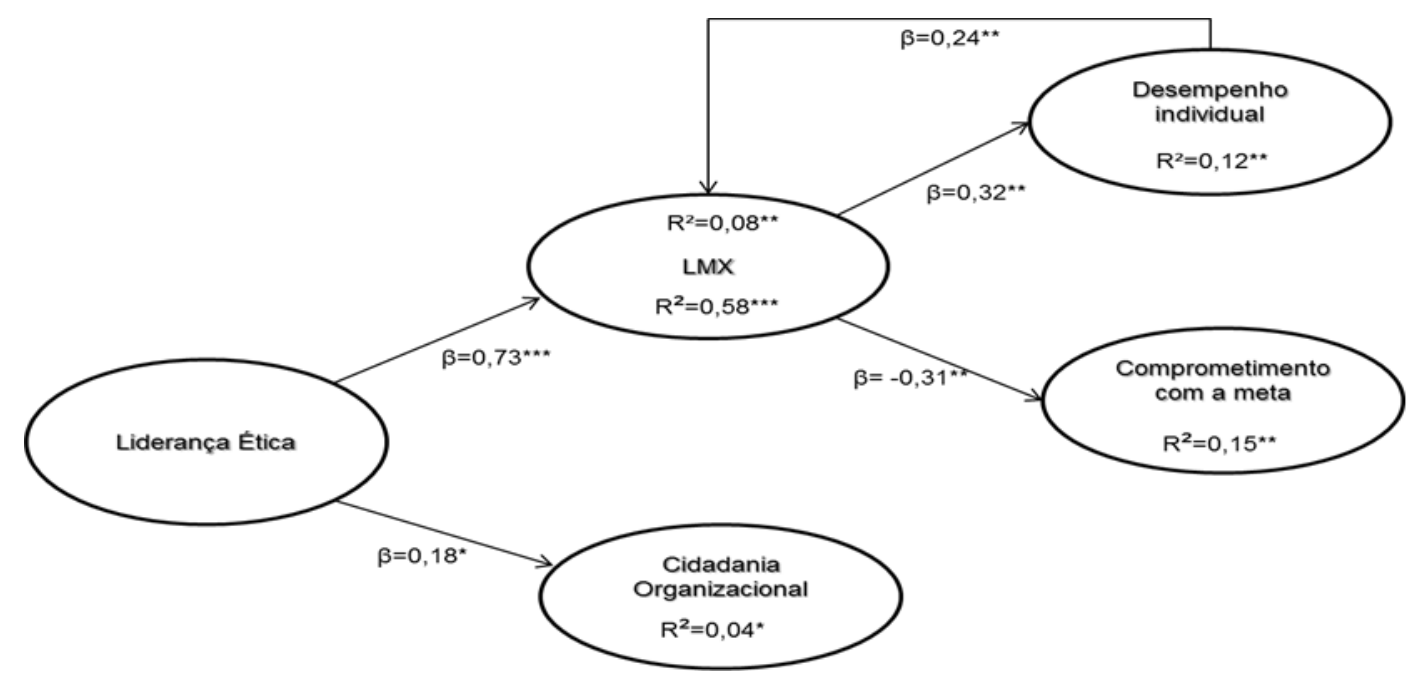

Figura 2: Modelo da pesquisa adaptado 


\section{7. \\ Conclusões e Recomendações}

Este trabalho teve o objetivo de investigar a influência do reconhecimento da ética de um líder sobre o relacionamento estabelecido com seus subordinados e, por sua vez o impacto da qualidade deste relacionamento no desempenho individual, comprometimento com a meta e cidadania organizacional. Os resultados permitem contribuir de maneira significativa com o desenvolvimento da teoria de liderança ética no contexto brasileiro.

\section{1.}

\section{Conclusões e Implicações}

Em um contexto no qual a ética é um assunto debatido internacionalmente, a teoria sobre a liderança ética ainda é recente. Este estudo aponta para evidências empríricas importantes de forma a contribuir com as pesquisas teóricas já existentes.

Ainda que algumas pesquisas tenham investigadoestilos de liderança como antecedentes de ummelhor relacionamento com subordinados, poucos foram os estudos que abordaram a ética no comportamento de líderes como antecedentes deste relacionamento (MASHUD et al., 2010). A influência da liderança ética e os possíveis resultados no comportamento dos liderados carece de estudos empíricos.

Neste sentido, a primeira constatação especialmente relevante é a estreita relação observada entre um líder considerado ético por seus subordinados e oconsequente relacionamento de maior qualidade estabelecido entre eles. Nota-se que além do melhor relacionamento, a liderança ética também é responsável por promover maior incidência do comportamento de cidadania individual entre a equipe. Isto significa que, pessoas gerenciadas por líderes considerados éticos têm maior propensão voluntária a cooperar individualmente umas com as outras.

As evidências empíricas dessa pesquisa corroboram a teoria de que líderes percebidos pelos seguidores com uma motivação menos egoísta e mais altruísta, apresentamcomportamento honesto, consideração por outros e tratamento justo. 
Por consequência, estabelecem um ambiente de trabalho agradável e justo (BROWN et al., 2005; GRAHAM, 1995). Assim, o comportamento de cidadania organizacional é percebido com maior incidência nas equipes que consideram que seus líderes sejam éticos, o que confirma os resultados de pesquisas anteriores nesta temática (MAHSUD et al., 2010; RUIZ et al., 2010).

$\mathrm{Na}$ amostra considerada, o relacionamento de melhor qualidade, fruto de uma liderança considerada ética, é responsável por consequentes importantes: o comprometimento com a meta e o desempenho individual. Isto significa que os funcionários que avaliam como eficaz o relacionamento com seus líderes, possuem boa avaliação de desempenho além de comprometerem-se com as metas de vendas estabelecidas. Uma vez que o número de pesquisas dedicado aos preditores do comprometimento com a meta ainda é escasso e não suficientemente sistematizado (KLEIN et al., 1999), os resultados aqui relatados contribuem para ampliação deste debate.

Embora o comprometimento com a meta assim como o desempenho tenham sido relevantes, vale ressaltar que o efeito positivo no desempenho individualé limitado. Este se apresenta como positivo no que se refere à métrica de desempenho avaliada pelos gestores, não sendo constatado o mesmo efeito na apuração do atingimento trimestral das metas individuais. Algumas explicações para este fato são possíveis: o caráter subjetivo da avaliação de desempenho realizada pelos gestores, o curto período de tempo utilizado na apuração do atingimento das metas, o que pode significar alguma sazonalidade e ainda a não utilização de avaliação comportamental. A utilização de métricas de desempenho que excluam aspectos importantes ao contexto da atividade ou tarefa pode ter impacto no resultado apresentado (KLEIN e KIM, 1998).

Assim, uma sugestão para estudos futuros é a utilização de um período maior de apuração das metas individuais, tal como um semestre ou um ano e a utilização de uma avaliação comportamental que considere aspectos relevantes associados à venda e atendimento ao cliente. Com a utilização de métricas objetivas mais robustas e subjetivas mais adequadas, torna-se possível investigar a relação entre elas de modo a verificar maior fidedignididade a esta medida. Assim, também será possível averiguar o nível de convergência entre as duas métricas, objetiva e subjetiva. 
A partir destas considerações é possível contribuir com o delineamento empírico da teoria acerca da liderança ética, principlamente nos efeitos sobre o comportamento de funcionários que consideram seus gestores, como líderes éticos.

\section{2.}

\section{Implicações gerenciais}

A principal contribuição deste estudo encontra-se na importância de incluir a dimensão ética na compreensão sobre o fenômeno da liderançae um melhor relacionamento líder-seguidor (LMX). Melhorar este relacionamento pode ser eficaz no que significa atingir o objetivo de atrair e obter comportamentos importantes dos seguidores.

Para as organizações, o comportamento de cidadania e o ato de comprometer-se com metas de alto nível de dificuldade podem significar melhor nível de desempenho individual além de possíveis resultados organizacionais superiores.

Desta forma, as implicações são diversas, diretamente associadas à gestão de pessoas e indiretamente aos resultados da organização. Assim, as empresas podem obter vantagem a partir do processo de seleção, treinamento e desenvolvimento de líderes éticos.

Especificamente no que se refere à seleção, a organização pode fazer uso de ferramentas que aprofundem a investigação sobre temas como: integridade do candidato, preocupação com os outros, habilidade de ouvir o que outros têm a dizer, senso de justiça ao se relacionarem com subordinados, padrões de comportamento na condução de situações envolvendoética, etc.

No que se refere ao treinamento, não há a pretensão de transformar padrões éticos já existentes, contudo, fazer deste assunto, um debate possível. A formação dos líderes pode envolver temas como: debate de dilemas éticos e possíveis modelos de atuação, a consideração do sucesso através de seus meios e fins, repreensão de funcionários que violam padrões éticos, debate sobre ética com subordinados, senso de justiça relacionado à equipe etc.

Ainda no que diz respeito às contribuições práticas, além dos processos de seleção, treinamento e desenvolvimento, é necessário que as organizações estabeleçam padrões de ética, conduta e indicadores. Algumas ações possíveis 
neste sentido seriam: comunicação sobre a importância da ética nas ações da organização; reconhecimento, premiação e apoio alíderes considerados éticos de forma a transformá-los em modelos "éticos"; criação de indicadores de fraude e combate com ações repressivas.

\section{3.}

\section{Limitações e sugestões para futuras pesquisas}

Este estudo possui limitações que devem ser consideradas. A primeira delas refere-se ao método investigativo utilizado. A técnica de levantamento de dados permite uma análise de tendências acerca de opiniões, atitudes a partir de uma descrição numérica de uma amostra (CRESWELL, 2003). Assim, através desse método, não é possível explorar significados subjetivos aprofundando opiniões dos participantes acerca do tema estudado. A sugestão para estudos posteriores é a utilização de um método misto de investigação, com a coleta e análise de dados quantitativos e qualitativos, permitindo o aprofundamento das questões acerca do tema.

A segunda limitação se refere à sua aplicação e abrangência, uma vez que a amostra foi selecionada por conveniência. Os resultados aqui encontrados não podem ser generalizados para qualquer população; uma vez que cada organização tem um contexto e características específicas e este estudo é restrito especificamente à uma organização, os resultados não podem ser generalizados. Ademais, uma vez que os participantes pertencem a uma delimitada área de atuação na área comercial, os resultados encontrados também não podem ser generalizados para toda a organização. Para pesquisas futuras, sugere-se ampliar a amostra com a inclusão de empresas com abrangência do negóvio e área de atuação.

Uma consideração importante a ser pontuada refere-se ao viés social relacionado ao tema investigado. Uma vez que os construtos analisados associamse às relações sociais, as respostas podem ser alvo de algum tipo de viés em conformidade ao que se considera socialmente desejável. O momento atual da área comercial estudada denota uma condição sensível relacionada a este tema. Recentemente, foram demitidos funcionários por justa causa após investigação rigorosa de fraude e roubo nas lojas. Para minimizar este problema, foi feito uso 
da escala de desejabilidade social que apresentou correlação positiva com as principais variáveis investigadas. No entanto, o índice de confiabilidade dessa escala foi baixo, menor do que $70 \%$. Dessa maneira, para pesquisas futuras, a sugestão é a revisão dessa escala e possível adaptação com validação prévia.

No que concerne ao modelo de pesquisa proposto, a sugestão para futuras pesquisas é ampliar o escopo do presente estudo investigando novas variáveis como consequentes da liderança ética assim como a inclusão de possíveis antecedentesdo líder considerado ético. Dessa maneira, é possível a delimitação mais específica acerca das pessoas que possivelmente são candidatos a exerceruma liderança mais ética. Ademais, sugere-se o teste de mediação da variável LMX em relação às variáveis futuramente investigadas.

De forma a ampliar o estudo sobre a dimensão moral e ética na liderança, é possível nova pesquisa com ênfasena perspectiva moral internalizada da teoria sobre liderança autêntica, conforme necessidade apontada por Gardner et al. (2011).

Em suma, este trabalho apresenta avanço na ampliação dos estudos acerca da teoria de liderança ética, LMX e desempenho, visto que poucas são as investigações empíricas a respeito dessa recente temática. Além da contribuição empírica ao processo de liderança nas organizações, os resultados apresentados permitem contribuir ainda de maneira mais ampla com o debate acerca dos desafios éticos nagestão política e social. 


\section{8. Referências Bibliográficas}

ACADEMY OF MANAGEMENT. 2013. Annual Meeting of the Academy of Management. Disponível em: <http://aom.org/Events/2013-Annual-Meeting-ofthe-Academy-of-Management.aspx>. Acesso em: 06 de agosto de 2013.

ASGARI, A., SILONG, A., AHMAD, A.,SAMA, B. The Relationship between Transformational Leadership Behaviors, Leader-Member Exchange and Organizational Citizenship Behaviors. European Journal of Social Science, 6,pp.140-151, 2008.

ASHFORTH, B., MAEL, F.Social identity theory and the organization. Academy ofManagement Review,14, pp. 20-39, 1989.

ATWATER, L., YAMMARINO, F. Self-other rating agreement: A review and model. Personnel and Human Resource Management, 15, pp. 121-174, 1997.

ATWATER, L., WANG, M., SMITHER, J., \& Fleenor, J. Are cultural characteristics associated with the relationship between self and others' ratings of leadership? Journal of Applied Psychology, 94, pp. 876-886, 2009.

ATWATER, L., OSTROFF, C., YAMMARINO, F., \& FLEENOR, J. Self-Other Agreement: Does It Really Matter? Personnel Psychology, 51(3), pp. 577-598, 1998.

ATWATER, L., WALDMAN, D., OSTROFF, C., ROBIE, C., \& JOHNSON, K.Self - Other Agreement: Comparing its Relationship with Performance. International Journal of selection and Assessment. 13(1), pp. 25-40, 2005.

AVOLIO, B., GARDNER, W. Authentic leadership development: Getting to the root of positive forms of leadership. The Leadership Quarterly,16, pp. 315-338, 2005.

BABCOCK-ROBERSON, M., STRICKLAND, O. Leadership, Work Engagement and Organizational Citizenship Behaviors. The Journal of Psychology 144(3), pp. 313-326, 2010.

BANDURA, A. Social foundations of thought and action: A social cognitive theory. Englewood Cliffs: Prentice-Hall, 1986.

BANDURA, A., JOURDEN, F. Self-regulatory mechanisms governing the impact of social comparison on complex decision making. Journal of Personality and Social Psychology,60, pp. 941-951, 1991. 
BATAGLIA, P., MORAIS, A.;LEPRE, R. A teoria de Kohlberg sobre o desenvolvimento do raciocínio moral e os instrumentos de avaliação de juízo e competência moral em uso no Brasil. Estudos de Psicologia,15, pp. 25-32, 2010.

BAUER, T., GREEN, S. Development of leader member exchange: A longitudinal test. Academy of Management Journal,39, pp. 1538-1567, 1996.

BAUER, T., ERDOGAN, B., LIDEN, R., WAYNE, S. A longitudinal study of the moderating role of extraversion: Leader-member exchange, performance and turnover during new executive development. Journal of Applied Psychology, 91, pp. 298-310, 2006.

BARNES, R., LEA, T. Citizenship in practice. British Journal of Social Psychology, 43, pp. 187-206, 2004.

BLACK, K. Business Statistics: Contemporary Decision Making.John Wiley \& Sons, 2010.

BROWN, M., TREVIÑO, L. Ethical leadership: A review and future directions. The Leadership Quarterly,17, pp. 595-616, 2006.

BROWN, M., TREVIÑO, L., HARRISON, D. Ethical leadership: A social learning perspective for construct development and testing. Organizational Behavior and Human Decision Processes,97, pp. 117-134, 2005.

BRUTUS, S., Fleenor, J., \& Tisak, J. Exploring the Link Between Rating Congruence and Managerial Effectiveness. Canadian Journal of administrativejournal, 16 (04), pp. 308-322, 1999.

CROWNE, D., MARLOWE, D. A new scale of social desirability independent of psychopathology. Journal of Consulting Psychology, 24, pp. 349-354, 1960.

CAVAZOTTE, F.,VILAS BOAS, O., MORENO, V. Authentic Leadership and Employee Performance: Effects trough Justice and Creativity. In: Annual Meeting of the Academy of Management, 2012.

CIULLA, J. Ethics: the heart of Leadership.United States of America: Greenwood Pub Group, 2004.

COGLISER, C., SCHIRIESHEIM, C., SCANDURA, T., GARDNER,W.Balance in leader and follower perceptions of leader-member exchange: Relationships with performance and work attitudes. The Leadership Quarterly, 20, pp.452-465, 2009.

COOPER, D., SCHINDLER, P. Métodos de Pesquisa em Administração. Porto Alegre: Editora Bookman, 2003.

CRESWELL, J.Research design: Qualitative, quantitative, and mixed methods approaches. Thousand Oaks, CA: Sage, 2003. 
DAY, D., ANTONAKIS, J. The nature of leadershipdevelopment.Los Angeles: Sage, 2011.

DANSEREAU, F., GRAEN, G., HAGA, W.A vertical dyad linkage approach to leadership within formal organizations: a longitudinal investigation of the role making process. Organizational Behavior and Human Performance, 13, pp. 46-78, 1975.

DAVEL, E., MACHADO, H.Dinâmica entre Liderança e Identificação : Sobre a Influência Consentida nas Organizações Contemporâneas. Revista de Administração contemporânea, 7, pp. 107-126, 2001.

DE HOOGH, A., DEN HARTOG, D. Ethical and despotic leadership, relationships with leader's social responsibility, top management team effectiveness and subordinates' optimism: A multi-method study. Leadership Quarterly, 19(3), pp. 297-311, 2008.

DE MASI, D. O ócio criativo. Rio de Janeiro:Sextante, 2000.

DIENESCH, R., LIDEN, R. Leader-Member Exchange Model of Leadership : A Critique and Further Development. The Academy of Management,11, pp. 618634, 1986.

DRUCKER, P. (1909). O melhor de Peter Drucker; tradução de Maria Lúcia L. Rosa. São Paulo: Nobel, 2001.

DUNEGAN, K., DUCHON, D., UHL-BIEN, M. Examining the link between leader member exchange and subordinate performance: The role of task analyzability and variety as moderators. Journal of Management, 18, pp. 59-76, 1992.

DUARTE, N., GOODSON, J.,KLICH, N. Effects of dyadic quality and duration on performance appraisal. Academy of Management Journal, 37, pp. 499-521, 1994.

ÉBOLI, C., CAVAZOTTE, F., LUCENA, J.O Impacto da Autenticidade do Líder e do Foco em Resultados sobre o Desempenho no Trabalho: Um Estudo com Funcionários de um Banco Privado Brasileiro.In: Anais do Encontro Nacional da Associação Nacional de Pós-Graduação e Pesquisa em Administração, Rio de Janeiro, RJ, Brasil,2012.

EDWARDS, J., CABLE, D. The value of value congruence. Journal of Applied Psychology, 94, pp. 654-677, 2009.

EDWARDS, J., PARRY, M. On the use ofpolynomial regression equations as an alternativeto difference scores in organizational research.

Academy of Management Journal,36, pp.1577-1613, 1993. 
EDWARDS, J.The study of congruence in organizational behavior research: Critique and a proposed alternative. Organizational Behavior and Human Processes, 58, pp. 51-100, 1994.

EMMERIK, I., JAWAHAR, I., STONE, T. Associations among altruism, burnout dimensions, and organizational citizenship behavior.Work and Stress, 19, pp. 93$100,2005$.

ERDOGAN, B., KRAIMER, M., LIDEN, R. Work Value Congruence and Intrinsic Career Success: the Compensatory Roles of Leader-Member Exchange and Perceived Organizational Support. Personnel Psychology,57, pp. 305-332, 2004.

FLEENOR, J., MCCAULEY, C.,BRUTUS, S. Self-other rating agreement and leader effectiveness. Leadership Quarterly, 7, pp. 487-506, 1996.

FLEENOR, J., SMITHER, J., ATWATER, L., BRADDY, P., STURM, R.Selfother rating agreement in leadership: A review. The Leadership Quarterly, 21(6), pp. 1005-1034, 2010.

GARDNER, W., COGLISER, C., DAVIS, K., DICKENS, M. Authentic leadership: A review of the literature and research agenda. The Leadership Quartely, 22, pp. 1120-1145, 2011.

GEORGE, B., SIMS, P., MCLEAN, A., MAYER, D. Discovering Your Authentic Leadership. Harvard Business Review, 85, pp.129-138, 2007.

GRAEN, G., UHL-BIEN, M. Relationship-based approach to leadership: Development of leader-member exchange (LMX) theory of leadership over 25 years: Applying a multi-level multi-domain perspective. The Leadership Quarterly,6, pp. 219-247, 1995.

GRAHAM, J. Leadership, moral developmentand citizenship behavior.Business Ethics Quarterly,5, pp. 43-55, 1995.

HENEMAN, R., GREENBERGER, D., ANONYO, C. Attributions and exchanges: The effects of interpersonal factors on the diagnosis of employee performance. Academy of Management Journal,32, pp. 466-476, 1989.

HERSEY, P., BLANCHARD, K. Psicologia para administradores: A teoria e as técnicas da liderança situacional. São Paulo: EPU, 1986.

HOLLENBECK, J., WILLIAMS, C., KLEIN, H. An empirical investigation of the antecedents of commitment to difficult goals. Journal of Applied Psychology, 74, pp. 18-23, 1989.

HUGHES, R., GINNETT, R., CURPHY, G. Leadership:enhancing the lessons of experience. Boston: McGraw-Hill, 2005. 
ISHAK, N., ALAM, S. The Effects of Leader-Member Exchange on Organizational Justice and Organizational Citizenship Behavior: Empirical Study. European Journal of Social Sciences,8, pp.324-334,2009.

JACKSON, E., JOHNSON, R. When opposites do (and do not) attract: Interplay of leader and follower self-identities and its consequences for leader-member exchange. The Leadership Quarterly, 23(3), pp. 488-501, 2012.

KAMDAR, D., VAN DYNE, L. The joint effects of personality and workplace social exchange relationships in predicting task performance and citizenship performance. Journal of Applied Psychology, 92, pp.1286-1298, 2007.

KEMELGOR, B. Job satisfaction as mediated by the value congruity of supervisors and their subordinates. Journal of Occupational Behavior, 3, pp. 147-160, 1982.

KLEIN, H., KIM, J. A field study of the influence of situational constraints, leader-member exchange, and goal commitment on performance. Academy of Management Journal, 41, pp. 88-95, 1998.

KLEIN, H., WESSON, M., HOLLENBECK, J., ALGE, B. Goal commitment and the goal-setting process: Conceptual clarification and empirical synthesis. Journal of Applied Psychology, 84, pp. 885-896, 1999.

KOCIATKJEWICZ, J., KOSTERA, M. The Good Manager: An Archetypical Quest for Morally Sustainable Leadership. Organization Studies,33, pp. 861$878,2012$.

KOHLBERG, L. Development of moral character and moral ideology. Review of child development research. New York: Russell-Sage Foundation, 1964.

KONOVSKY, M., ORGAN, D. Dispositional and contextual determinants of organizational citizenship behavior. Journal of Organizational Behavior,17, pp.253-266, 1996.

KOTTER, J. What leaders really do. Harvard Business Review, 68, pp. 1-12, 1990.

KRISTOF-BROWN, A., ZIMMERMAN, R., JOHNSON, E. Consequences of Individuals' Fit At Work: a Meta-Analysis of Person-Job, Person-Organization, Person-Group, and Person-Supervisor Fit. Personnel Psychology, 58, pp. 281342, 2005.

LAGRACE, R. Leader-member exchange: Antecedents and consequences of the cadre and hired hand. Journal of Personal Selling and Sales Management, 10, pp.11-19, 1990.

LE BLANC, P., GONZÁLEZ-ROMÁ, V. A team level investigation of the relationship between Leader-Member Exchange (LMX) differentiation, and 
commitment and performance. The Leadership Quarterly, 23, pp.534-544, 2012.

LEE, Y., STETTLER, A., ANTONAKIS, J.Incremental validity and indirect effect of ethical development on work performance. Personality and Individual Differences,50, pp. 1110-1115, 2011.

LEPINE, J., EREZ, A., JOHNSON, D.The nature and dimensionality of organizational citizenship behavior: A critical review and meta-analysis. Journal of Applied Psychology, 87, pp. 52-65,2002.

LIDEN, R.,WAYNE, S., STILWELL, D. A longitudinal study on the early development of leader-member exchanges. The Journal of Applied Psychology, 78, pp. 662-674, 1993.

LOCKE, E., LATHAM,G.A Theory of GoalSetting and Task Performance. EnglewoodCliffs:Prentice Hall, 1990.

LOCKE, E., LATHAM, G., EREZ, M. The determinants of goal commitment. Academy of Management Review, 13, pp. 23-39, 1988.

LUTHANS, F., AVOLIO, B., AVEY, J., NORMAN, S. Positive Psychological Capital: Measurement and Relationship With Performance and Satisfaction. Personnel Psychology, 60(3),pp. 541-572, 2007.

MARCONDES, D. Textos Básicos de ética: de Platão a Foucault. Rio de. Janeiro: Jorge Zahar, 2007.

MARKHAM, S., YAMMARINO, F., MURRY, W., PALANSKI, M. Leader member exchange, shared values, and performance: Agreement and levels of analysis do matter. The Leadership Quarterly,21, pp. 469-480, 2010.

MASHUD, R., YUKL, G., PRUSSIA, G. Leader empathy, ethical leadership, and relations-oriented behaviors as antecedents of leader-member exchange quality. Journal of Managerial Psychology, 25, pp. 561-577, 2010.

MAY, D., HODGES, T., CHAN, A., AVOLIO, B. Developing the moral component of authentic leadership. Organizational Dynamics, 32, pp. 247-260, 2003.

METCALF, L., BENN, S. Leadership for Sustainability: An Evolution of Leadership Ability. Journal of Business Ethics, 112, pp. 369-384, 2012.

MONTEIRO, J., ESPÍRITO SANTO, F.,BONACINA, F. Valores, ética e julgamento moral: Um estudo exploratório em empresas familiares. Psicologia: Reflexão e Crítica, 18, pp. 237-246, 2005.

MOTOWIDLO, S., BORMAN, W., SCHMIT, M. A theory of individual differences in task and contextual performance. Human Performance, 10, pp.7183, 1997. 
NORTHOUSE, P. Leadership: Theory and Practice. 5a. ed. Thousand Oaks, California: Sage Publications, 2010.

OAKES, P.,TURNER, J. Distinctiveness and the salience of social category membership: is there an automatic perceptual bias toward novelty? European Journalof Social Psychology, 16, pp. 325-344, 1986.

ORGAN, D.Organizational citizenship behavior: The good soldier syndrome. Lexington: Lexington Books, 1988.

ORGAN, D., RYAN, K. A Meta-Analytical Review of Attitudinal and Dispositional Predictors of Organizational Citizenship Behavior. Personnel Psychology, 48, pp.775-802, 1995.

OSTROFF, C., SHIN, Y., KINICKI, A. Multiple perspectives of congruence: Relationships between value congruence and employee attitudes. Journal of Organizational Behavior, 26, pp. 591-623,2005.

OSTROFF, C., ATWATER, L., FEINBERG, B. Understanding self-other agreement: A look at rater and ratee characteristics, context, and outcomes. Personnel Psychology, 57, pp. 333-375, 2004.

PATERSON, M., WEST, M., LAWTHOM, R., NICKELL, S. Impact of people management practices on business performance. London: institute of personnel and development, 1997.

PENNER, L., FINKELSTEIN, M. Dispositional and structural determinants of volunteerism. Journal of Personality and Social Psychology, 74(2), pp. 525537, 1998.

PENNER, L., MIDILI, A., KEGELMEYER, J. Beyond job attitudes: A personality and social psychology perspective on the causes of organizational citizenship behavior. Human Performance, 10, pp. 111-131, 1997.

PETERSON, D., HICKS, M.Development First: Strategies for Self Development.Personnel Decisions, 1995.

PFEFFER, J. The human equation: building profits by putting people first. Boston: Harvard Business School Press, 1998.

PICCOLO, R., COLQUIT, J. Transformational leadership and job behaviors: the mediating role of core job characteristics. Academy of Management Journal, 49, pp. 327-40, 2006.

PICOOLO, R., GREENBAUM, R., DEN HARTOG, D., FOLGER, R. The relationship between ethical leadership and core job characteristics. Journal of Organizational Behavior, 31, pp. 259-278, 2010. 
PODSAKOFF, P., MACKENZIE, S. Impact of organizational citizenship behavior on organizational performance: A review and suggestions for future research.Human Performance, 10(2), pp. 133-151,1997.

PODSAKOFF, P., MACKENZIE, S., MOORMAN, H., FETTER, R. Leader Behaviors and their effects on followers trust in leader, satisfaction and citizenship behaviors. Leadership Quarterly, 1(2), pp. 107-142,1990.

PODSAKOFF, P., MACKENZIE, S., PAINE, J., BACHRACH, D. Organizational citizenship behaviors: A critical review of the theoretical and empirical literature and suggestions for future research. Journal of Management, 26, pp.513-563, 2000.

PRICE, T. The ethics of authentic transformational leadership. The leadership Quartely, 14, pp. 67-81, 2003.

REGO, A. Climas éticos e comportamentos de cidadania organizacional. Revista de Administração de Empresas.42 (1), pp. 50-63, 2002.

RHODE, D. Moral leadership: The theory and practice of power, judgment, and policy. San Francisco: Jossey-Bass, 2006.

ROST, J. Leadership for the twenty-first century. New York: Praeger, 1991.

RUIZ, C., RUIZ P., MARTINEZ, R. Improving the "Leader - Follower" Relationship : Top Manager or Supervisor? The Ethical Leadership Trickle-Down Effect on Follower Job Response. Journal of Business Ethics, pp. 587-608, 2011.

SANT'ANNA, A. Competências de liderança ou gerenciais? Uma análise sob a perspectiva foucaultiana de poder. In: NELSON, R., SANT'ANNA, A. (Org.). Liderança: entre a tradição, a modernidade e a pós-modernidade. $1^{\mathrm{a}}$ ed. Rio de Janeiro: Campus-Elsevier, 1, pp. 185-218, 2010.

SCHULMAN, M. How we become moral: The sources of moral motivation.InSynder, C., Lopez, S. (Eds.). Handbook of positive psychology, pp. 499-514, Oxford: Oxford University Press, 2002.

SIU, N, LAM, K. A Comparative Study of Ethical Perceptions of Managers and Non-Managers. Journal of Business Ethics, 88(1), 167-183, 2009.

SMITH, C., ORGAN, D., NEAR, J. Organizational citizenship behavior: it's nature, and antecedents. Journal of Applied Psychology, 68, pp. 653-663, 1983.

STEINER, D. Value perceptions in leader-member exchange. Journal of Social Psychology, 128, pp. 611-618, 1988.

STONER, J., FREEMAN, R. Administração.5a ed. Rio de Janeiro: Ed. PrenticeHall do Brasil, 1985. 
STRAHAN, R., GERBASI, K. Short Homogeneous Versions of the MarloweCrowne Social Desirability Scales. Journal of Clinical Psychology, 28, pp. 191193, 1972.

TREVIÑO, L., BROWN, M., HARTMAN, L. A Qualitative Investigation of Perceived Executive Ethical Leadership: Perceptions from Inside and Outside the Executive Suite. Human Relations, 56, pp. 5-37, 2003.

TREVIÑO, L., NELSON, K.Managing Business Ethics.Straight Talk About How to do it Right. New York : John Wiley \& Sons, 2004.

TSUI, A., O'REILLY, C. Beyond simple demographic effects: Theimportance of relational demography in superior-subordinate dyads. Academy of Management Journal, 31, pp. 402-423, 1989.

TUMASJAN, A., STROBEL, M., WELPE, I. Ethical leadership evaluations after moral transgression: Social distance makes the difference. Journal of Business Ethics, 99, pp. 609-622, 2011.

WALUMBWA, F., AVOLIO, B., GARDNER, W., WERNSING, T., PETERSON, S. Authentic Leadership: Development and Validation of a TheoryBased Measure. Journal of Management,34, pp. 89-126, 2008.

WALUMBWA, F., MAYER, D., WANG, P., WANG, H., WORKMAN, K., CHRISTENSEN, A. Linking ethical leadership to employee performance: The roles of leader-member exchange, self-efficacy, and organizational identification. Organizational. Behavior and Human Decision Processes, 115, pp. 204-213, 2011.

WILLIAMS, L.,ANDERSON, S. Job satisfaction and organizational commitment as predictors of organizational citizenship and in-role behaviors. Journal of Management, 17, pp. 601-617, 1991.

WOFFORD, J., GOODWIN V., PREMACK, S. Meta analysis of the antecedents of personal goal level and of the antecedents and consequences of goal commitment. Journal of Management, 18, pp. 595-615, 1992.

YAMMARINO, F., ATWATER, L. Understanding self-perception accuracy: Implications for human resource management. Human Resource Management, 32, pp. 231-247, 1993.

YUKL, G. How leaders influence organizational effectiveness. The Leadership Quarterly,19, pp. 708-722, 2008.

YUKL, G. Leadership in organizations. 7a ed. Englewood Cliffs: Prentice Hall, 2010.

VAN KNIPPENBERG, D., VAN KNIPPENBERG, B., DE CREMER, D., HOGG, M.Leadership, self, and identity: a review and research agenda. The Leadership Quarterly, 15, pp. 825-856, 2004. 
VECCHIO, R.; GOBDEL, B. The vertical dyad linkage model of leadership: Problems and prospects. Organizational Behavior and Human Performance,34, pp. 5-20, 1984.

VergarA, S. Projetos e Relatórios de Pesquisa e Administração. São Paulo: Atlas, 1997.

ZHANG, Z., WANG, M., SHI, J. Leader-follower congruence in proactive personality and work outcomes: The mediating role of leader-member exchange. Academy of Management Journal, 55, pp. 111-130, 2012.

ZHOU, X., SCHRIESHEIM, C. Supervisor-subordinate agreement on leadermember exchange (LMX) quality: Review and testable propositions. The Leadership Quarterly, 20, pp. 920-932, 2009. 


\section{9.}

\section{APÊNDICE}

Neste capítulo serão apresentados todos os instrumentos utilizados na pesquisa. $\mathrm{O}$ apêndice $\mathrm{A}$ refere-se ao questionário dos funcionários e o apêndice $\mathrm{B}$ ao questionário dos líderes.

\section{1.}

Apêndice A 
Caro participante,

Esta é uma pesquisa acadêmica que tem por objetivo estudar as impressões das pessoas em relação ao trabalho, é muito importante que você preencha o questionário expressando a sua real percepção.

Todas as informações contidassão de caráter sigiloso, não sendo disponibilizadas para qualquer pessoa de sua empresa.

Parabéns! Sua colaboração permitirá o aprofundamento do conhecimento sobre a área de comportamento organizacional.

Insira aquiseu código para iniciar sua participação:

As perguntas a seguir referem-se à sua rotina no trabalho. Para cada item, escolha a alternativa que julga ser mais adequada lembrando que não existe uma resposta certa.

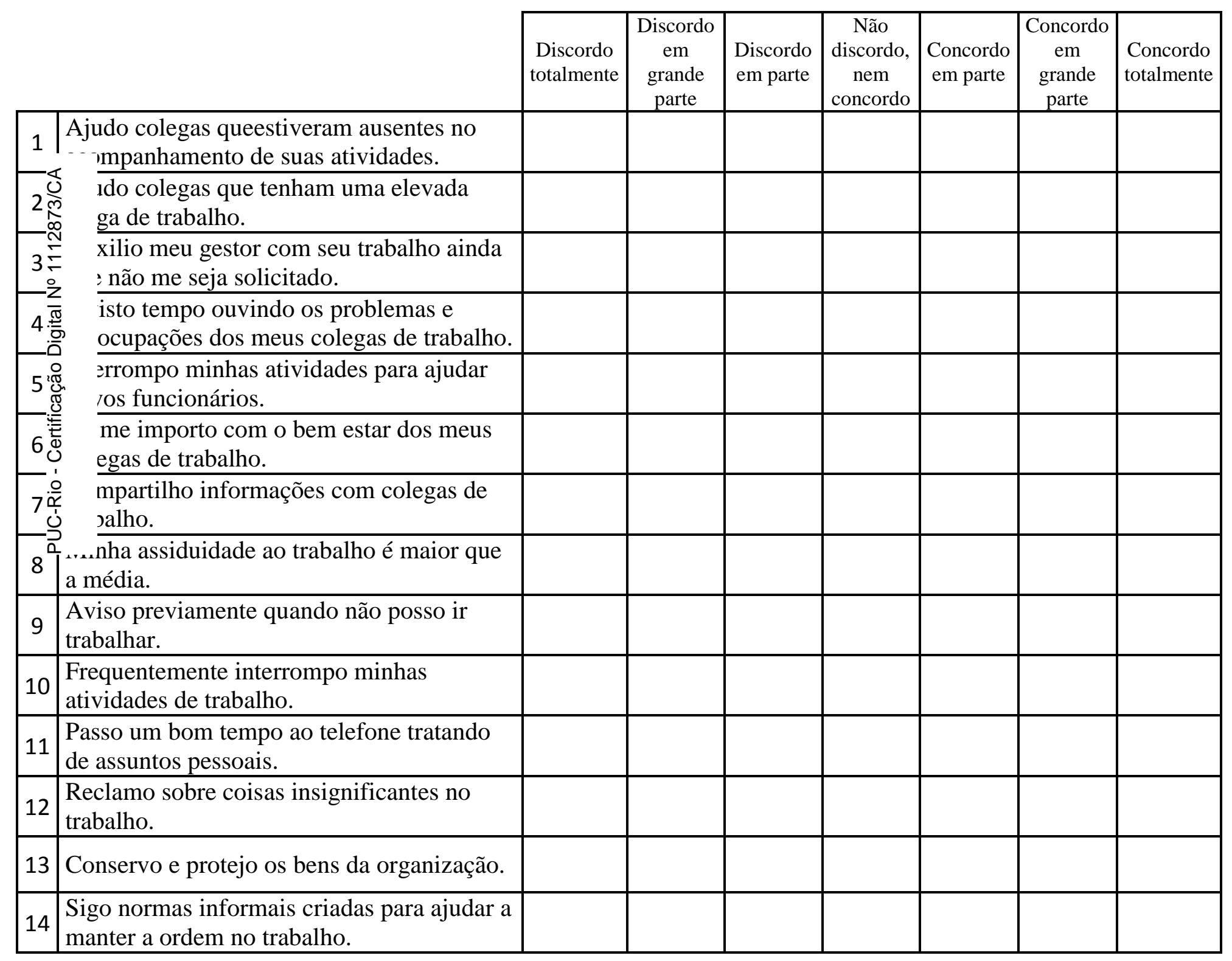


As perguntas a seguir referem-se a como você se sente em relação às suas metas no trabalho.

\begin{tabular}{|c|c|c|c|c|c|c|c|c|c|c|}
\hline & & & \multirow{2}{*}{\multicolumn{2}{|c|}{$\begin{array}{l}\text { Discordo } \\
\text { totalmente }\end{array}$}} & & & \multirow{2}{*}{\multicolumn{2}{|c|}{$\begin{array}{c}\text { Não } \\
\text { discordo, } \\
\text { nem } \\
\text { concordo }\end{array}$}} & \multirow{3}{*}{$\begin{array}{c}\text { Concordo } \\
\text { em parte }\end{array}$} & \multirow{3}{*}{$\begin{array}{c}\text { Concordo } \\
\text { totalmente }\end{array}$} \\
\hline & & & & & $\begin{array}{l}\text { Discc } \\
\text { em } p\end{array}$ & ordo & & & & \\
\hline 15 & \multicolumn{2}{|c|}{ É difícil levar algumas de minhas metas a sério. } & & & & & & & & \\
\hline 16 & \multicolumn{2}{|c|}{$\begin{array}{l}\text { Não é realista esperar que eu vou alcançar todas as } \\
\text { minhas metas. }\end{array}$} & & & & & & & & \\
\hline 17 & \multicolumn{2}{|c|}{$\begin{array}{l}\text { É bem provável que minhas metas tenham que ser } \\
\text { revistas dependendo de como as coisas forem. }\end{array}$} & & & & & & & & \\
\hline 18 & \multicolumn{2}{|c|}{$\begin{array}{l}\text { Sinceramente, não me importo se vou alcançar ou não } \\
\text { minhas metas. }\end{array}$} & & & & & & & & \\
\hline 19 & \multicolumn{2}{|c|}{$\begin{array}{l}\text { Sou bastante comprometido pra tentar alcançar } \\
\text { minhas metas. }\end{array}$} & & & & & & & & \\
\hline 20 & \multicolumn{2}{|c|}{$\begin{array}{l}\text { Por muito pouco não desisto de alcançar minhas } \\
\text { metas. }\end{array}$} & & & & & & & & \\
\hline \multirow{3}{*}{ 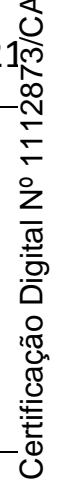 } & \multicolumn{2}{|c|}{$\begin{array}{l}\text { 次o que minhas metas são bem razoáveis para se } \\
\text { ltar alcançar. }\end{array}$} & & & & & & & & \\
\hline & \multicolumn{10}{|c|}{$\begin{array}{l}\text { uestões a seguir referem-se à você. Para cada item, escolha a alternativa que julga ser mais adequada } \\
\text { Irando que não existe uma resposta certa. }\end{array}$} \\
\hline & 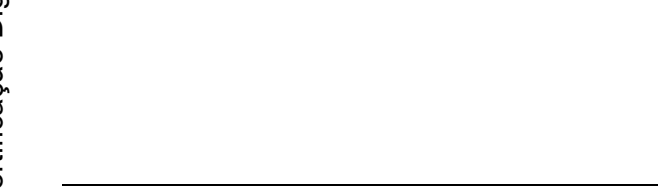 & $\begin{array}{l}\text { Discordo } \\
\text { totalmente }\end{array}$ & $\begin{array}{c}\text { Discordo } \\
\text { em } \\
\text { grande } \\
\text { parte }\end{array}$ & $\begin{array}{l}\text { Discc } \\
\text { em p }\end{array}$ & \begin{tabular}{l|l} 
cordo \\
parte \\
\end{tabular} & $\begin{array}{r}\text { Nã } \\
\text { discor } \\
\text { nem } \\
\text { conco }\end{array}$ & \begin{tabular}{l|}
$\mathrm{do}$ \\
$\mathrm{do}$ \\
$\mathrm{n}$ \\
$\mathrm{rdo}$
\end{tabular} & \begin{tabular}{c|} 
Concordo \\
em parte
\end{tabular} & $\begin{array}{c}\text { Concordo } \\
\text { em } \\
\text { grande } \\
\text { parte }\end{array}$ & $\begin{array}{l}\text { Concordo } \\
\text { totalmente }\end{array}$ \\
\hline 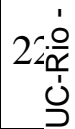 & $\begin{array}{l}\text { npre tomo decisões difíceis com ba } \\
\text { altos padrões de conduta ética. }\end{array}$ & & & & & & & & & \\
\hline 23 & $\begin{array}{l}\text { Defino sucesso não apenas pelos } \\
\text { resultados mas também pela maneira } \\
\text { como são alcançados. }\end{array}$ & & & & & & & & & \\
\hline 24 & Escuto o que os outros tem a dizer. & & & & & & & & & \\
\hline 25 & $\begin{array}{l}\text { Recrimino funcionários que violam } \\
\text { padrões éticos. }\end{array}$ & & & & & & & & & \\
\hline 26 & Tomo decisões justas e equilibradas. & & & & & & & & & \\
\hline 27 & $\begin{array}{l}\text { Sempre faço o que me comprometo a } \\
\text { fazer. }\end{array}$ & & & & & & & & & \\
\hline
\end{tabular}




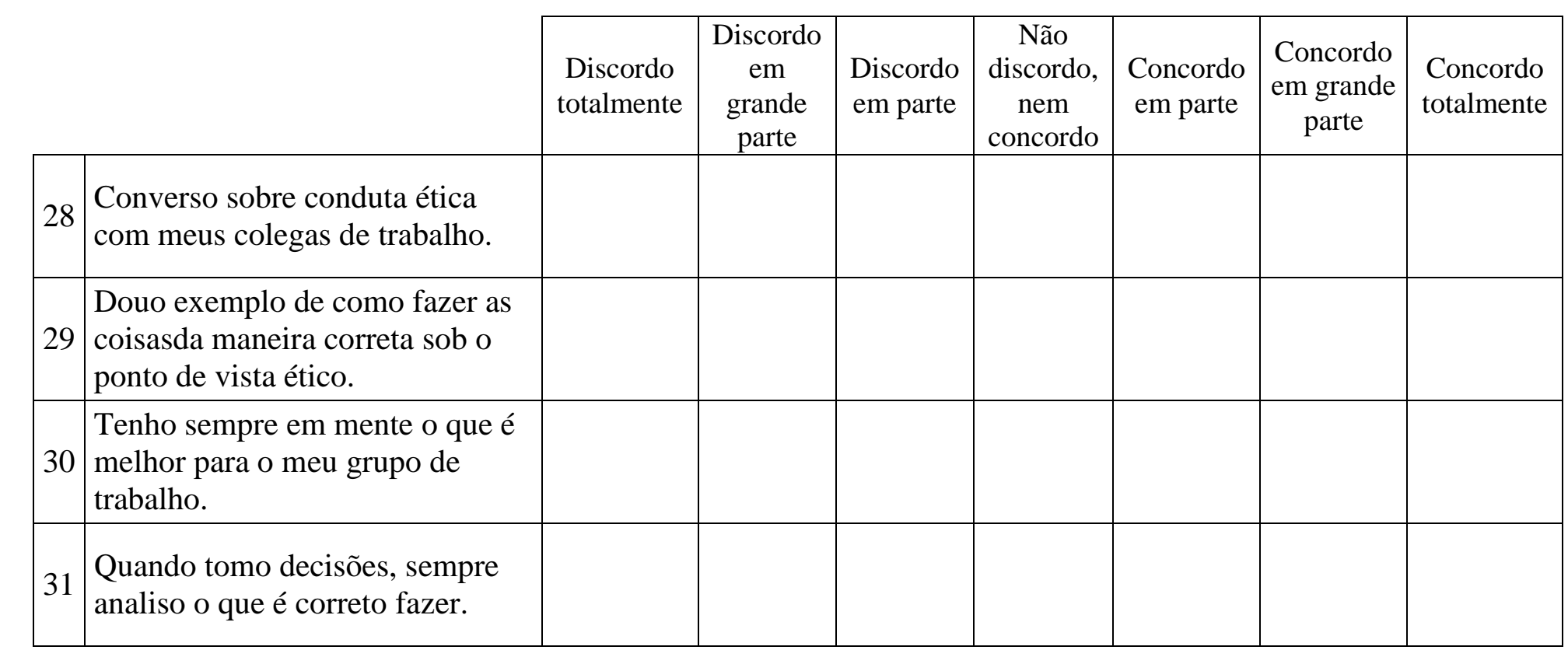

As questões àseguir referem-se à você. Para cada questão, escolha a alternativa que considera mais adomuada, lembrando que não existe uma resposta certa e que nenhuma pessoa de sua empresa terá acesso ¿্র respostas.

\begin{tabular}{|c|c|}
\hline $\begin{array}{c}\text { Concordo } \\
\text { em grande } \\
\text { parte }\end{array}$ & $\begin{array}{l}\text { Concordo } \\
\text { totalmente }\end{array}$ \\
\hline \multicolumn{2}{|c|}{$\begin{array}{l}\text { Eu nunca atravessoa rua sem olhar } \\
\text { para os dois lados. }\end{array}$} \\
\hline \multicolumn{2}{|c|}{ Eu nunca tive inveja de ninguém. } \\
\hline \multicolumn{2}{|c|}{ Não tenho vergonha de nada. } \\
\hline & \\
\hline & \\
\hline & \\
\hline & \\
\hline & \\
\hline & \\
\hline & \\
\hline
\end{tabular}




\section{As questões abaixo dizem respeito a sua relação com seu superior imediato.}

\section{Lembre-se que suas respostas são de caráter sigiloso, ninguém na sua empresa terá conhecimento das} mesmas.

42-Você sabe como está em relação ao seu gestor e geralmente sabe o quão satisfeito ele(a) está com o que você faz?

O Raramente

O Ocasionalmente

O Às vezes

Com muita freqüência

Com bastante frequiência

43-O seu gestor compreende os seus problemas e necessidades no trabalho?

Nem um pouco

O Pouco

Na quantidade justa

O Razoável

O Muito

$\circlearrowleft$ té que ponto o seu gestor reconhece seu potencial?

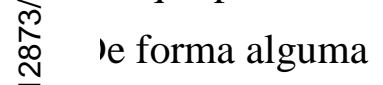

$\mp$ Im pouco

’ Ioderadamente

. maior parte das vezes

'ompletamente

(7) Idependentemente da autoridade formal que ele apresenta em sua posição, quais são as chances dele(a) ar seu poder para ajudá-lo a resolver problemas em seu trabalho?

Tenhuma

$\stackrel{\frac{0}{\sim}}{s}$ ouca

Ioderada

O Alta

O Muito alta

46-Novamente, independentemente de quanta autoridade formal que seu gestor tenha, quais são as chances dele "socorrê-lo", assumindo o ônus de problemas?

O Nenhuma

O Pouca

O Moderada

O Alta

O Muito alta 
47-Eu tenho tanta confiança no meu chefe, que poderia defender e justificar sua decisão mesmo se ele não estiver presente.

O Discordo totalmente

O Discordo

O Neutro

O Concordo

O Concordo totalmente

48-Como você poderia caracterizar sua relação de trabalho com seu chefe?

O Extremamente ineficaz

P Pior que a média

O Média

O Melhor que a média

O Extremamente eficaz

Os itens à seguir referem-se ao estilo do(a) seu(sua) líder, de acordo com sua percepção.

Por favor, avalie com que frequência cada afirmação está relacionada ao estilo de liderança dele ou dela de maneira a completar a seguinte frase:Meu (minha) líder...

\begin{tabular}{|c|c|c|c|c|c|c|c|c|}
\hline 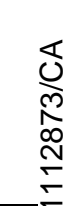 & & $\begin{array}{l}\text { Discordo } \\
\text { totalmente }\end{array}$ & $\begin{array}{l}\text { Discordo } \\
\text { em } \\
\text { grande } \\
\text { parte }\end{array}$ & $\begin{array}{l}\text { Discordo } \\
\text { em parte }\end{array}$ & $\begin{array}{c}\text { Não } \\
\text { discordo, } \\
\text { nem } \\
\text { concordo }\end{array}$ & $\begin{array}{l}\text { Concordo } \\
\text { em parte }\end{array}$ & $\begin{array}{l}\text { Concordo } \\
\text { em } \\
\text { grande } \\
\text { parte }\end{array}$ & $\begin{array}{l}\text { Concordo } \\
\text { totalmente }\end{array}$ \\
\hline $4 \stackrel{\frac{1}{2}}{2}$ & $\begin{array}{l}\text { nduz sua vida pessoal de } \\
\text { neira ética. }\end{array}$ & & & & & & & \\
\hline 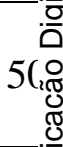 & $\begin{array}{l}\text { fine sucesso não apenas pelos } \\
\text { ultados mas também pela } \\
\text { neira como são alcançados. }\end{array}$ & & & & & & & \\
\hline 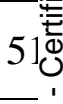 & $\begin{array}{l}\text { zuta o que seus funcionários } \\
\mathrm{a} \text { a dizer. }\end{array}$ & & & & & & & \\
\hline $5 \stackrel{\circ}{\circ \frac{0}{4}}$ & $\begin{array}{l}\text { preende os funcionários que } \\
\text { lam padrões éticos. }\end{array}$ & & & & & & & \\
\hline 53 & $\begin{array}{l}\text {. uma decisões justas e } \\
\text { equilibradas. }\end{array}$ & & & & & & & \\
\hline 54 & É confiável. & & & & & & & \\
\hline 55 & $\begin{array}{l}\text { Conversa sobrevalores ouética no } \\
\text { trabalho com seus funcionários. }\end{array}$ & & & & & & & \\
\hline 56 & $\begin{array}{l}\text { Dá o exemplo de como fazer as } \\
\text { coisasda maneira correta sob o } \\
\text { ponto de vista ético. }\end{array}$ & & & & & & & \\
\hline 57 & $\begin{array}{l}\text { Tem sempre em mente o que é } \\
\text { melhor para seus funcionários. }\end{array}$ & & & & & & & \\
\hline 58 & $\begin{array}{l}\text { Quando toma decisões, se } \\
\text { pergunta: "Qual acoisa certa a } \\
\text { fazer?" }\end{array}$ & & & & & & & \\
\hline
\end{tabular}


Sexo: Feminino Masc $\square$ inoIdade:

\section{Nível de instrução:}

O Médio

Superior incompleto

S Superior completo

Especialização

O Mestrado

Tempo total de experiência em vendas:

O Menos de 1 ano

De 1 à 2 anos

De 2 à 3 anos

De 3 à 4 anos

De 4 à 5 anos

De 5 à 6 anos

De 6 à 7 anos

¿ le 7 à 8 anos

ल le 8 à 9 anos

$\stackrel{\text { N }}{\underset{N}{2}}$ le 9 à 10 anos

@ po na empresa atual:

줌 Tenos de 1 ano

เo le 1 à 2 anos

ర్ల్ le 2 à 3 anos

产 le 3 à 4 anos

u le 4 à 5 anos

움 le 5 à 6 anos

le 6 à 7 anos

$\bigcirc$ De 7 à 8 anos

De 8 à 9 anos

O De 9 à 10 anos

Tempo sob a supervisão do gestor atual

Até 6 meses

De 6 meses à 1 ano

De 1 ano à 1 ano e 6 meses

De 1 ano e 6 meses à 2 anos

O Mais de dois anos 


\section{2.}

Apêndice B

Neste apêndice é possível verificar uma cópia do questionário disponibilizado aos gestores através de um link para a survey. Onde encontra-se o termo funcionário 1 , funcionário 2 etc., no questionário original existiam 
Caro participante,

Esta é uma pesquisa acadêmica que tem por objetivo estudar as impressões das pessoas em relação ao próprio trabalho e de seus subordinados. É muito importante que você preencha o questionário expressando a sua real percepção.

Todas as informações contidassão de caráter sigiloso, não sendo disponibilizadas para qualquer pessoa de sua empresa.

Parabéns! Sua colaboração permitirá o aprofundamento do conhecimento sobre a área de comportamento organizacional.

Insira aquiseu código para iniciar sua participação:

As questões abaixo dizem respeito ao desempenho de seus funcionários. Escolha a alternativa mais adequada ao desempenhode cada um individualmente.

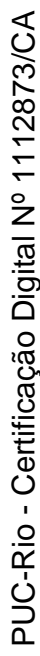

onstra desempenho superior naexecução de suas funções.

\begin{tabular}{|c|l|l|l|l|l|l|l|l|}
\cline { 3 - 8 } \multicolumn{2}{l|}{} & $\begin{array}{c}\text { Discordo } \\
\text { totalmente }\end{array}$ & $\begin{array}{c}\text { Discordo } \\
\text { em } \\
\text { grande } \\
\text { parte }\end{array}$ & $\begin{array}{c}\text { Discordo } \\
\text { em parte }\end{array}$ & $\begin{array}{c}\text { Não } \\
\text { discordo, } \\
\text { nem } \\
\text { concordo }\end{array}$ & $\begin{array}{c}\text { Concordo } \\
\text { em parte }\end{array}$ & $\begin{array}{c}\text { Concordo } \\
\text { em } \\
\text { grande } \\
\text { parte }\end{array}$ & $\begin{array}{c}\text { Concordo } \\
\text { totalmente }\end{array}$ \\
\hline 1 & Funcionário 1 & & & & & & & \\
\hline 2 & Funcionário 2 & & & & & & & \\
\hline 3 & Funcionário 3 & & & & & & & \\
\hline 4 & Funcionário 4 & & & & & & & \\
\hline 5 & Funcionário 5 & & & & & & & \\
\hline 6 & Funcionário 6 & & & & & & & \\
\hline 7 & Funcionário 7 & & & & & & & \\
\hline 8 & Funcionário 8 & & & & & & & \\
\hline 9 & Funcionário 9 & & & & & & & \\
\hline 10 & Funcionário 10 & & & & & & & \\
\hline
\end{tabular}




\section{Cumpre integralmente as responsabilidades especificadas na descrição de seu cargo.}

\begin{tabular}{|c|l|l|l|l|l|l|l|l|}
\cline { 3 - 8 } \multicolumn{2}{l|}{} & $\begin{array}{c}\text { Discordo } \\
\text { totalmente }\end{array}$ & $\begin{array}{c}\text { Discordo } \\
\text { em } \\
\text { grande } \\
\text { parte }\end{array}$ & $\begin{array}{c}\text { Discordo } \\
\text { em parte }\end{array}$ & $\begin{array}{c}\text { Não } \\
\text { discordo, } \\
\text { nem } \\
\text { concordo }\end{array}$ & $\begin{array}{c}\text { Concordo } \\
\text { em parte }\end{array}$ & $\begin{array}{c}\text { Concordo } \\
\text { em } \\
\text { grande } \\
\text { parte }\end{array}$ & $\begin{array}{c}\text { Concordo } \\
\text { totalmente }\end{array}$ \\
\hline 1 & Funcionário 1 & & & & & & & \\
\hline 2 & Funcionário 2 & & & & & & & \\
\hline 3 & Funcionário 3 & & & & & & & \\
\hline 4 & Funcionário 4 & & & & & & & \\
\hline 5 & Funcionário 5 & & & & & & & \\
\hline 6 & Funcionário 6 & & & & & & & \\
\hline 7 & Funcionário 7 & & & & & & & \\
\hline 8 & Funcionário 8 & & & & & & & \\
\hline 9 & Funcionário 9 & & & & & & & \\
\hline 10 & Funcionário 10 & & & & & & & \\
\hline
\end{tabular}

ecuta muito bem as tarefas que são esperadas dele.

\begin{tabular}{|c|l|l|l|l|l|l|l|l|}
\cline { 3 - 8 } \multicolumn{2}{l|}{} & $\begin{array}{c}\text { Discordo } \\
\text { totalmente }\end{array}$ & $\begin{array}{c}\text { Discordo } \\
\text { em } \\
\text { grande } \\
\text { parte }\end{array}$ & $\begin{array}{c}\text { Discordo } \\
\text { em parte }\end{array}$ & $\begin{array}{c}\text { Não } \\
\text { discordo, } \\
\text { nem } \\
\text { concordo }\end{array}$ & $\begin{array}{c}\text { Concordo } \\
\text { em parte }\end{array}$ & $\begin{array}{c}\text { Concordo } \\
\text { em } \\
\text { grande } \\
\text { parte }\end{array}$ & $\begin{array}{c}\text { Concordo } \\
\text { totalmente }\end{array}$ \\
\hline 1 & Funcionário 1 & & & & & & & \\
\hline 2 & Funcionário 2 & & & & & & & \\
\hline 3 & Funcionário 3 & & & & & & & \\
\hline 4 & Funcionário 4 & & & & & & & \\
\hline 5 & Funcionário 5 & & & & & & & \\
\hline 6 & Funcionário 6 & & & & & & & \\
\hline 7 & Funcionário 7 & & & & & & & \\
\hline 8 & Funcionário 8 & & & & & & & \\
\hline 9 & Funcionário 9 & & & & & & & \\
\hline 10 & Funcionário 10 & & & & & & & \\
\hline
\end{tabular}




\section{Atende totalmente aos requisitos de desempenho formais exigidos pelo trabalho.}

\begin{tabular}{|c|c|c|c|c|c|c|c|c|}
\hline & & $\begin{array}{c}\text { Discordo } \\
\text { totalmente }\end{array}$ & $\begin{array}{l}\text { Discordo } \\
\text { em } \\
\text { grande } \\
\text { parte }\end{array}$ & $\begin{array}{l}\text { Discordo } \\
\text { em parte }\end{array}$ & $\begin{array}{c}\text { Não } \\
\text { discordo, } \\
\text { nem } \\
\text { concordo }\end{array}$ & $\begin{array}{l}\text { Concordo } \\
\text { em parte }\end{array}$ & $\begin{array}{c}\text { Concordo } \\
\text { em } \\
\text { grande } \\
\text { parte }\end{array}$ & $\begin{array}{l}\text { Concordo } \\
\text { totalmente }\end{array}$ \\
\hline 1 & Funcionário 1 & & & & & & & \\
\hline 2 & Funcionário 2 & & & & & & & \\
\hline 3 & Funcionário 3 & & & & & & & \\
\hline 4 & Funcionário 4 & & & & & & & \\
\hline 5 & Funcionário 5 & & & & & & & \\
\hline 6 & Funcionário 6 & & & & & & & \\
\hline 7 & Funcionário 7 & & & & & & & \\
\hline 8 & Funcionário 8 & & & & & & & \\
\hline 9 & Funcionário 9 & & & & & & & \\
\hline 10 & Funcionário 10 & & & & & & & \\
\hline
\end{tabular}

Igaja-se com empenho nas atividades que afetam diretamente seu desempenho.

\begin{tabular}{|c|l|l|l|l|l|l|l|l|}
\cline { 3 - 8 } \multicolumn{2}{l|}{} & $\begin{array}{c}\text { Discordo } \\
\text { totalmente }\end{array}$ & $\begin{array}{c}\text { Discordo } \\
\text { em } \\
\text { grande } \\
\text { parte }\end{array}$ & $\begin{array}{c}\text { Discordo } \\
\text { em parte }\end{array}$ & $\begin{array}{c}\text { Não } \\
\text { discordo, } \\
\text { nem } \\
\text { concordo }\end{array}$ & $\begin{array}{c}\text { Concordo } \\
\text { em parte }\end{array}$ & $\begin{array}{c}\text { Concordo } \\
\text { em } \\
\text { grande } \\
\text { parte }\end{array}$ & $\begin{array}{c}\text { Concordo } \\
\text { totalmente }\end{array}$ \\
\hline 1 & Funcionário 1 & & & & & & & \\
\hline 2 & Funcionário 2 & & & & & & & \\
\hline 3 & Funcionário 3 & & & & & & & \\
\hline 4 & Funcionário 4 & & & & & & & \\
\hline 5 & Funcionário 5 & & & & & & & \\
\hline 6 & Funcionário 6 & & & & & & & \\
\hline 7 & Funcionário 7 & & & & & & & \\
\hline 8 & Funcionário 8 & & & & & & & \\
\hline 9 & Funcionário 9 & & & & & & & \\
\hline 10 & Funcionário 10 & & & & & & & \\
\hline
\end{tabular}




\section{Negligencia aspectos do trabalho que são de realização obrigatória.}

\begin{tabular}{|c|c|c|c|c|c|c|c|c|}
\hline & & $\begin{array}{c}\text { Discordo } \\
\text { totalmente }\end{array}$ & $\begin{array}{c}\text { Discordo } \\
\text { em } \\
\text { grande } \\
\text { parte }\end{array}$ & $\begin{array}{l}\text { Discordo } \\
\text { em parte }\end{array}$ & $\begin{array}{c}\text { Não } \\
\text { discordo, } \\
\text { nem } \\
\text { concordo }\end{array}$ & $\begin{array}{l}\text { Concordo } \\
\text { em parte }\end{array}$ & $\begin{array}{c}\text { Concordo } \\
\text { em } \\
\text { grande } \\
\text { parte }\end{array}$ & $\begin{array}{l}\text { Concordo } \\
\text { totalmente }\end{array}$ \\
\hline 1 & Funcionário 1 & & & & & & & \\
\hline 2 & Funcionário 2 & & & & & & & \\
\hline 3 & Funcionário 3 & & & & & & & \\
\hline 4 & Funcionário 4 & & & & & & & \\
\hline 5 & Funcionário 5 & & & & & & & \\
\hline 6 & Funcionário 6 & & & & & & & \\
\hline 7 & Funcionário 7 & & & & & & & \\
\hline 8 & Funcionário 8 & & & & & & & \\
\hline 9 & Funcionário 9 & & & & & & & \\
\hline 10 & Funcionário 10 & & & & & & & \\
\hline \multicolumn{9}{|c|}{ consegue executar tarefas essenciais. } \\
\hline & & $\begin{array}{c}\text { Discordo } \\
\text { totalmente }\end{array}$ & $\begin{array}{c}\text { Discordo } \\
\text { em } \\
\text { grande } \\
\text { parte }\end{array}$ & $\begin{array}{l}\text { Discordo } \\
\text { em parte }\end{array}$ & $\begin{array}{c}\text { Não } \\
\text { discordo, } \\
\text { nem } \\
\text { concordo }\end{array}$ & $\begin{array}{c}\text { Concordo } \\
\text { em parte }\end{array}$ & $\begin{array}{c}\text { Concordo } \\
\text { em } \\
\text { grande } \\
\text { parte }\end{array}$ & $\begin{array}{l}\text { Concordo } \\
\text { totalmente }\end{array}$ \\
\hline 1 & Funcionário 1 & & & & & & & \\
\hline 2 & Funcionário 2 & & & & & & & \\
\hline 3 & Funcionário 3 & & & & & & & \\
\hline 4 & Funcionário 4 & & & & & & & \\
\hline 5 & Funcionário 5 & & & & & & & \\
\hline 6 & Funcionário 6 & & & & & & & \\
\hline 7 & Funcionário 7 & & & & & & & \\
\hline 8 & Funcionário 8 & & & & & & & \\
\hline 9 & Funcionário 9 & & & & & & & \\
\hline 10 & Funcionário 10 & & & & & & & \\
\hline
\end{tabular}

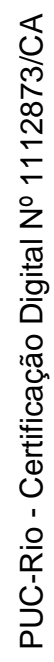


As questões abaixo referem-se à você.

Sexo: Feminino Masc $\square$ inoIdade:

\section{Nível de instrução:}

O Médio

O Superior incompleto

S Superior completo

Especialização

O Mestrado

Tempo no cargo de liderança na empresa atual:

O Menos de 1 ano

De 1 à 2 anos

De 2 à 3 anos

¿ le 3 à 4 anos

ल 1 e 4 à 5 anos

$\stackrel{\text { ํ }}{=}$ le 5 à 6 anos

$\underset{\text { à }}{\text { I. }}$ le 6 à 7 anos

종 7 à 8 anos

: $\quad$ le 8 à 9 anos

i⿱ ) 9 à 10 anos

旁

I Tenos de 1 ano

음 le 1 à 2 anos

م le 2 à 3 anos

De 3 à 4 anos

De 4 à 5 anos

De 5 à 6 anos

De 6 à 7 anos

De 7 à 8 anos

De 8 à 9 anos

O De 9 à 10 anos 
As questões àseguir referem-se à você. Para cada questão, escolha a alternativa que considera mais adequada, lembrando que não existe uma resposta certa e que nenhuma pessoa de sua empresa terá acesso às suas respostas.

\begin{tabular}{|c|c|c|c|c|c|c|c|}
\hline & & $\begin{array}{l}\text { Discordo } \\
\text { totalmente }\end{array}$ & $\begin{array}{l}\text { Discordo } \\
\text { em } \\
\text { grande } \\
\text { parte }\end{array}$ & $\begin{array}{l}\text { Discordo } \\
\text { em parte }\end{array}$ & $\begin{array}{l}\text { Concordo } \\
\text { em parte }\end{array}$ & $\begin{array}{c}\text { Concordo } \\
\text { em } \\
\text { grande } \\
\text { parte }\end{array}$ & $\begin{array}{l}\text { Concordo } \\
\text { totalmente }\end{array}$ \\
\hline 1 & $\begin{array}{l}\text { Eu nunca atravessoa rua sem } \\
\text { olhar para os dois lados. }\end{array}$ & & & & & & \\
\hline 2 & $\begin{array}{l}\text { Eu nunca tive inveja de } \\
\text { ninguém. }\end{array}$ & & & & & & \\
\hline 3 & Não tenho vergonha de nada. & & & & & & \\
\hline 4 & Eu nunca odiei ninguém. & & & & & & \\
\hline 5 & Eu nunca peço desculpas. & & & & & & \\
\hline 6 & $\begin{array}{l}\text { As vezes eu dirijo acima do } \\
\text { limite de velocidade. }\end{array}$ & & & & & & \\
\hline 7 & $\begin{array}{l}\text { Eu gosto de todas as pessoas } \\
\text { que eu conheço. }\end{array}$ & & & & & & \\
\hline 8 & $\begin{array}{l}\text { Eu sempre devolvo dinheiro } \\
\text { quando encontro. }\end{array}$ & & & & & & \\
\hline 9 & $\begin{array}{l}\text { Eu sempre atravesso na faixa } \\
\text { de pedestres. }\end{array}$ & & & & & & \\
\hline 10 & $\begin{array}{l}\text { Alguns dias eu preferiria ficar } \\
\text { na cama. }\end{array}$ & & & & & & \\
\hline
\end{tabular}

